\title{
ESTUDOS SOBRE A ABSORÇÃO DE ÁGUA E O DESEMPENHO DE SEMENTES DE SOJA
}

\section{Claudia Antonia Vieira Rossetto}

Tese apresentada à Escola Superior de Agricultura "Luiz de Queiroz", da Universidade de São Paulo, para obtenção do título de Doutor em Agronomia.

Área de Concentração: Fitotecnia.

PIRAC ICA B A

Estado de São Paulo - Brasil

Outubro -1995 
Dados Internaciona is de Caralogaçăo na fuelidução (CIP)

Divisão de Biblioteca e Doclinentaçăo - CAMPUS :Li: DE QUEIrOZ"/USF

Rossetto, Claudia Antonia Vieira

Estudos sobre a absorção de água e o desempenho de sementes de soja. Piracicaba, 1995.

i44p. ilus.

Tese - ESALC

Bibliografia.

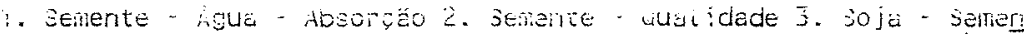
ce - Quai idade I. Escola superior de igricutcura Luiz de Queiroz, Pira cicaba

CDD $\quad 633.34$

ó3i.521 


\title{
ESTUDOS SOBRE A ABSORÇÃO DE ÁGUA E O DESEMPENHO DE SEMENTES DE SOJA
}

\author{
CLAUDIA ANTONIA VIEIRA ROSSETTO
}

Aprovada em 13.12.1995

Comissão julgadora:

Prof. Dr. Walter Rodrigues da Silva (Orientador Substituto) ESALQ/USP

Dra. Ana Dionisia da Luz Coelho Novembre ESALQ/USP

Prof. Dr. Francisco Ferraz de Toledo ESALQ/USP

Prof. Dr. João Nakagawa FCA/UNESP

Profa. Dra. Denise Cunha Fernandes dos Sintos Dias UFV

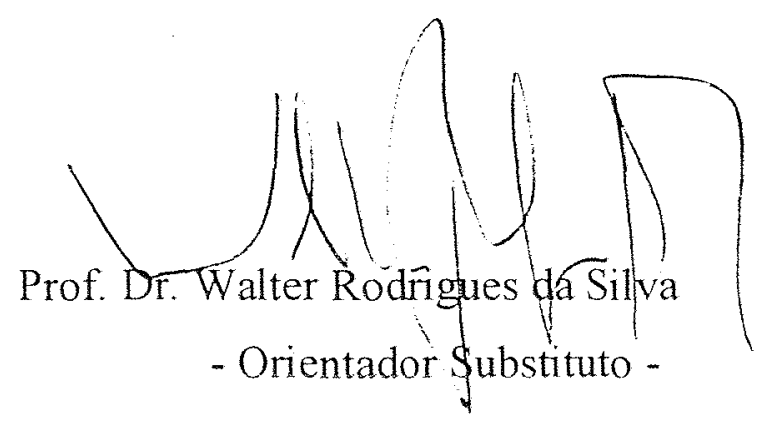


Aos meus pais Antonio José e Maria Amélia Ao Victor Augustus 


\section{AGRADECIMENTOS}

Ao Professor Julio Marcos Filho pelo apoio e segura orientação.

Ao Professor Walter Rodrigues da Silva pela valiosa colaboração.

Aos Professores Francisco Ferraz de Toledo, Gil Miguel de Sousa Câmara, Keigo Minami, Luiz Eduardo Gutierrez, Maria Cristima Stolf Nogueira, Paulo Leonel Libardi, Quirino Augusto Carmello, Raul Machado Neto, Ricardo Victória Filho, Sérgio Oliveira Moraes e Sílvio Moure Cícero pela assistência no transcorrer do trabalho.

As Engenheiras Agrônomas Dra. Ana Dionisia da Luz Coelho Novembre e Mestre Helena Maria Pescarin Chamma pelo auxílio constante.

Aos funcionários do Departamento de Agricultura Adriana Tomazzello Gimenes, Carlos Adversi Carlet, Hodair Banzatto Junior, Ilze Helena das Neves, Jair Vitório Arthur, José Laércio Favarin, João Batista Bigelli, João Elias Jabur Filho e Maria Aparecida Soledade pelos serviços prestados.

Às Bibliotecárias Eliana Maria Garcia Sabino e Katia Maria de Andrade Ferraz pela colaboração prestada.

Ao Conselho Nacional de Desenvolvimento Cientifico e Tecnológico pela concessão da Bolsa de Estudos por um ano e à Fundação de Amparo à Pesquisa do Estado de São Paulo pelo suporte financeiro para a realização do projeto e pela bolsa de estudo concedida por vinte meses.

Ao Serviço de Produção de Sementes Básicas do Instituto Agronômico do Estado de São Paulo (IAC). em especial à Dra. Priscila Fratin Medina e ao Dr. Luiz Fernandes Razera, pelo fornecimento das sementes utilizadas na pesquisa. 


\section{SUMÁRIO}

Página

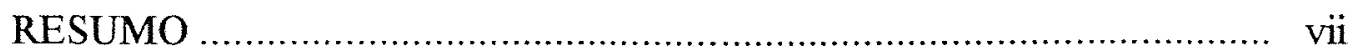

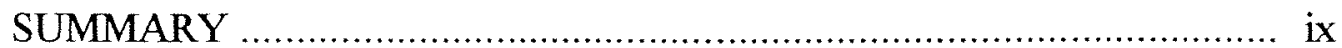

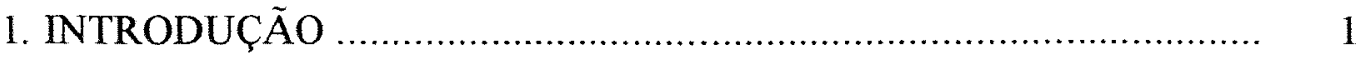

2. REVISÃO DE LITERATURA …................................................... 3

2.1. Hidratação e o processo de germinação das sementes ...................... 3

2.1.1. Velocidade de absorção de água .......................................... 7

2.1.2. Gradiente hídrico ......................................................... 10

2.2. Reparo das membranas celulares .............................................. 14

2.3. Danos por embebição................................................................... 18

2.4. Injúrias por baixas temperaturas .................................................. 23

2.5. Manifestações das alterações das membranas .................................. 25

3. MATERIAL E MÉTODOS …................................................... 30

3. l. Obtenção da variabilidade entre lotes .......................................... 30

3.2. Caracterização dos lotes ............................................................ 31

3.2.1. Teste de germinação ....................................................... 31

3.2.2. Primeira contagem de germinação ..................................... 32

3.2.3. Condutividade elétrica ................................................. 32

3.2.4. Envelhecimento acelerado .............................................. 32

3.2.5. Teste de tetrazólio ........................................................ 33

3.2.6. Grau de umidade .......................................................... 34

3.2.7. Peso de mil sementes .................................................. 34

3.3. Obtenção de sementes com diferentes teores de água ..................... 34

3.4. Caracterização das sementes após umedecimento artificial ............. 35

3.5. Avaliação da absorção de água .................................................... 35

3.5.1. Marcha de absorção de água ............................................. 37

3.5.2. Emissão de raiz primária .................................................. 37

3.5.3. Avaliação da proporção de sementes intumescidas ............... 38 
3.5.4. Avaliação dos danos por embebição .................................... 38

3.5.4.1. Liberação de íons ............................................... 38

3.5.4.2. Deterioração por "umidade" .................................. 39

3.6. Avaliação da germinação das sementes ......................................... 40

3.7. Avaliação da emergência das plântulas ........................................... 41

3.7.1. Preparo das caixas para a instalação ................................... 42

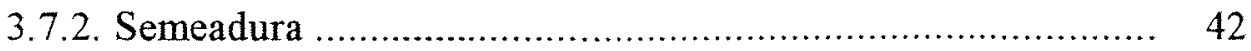

3.8. Procedimento Estatístico ............................................................ 46

4. RESULTADOS E DISCUSSÃO …............................................. 50

4.1. Caracterização dos lotes ......................................................... 50

4.2. Caracterização das sementes após umedecimento artificial ............. 54

4.3. Avaliação da absorção de água, sob diferentes potenciais hídricos,

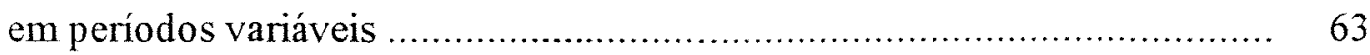

4.3.1. Marcha de absorção de água .............................................. 64

4.3.2. Emissão de raiz primária ….............................................. 73

4.3.3. Avaliação da proporção de sementes intumescidas ............... 81

4.3.4. Avaliação dos danos por embebição .................................... 84

4.3.4.1. Liberação de íons ................................................. 84

4.3.4.2. Deterioração por "umidade" ................................. 94

4.4. Relações entre o teor de água e a germinação das sementes sob a influência de diferentes potenciais hídricos ........................................ 106

4.5. Relações entre o teor de água e a emergência das plântulas sob a influência de diferentes potenciais hídricos ............................................ 119

4.6. Considerações gerais ............................................................ 126

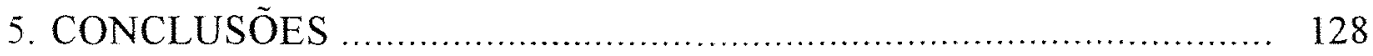

REFERÈNCIAS BIBLIOGRÁFICAS _......................................... 129 


\title{
ESTUDOS SOBRE A ABSORÇÃO DE ÁGUA E O DESEMPENHO DE SEMENTES DE SOJA
}

\author{
Autor: CLÁUDIA ANTONIA VIEIRA ROSSETTO \\ Orientador: Prof. Dr. JULIO MARCOS FILHO
}

\section{RESUMO}

A pesquisa, conduzida no Laboratório de Análise de Sementes da Escola Superior de Agricultura "Luiz de Queiroz", da Universidade de São Paulo, em Piracicaba, Estado de São Paulo, teve por objetivo estudar as relações entre o teor inicial de água e a qualidade fisiológica das sementes, o potencial hídrico do substrato e o comportamento da soja (Glycine max (L.) Merrill) durante a absorção de água para a germinação. Para tanto, foram utilizados três lotes de sementes do cultivar IAC-15, cuja variabilidade foi obtida pela aplicação do envelhecimento artificial.

Visando a obtenção de sementes com 110 e $130 \mathrm{~g}$ de água $/ \mathrm{kg}$, além das sementes que apresentavam-se com o teor inicial de água de $90 \mathrm{~g} / \mathrm{kg}$, para cada lote, foram adotados procedimentos para o umedecimento artificial. Após esta etapa, foi realizada a avaliação da qualidade fisiológica dessas sementes, através dos testes de germinação, grau de umidade, primeira contagem, envelhecimento acelerado, condutividade elétrica e tetrazólio.

Para cada lote, foram verificadas as marchas de absorção de água e efetuadas avaliações da proporção de sementes intumescidas, da emissão de raiz primária e da ocorrência de danos por embebição (liberação de íons e deterioração por "umidade"). Assim, sementes com 90, 110 e $130 \mathrm{~g}$ de água $/ \mathrm{kg}$ foram colocadas para embeber entre camadas de folhas de papel Germitest, umedecidas com soluções de 
diferentes concentrações de Polietilenoglicol (PEG 6000) que simulavam os potenciais hídricos de $-0,04 ;-0,10 ;-0,20$ e -0,40 MPa.

Paralelamente, para cada lote, as sementes com diferentes graus de umidade também foram colocadas para germinar sob os mesmos potenciais hídricos citados, em dois tipos de substratos: papel Germitest e terra. O umedecimento do papel foi realizado com soluções de polietilenoglicol e, o da terra adicionando-se volumes de água correspondentes aos potenciais hídricos desejados. Em terra, determinaram-se a porcentagem de emergência de plântulas e o índice de velocidade de emergência de plântulas. Em papel, avaliaram-se a porcentagem de sementes que emitiram raiz primária aos 3 dias da instalação, o vigor através da primeira contagem de plântulas normais do teste de germinação aos 5 dias da instalação e a porcentagem de germinação total aos 7 dias da instalação.

A análise dos dados e a interpretação dos resultados permitiram as seguintes conclusões: 1. Existe efeito da qualidade fisiológica das sementes no desempenho sob influência de potenciais hídricos deficitários no substrato;2. Para os potenciais hídricos estudados, o aumento do teor inicial de água das sementes contribui para a diminuição da velocidade de absorção de água e permite atenuar os danos por embebição, podendo favorecer a germinação e a emergência de plântulas, em função da qualidade fisiológica das sementes; 3. A germinação e a emergência estão diretamente relacionadas à disponibilidade hídrica do substrato. 


\title{
RELATIONSHIP OF SEED IMBIBITION AND THE GERMINATION PROCESS IN SOYBEAN SEEDS
}

\author{
Author: CLAUDIA ANTONIA VIEIRA ROSSETTO \\ Adviser: Prof. Dr. JULIO MARCOS FILHO
}

\section{SUMMARY}

The research carried out at the Laboratory of Seed Analyse of the Escola Superior de Agricultura 'Luiz de Queiroz', University of São Paulo, Brazil, had the main purpose of studying the relations among moisture content, seed physiological quality and water availability on the performance of soybean seed throughout the water uptake to germination. Seeds from three soybean (Glycine max (L.) Merrill) lots IAC-15, with differents levels of physiological quality, were used.

Proceedings for moistening of seeds of three lots were accomplished basing in preliminary tests. Thus, were obtained samples with 110 e $130 \mathrm{~g}$ water.kg fresh weight -1 , moreover samples with the original water content, represented by $90 \mathrm{~g}$ water.kg fresh weight ${ }^{-1}$ The physiological quality of seeds was evaluated after this, throughout of germination, seed moisture, first count, electric conductivity, accelerated aging and tetrazolium tests.

For each lot, was realized the establishment of rate of water uptake and were measured the size modifications of the hydrated seeds, the radicle emission and the imbibition damage after different periods of time. Thus, seeds with 90,110 e $130 \mathrm{~g}$ water.kg fresh, were setted between layers of paper germination towels, moistened with polyethylene glycol solution (PEG 6000), simulating the water potentials of $-0.04,-0.10$, -0.20 e $-0.40 \mathrm{MPa}$.

On the other hand, the seeds of the each lot, with 90,110 e $130 \mathrm{~g}$ water.kg were setted for germinate under differents water potentials at soil and at paper towel 
substrate. The moistening of paper towel was realized with polyethylene glycol solution which represented potencials of $-0.04,-0.10,-0.20$ e $-0.40 \mathrm{MPa}$. The moistening of soil was based in curve of retention of water of soil throughout of addition of corresponding volume of water at the similar water potencials to used at the paper. At soil were evaluated speed and percentage seedling emergence and at paper, were evaluated radicle protrusion at three days after instalation, normal seedling at five days, and germination percentages at the seven days after seeding.

The data analysis and the results interpretation led to the following conclusions: 1. There is relation among physiological quality and performance of seeds during the germination under different water potential of substratum; 2. To the water potentials studied, the increase of water content of seeds resulted in decreased water uptake rate and reduced the imbibition damage, eventually increasing the germination and seedling emergence; 3 . The germination and seedling emergence were directly related to the water availability of substratum. 


\section{INTRODUÇÃO}

O estabelecimento das plântulas, visando a obtenção de população adequada, constitui a base para altos rendimentos agrícolas, em culturas de expressão econômica. Desta maneira, a germinação das sementes representa a meta prioritária dentro do processo de produção.

Entre outras causas, a emergência das plântulas é reflexo da qualidade fisiológica da semente. Tanto assim que, a responsabilidade das falhas de germinação, ou mesmo a redução de sua velocidade, frequentemente são atribuídas ao baixo vigor, associado ao processo de deterioração. No entanto, a análise mais detalhada do problema permite a identificação de vários fatores do ambiente capazes de afetar positiva ou negativamente a germinação; entre eles, certamente, a disponibilidade de água é fator importante.

A germinação, ou seja. a emissão da raiz primária e o crescimento da plàntula requer energia e material de reserva para a síntese de novos tecidos. Tanto um como o outro tornam-se disponíveis através de processos metabólicos catalisados por enzimas nos tecidos das sementes. Portanto, a água é essencial ao metabolismo celular durante a germinação pelo menos por très motivos: para a atividade enzimática, para a solubilização e transporte dos reagentes e como reagente em si, principalmente, na digestão hidrolítica das substâncias de reserva armazenadas na semente.

As etapas iniciais da hidratação da semente, um processo conhecido como embebição, caracterizam um período em que a semente transita de um estado latente, ou seja, de baixa atividade metabólica, para outro que possibilita a intensificação de sua capacidade de responder a estímulos do ambiente e o desenvolvimento do embrião. Acredita-se, conforme considerou VERTUCCI (1989), que esta transição envolve a 
reorganização dos constituintes celulares; por este motivo, à medida em que se reidrata, a semente se torna particularmente sensível às variações de temperatura.

Assim, a eficiência de reorganização dos constituintes celulares depende do teor de água da semente, da temperatura do ambiente e da velocidade de absorção de água, que também depende da estrutura, da composição química e da qualidade fisiológica da semente. Em condições de baixa disponibilidade hídrica, a absorção de água e consequentemente, o processo de germinação se tornam lentos e, desta forma, as sementes liberam exsudatos e permanecem expostas ao ataque de microrganismos durante maior período de tempo. Por outro lado, sementes secas semeadas em solo muito úmido podem absorver água rapidamente, provocando danos às membranas em reorganização e intensificando a liberação de solutos, com consequentes prejuizos à germinação. Esta liberação é ampliada com a intensificação da deterioração das sementes.

A literatura contém referências sobre a ocorrência dos danos por embebição em sementes de diferentes espécies e observações quanto aos efeitos do teor de água das sementes sem, contudo, elucidar as dimensões. São, também, relativamente frequentes os estudos sobre a importância do potencial hídrico do substrato para a germinação. No entanto, são tão escassas quanto necessárias as informações que associem os danos por embebição, teor de água das sementes no momento da semeadura e potencial hídrico do substrato, envolvendo, também, a qualidade fisiológica das sementes.

Considerando-se a importância econômica e a permeabilidade do tegumento das sementes, o presente trabalho objetivou estudar as relações entre o teor inicial de água e a qualidade fisiológica das sementes, o potencial hídrico do substrato e o comportamento das sementes durante a absorção de água para a germinação. 


\section{REVISÃO BIBLIOGRÁFICA}

\subsection{Hidratação e o processo de germinação das sementes}

A germinação das sementes, constituida por uma sequência de eventos metabólicos que resulta na transformação de um embrião em uma plântula, é um fenômeno biológico cuja ocorrência é determinada por um conjunto de condições ambientais favoráveis (MARCOS FLLHO, 1986). Neste conjunto, a disponibilidade de água é fundamental.

A água não é apenas o agente iniciador da germinação, como também está envolvida, direta ou indiretamente, em todas as demais etapas do metabolismo subsequente. Sua participação é decisiva nas reações enzimáticas, na solubilização e transporte de metabólitos e, como reagente. na digestão hidrolítica de proteínas, carboidratos e lipídios de reserva da semente (CARVALHO \& NAKAGAWA, 1988; WOODSTOCK, 1988). Para VERTUCCI \& LEOPOLD (1987), na ausência de água, a taxa de difusão de solutos permanece muito reduzida e, consequentemente afeta 0 movimento intracelular de proteínas essenciais para as atividades catalíticas. Além disso, o efeito da água sobre a estrutura de fosfolipídios exerce importante papel na eficiência da permeabilidade das membranas.

A absorção de água, constitui-se, portanto, no primeiro passo de toda uma sequência de eventos que, no caso de sementes viáveis e não dormentes, culmina com a emissão da raiz primária (TOLEDO \& MARCOS FLLHO, 1977).

O processo de absorção de água pelas sementes obedece a um padrão trifásico (BEWLEY \& BLACK, 1985); na primeira fase (I), também chamada de embebição, o menor potencial hídrico da semente em relação ao do substrato, favorece 
um rápido fluxo de água no sentido substrato semente e, a absorção pode aumentar exponencialmente dependendo do grau de permeabilidade do tegumento. Portanto, é consequência das forças mátricas das paredes das células e dos constituientes da semente. Nesta fase, a embebição independe de atividade metabólica e, verifica-se, também, em sementes mortas e dormentes, desde que a dormência não decorra da impermeabilidade do tegumento. Além disso, pode ocorrer sob condições anaeróbicas e sob baixa temperatura, porém, de maneira mais lenta (MARCOS FILHO, 1986).

O final da fase I é marcado pela aproximação do nível do potencial hídrico da semente ao do substrato. Inicia-se, então a fase II, caracterizada por uma drástica redução da velocidade de absorção de água, que se torna consideravelmente menor que a apresentada na fase I (LABOURIAU, 1983). Nesta fase, ocorre degradação das substâncias de reserva para que essas possam ser transportadas para o tecido meristemático. As sementes mortas e dormentes mantém o nível de hidratação atingido nesta fase e, ao contrário das sementes viáveis e não dormentes, não alcançam a fase subsequente (BEWLEY \& BLACK, 1985).

O início da terceira fase (III) é marcado pela emissão da raiz primária, sendo de ocorrência restrita às sementes viáveis e não dormentes. Esta fase caracteriza-se por intensa atividade metabólica e com uma significativa elevação da velocidade de absorção de água pela semente, para a qual a raiz primária recém emergida contribui de maneira decisiva (BEWLEY \& BLACK 1985). Portanto, para que haja início visível da germinação, a semente deve atingir um determinado teor de água, que no caso de sementes de soja, é de no mínimo, 500 a $550 \mathrm{~g}$ de água $/ \mathrm{kg}$ de sementes úmidas conforme HUNTER \& ERICKSON (1952). Segundo ARMSTRONG \& Mc DONALD (1992), a emissão da raiz primária ocorre após 21 horas de embebição, quando o eixo embrionário atinge $650 \mathrm{~g}$ de água $/ \mathrm{kg}$ de sementes úmidas e os cotilédones, assim como a semente toda, atingem $550 \mathrm{~g}$ de água/kg. Para McDONALD Jr.et al. (1988 a,b), a germinação ocorre após 48 horas de embebição sob temperatura alternada de 20 e $30^{\circ} \mathrm{C}$, quando o eixo embrionário de sementes de soja apresenta cerca de $800 \mathrm{~g}$ de água/kg de sementes úmidas e a semente como um todo apresenta de 550 a $600 \mathrm{~g}$ de água $/ \mathrm{kg}$. Nesta fase III, as sementes, que são tolerantes à desidratação na maturidade e durante as primeiras 
etapas da germinação, tornam-se suscetíveis às injúrias por desidratação (DELTOUR \& JACQMARD, 1974; HEGARTY, 1977 e BRADFORD, 1986).

A duração de cada uma das três fases de absorção de água é determinada por várias características das sementes, tais como, composição química, tamanho, permeabilidade do tegumento e, pelas condições ambientais que prevalecem durante o período de absorção de água (MARCOS FILHO, 1986). O padrão trifásico, descrito por BEWLEY \& BLACK (1985), sugere que apenas a fase III da absorção de água está relacionada à viabilidade das sementes pois, a fase inicial, chamada embebição, constitui um fenômeno essencialmente fisico.

A entrada de água nas sementes é um momento crítico para a germinação, pois provoca o intumescimento das partículas coloidais e, consequentemente, resulta no aumento do volume de toda a semente, tomando o tegumento mais permeável ao oxigennio e ao dióxido de carbono e, desta maneira ocasiona o rompimento deste tegumento, favorecendo ainda mais as trocas gasosas do embrião com o ambiente e facilitando a emergência da raiz primária (MAYER \& POLJAKOFF-MAYBER, 1975).

O grau de intumescimento da semente é um reflexo da composição química de suas estruturas, assim, as proteínas, que constituem a principal fração coloidal das sementes, são os componentes de maior importância associada à absorção de água (WOODSTOCK, 1988); já, a contribuição dada pela celulose e substâncias pécticas é pequena (CARDWELL, 1984) e a do amido, nenhuma (MAYBER \& POLJAKOFFMAYBER, 1975). Por esta razão, MARCOS FLLHO (1986) relatou que a grande absorção de água pela semente de soja se justifica pelo volume do embrião e sua composição química, onde predominam as proteínas de reserva.

As mudanças na velocidade de entrada de água nas sementes sugerem que há duas fases de absorção de água: uma fase de umedecimento inicial e uma subsequente de fluxo bidraúlico. Na fase de umedecimento, o teor de água é menor que $230 \mathrm{~g} / \mathrm{kg} \mathrm{de}$ sementes, coincidindo com o teor onde as sementes são mais sensiveis aos danos por embebição (VERTUCCI \& LEOPOLD, 1983; VERTUCCI \& LEOPOLD, 1984; VERTUCCI, 1989). 
Ao entrar na semente, a água estabelece ligação com as partículas coloidais, principalmente, com as dispersas nos tecidos de reserva, ligação esta que se faz de diferentes formas, em função do nível em que se estabelece e nas quais agem diferentes tipos de forças (CARVALHO, 1994). Na soja, a água está presa até um teor de aproximadamente $26 \mathrm{~g}$ de água/kg de sementes; acima desse valor é considerada como "livre"; abaixo desse valor, as moléculas de água, em função da união com as partículas coloidais, adquirem uma configuração estrutural diferente daquela de seu estado livre (VERTUCCI, 1989).

Segundo VERTUCCI (1992), as interações entre a superficie das partículas coloidais e a água podem ser descritas através de um modelo para proteínas, em que a proteína é uma coleção de posições de adsorção, com várias afinidades por água, de tal forma que, quando uma proteína é hidratada, a água é retida nas posições hifrofilicas. No entanto, as interações entre a água e a superficie das proteínas variam, dependendo da região da macromolécula e, assim, as propriedades da água também variam à medida em que a macromólecula vai se hidratando.

Em trabalhos mais recentes, considera-se que nas sementes existem cinco tipos de água; tipos esses definidos pela força com que a água se encontra ligada à superficie de macromoléculas (VERTUCCI, 1992). No tipo 1, está quimicamente unida às macromoléculas através de ligações iônicas, num processo denominado "quimisorção", ou seja, a água está presente em tecidos com menos de $74 \mathrm{~g}$ de água/kg de sementes e, portanto, considerada água estrutural. Quando as sementes são intumescidas até atingir 91 a $180 \mathrm{~g}$ de água $/ \mathrm{kg}$, tem-se a água denominada tipo 2 , sendo que a partir desse tipo, a água passa a ter um papel de solvente e a energia de ligação com a macromolécula é menor que a do tipo 1. Apenas, após o umedecimento adicional dos tecidos, há uma indicação da presença de água chamada tipo 3, que se associa à porção hidrofilica e sua presença assinala alterações nos lipídios das membranas. Além disso, as do tipo 4 e 5 se mostram como água que preenche pequenos poros e água que compõe a solução das células, respectivamente, sendo que estes dois últimos tipos tem propriedades muito semelhantes à da água em uma solução muito diluida. 
As relações entre atrividades metabólicas e o teor de água das sementes não estão perfeitamente definidas, pois na literatura, é mais comum a relação com períodos de embebição e não com os teores de água, ou seja, o acréscimo da atividade da lipoxidase em sementes de soja foi observada um minuto após o início da embebição; a dos mitocôndrios, após horas, sem referência aos teores de água correspondentes (VERTUCCI \& LEOPOLD,1987). Entretanto, VERTUCCI (1989) relatou que há uma relação entre os tipos de água e atividade metabólica, pois no nível de água “ tipo 4", a síntese de proteínas e os mecanismos de reparo de cada ácido nucléico são ativados permitindo a germinação.

\subsubsection{Velocidade de absorção de água}

A velocidade da absorção de água é crítica para a subsequente germinação e depende da permeabilidade do tegumento, da estrutura, da composição química e do teor de água das sementes (VERTUCCI, 1989), da disponibilidade de água no estado líquido ou gasoso (OBENDORF \& HOBBS, 1970; VERTUCCI \& LEOPOLD, 1983), da pressão osmótica da água ou da solução que umedece o substrato, do tempo de exposição ao ambiente úmido, da temperatura (COPELAND, 1976), da área de contato da semente com o substrato (LeDEUNFF. 1089) e da qualidade fisiológica da semente (TOLEDO \& MARCOS FILHO, 1977).

O tegumento das sementes tem sido considerado como uma barreira à entrada de água (WOODSTOCK, 1988), de tal forma que suas características estão relacionadas à velocidade com que ocorre a absorção. Toda semente madura é envolvida por uma cobertura protetora que em grande número de espécies, é constituida por duas camadas, a testa e a tegma, originadas dos dois integumentos do óvulo, respectivamente, a primina e a secundina (TOLEDO \& MARCOS FLHO, 1977).

Inicialmente, o tegumento atua como elemento retardador da absorção de água, passando, posteriormente, a contribuir significativamente no auxílio à entrada de água no interior das semente, permitindo que ambos os cotilédones se hidratem de modo uniforme. Assim, a grande capacidade de absorção de água pelo tegumento equivale a 3,8 
vezes o peso da semente, de forma que o tegumento desempenha o papel de reservatório de água para as etapas iniciais da germinação, contribuindo para a retenção da umidade interna da semente e protegendo-a de eventual secagem após a embebição (Mc DONALD Jr. et al., 1988a).

A permeabilidade do tegumento das sementes de soja é determinada, em grande parte, pela presença de poros, cuja forma, tamanho e frequência por unidade de superficie são variáveis de acordo com o genótipo e condicionam o grau de controle sobre o processo de absorção de água (CALERO et al., 1981). Assim, no caso específico da soja, apesar do tegumento com poros geralmente se mostrarem permeáveis e a ausência destas fendas naturais estar associada à impermeabilidade, a frequência de poros por unidade de superfície do tegumento não é o único fator regulador da absorção de água pela semente, pois evidências experimentais indicam que as sementes que menos absorvem água são aquelas cujos poros são pequenos, alongados e cuja epiderme apresenta uma densa camada cerosa (YAKLICH et al., 1984).

Da mesma forma, a integridade fisica do tegumento é muito importante; esta condição tem controle sobre a velocidade de absorção e, consequentemente, sobre a germinação (LARSON, 1968; POWELL \& MATTHEWS, 1978; SIMON \& RAJAHARUN, 1972; DUKE \& KAFEFUDA, 1981). As sementes, cujo tegumento é danificado, apresentando fendas, rachaduras e orificios, tendem a se caracterizar pela menor viabilidade e vigor (VIEIRA et al., 1982).

Enquanto o tegumento da semente tem sido discutido em termos de permeabilidade, outras partes da semente podem diferir quanto à velocidade de entrada de água, de tal forma que o eixo embrionário absorve mais rapidamente que o tegumento da semente de soja (BEWLEY \& BLACK, 1985). Dentro deste contexto, POWELL \& MATTHEWS (1978) e DUKE et al. (1983) também observaram que, quando os tegumentos são removidos ou danificados, os cotilédones absorvem água mais rapidamente.

MARCOS FLLHO (1986) sugeriu que não apenas as sementes com maior volume embrionário em relação ao endosperma e com predominância de proteína nos tecidos de reserva absorvem água com maior rapidez, como a absorção é igualmente 
rápida nas sementes imaturas e nas mais deterioradas, em virtude da maior permeabilidade do tegumento e da desorganização dos sistemas de membranas celulares, verificada nessas situações.

A idéia segundo a qual a velocidade de entrada de água na semente depende do vigor da semente é controvertida. As condições de envelhecimento de sementes de feijão resultam na polimerização de substâncias pécticas e em outras mudanças estruturais, mas não afetam a velocidade de embebição, segundo VINDIOLA et al. (1986) e HOHLBERG \& STANLEY (1987).

Da mesma forma, não foi constatada nenhuma diferença na velocidade de absorção de água em sementes de soja envelhecidas artificialmente ou não, quando foram intumescidas, mas somente um pequeno aumento na atividade das enzimas das sementes que não foram envelhecidas, levando a concluir que a entrada de água nas sementes é limitada quando as membranas estão bem estruturadas (LEOPOLD, 1980).

Outros pesquisadores buscaram determinar prováveis relações entre aspectos de absorção de água pelas sementes e qualidade fisiológica. VIEIRA et al. (1982) verificaram embebição inicial mais rápida em sementes de soja com deterioração avançada. Porém, McDONALD Jr. et al. (1988b) constataram idêntico padrão de absorção de água pelos cotilédones de sementes de soja com diferentes qualidades fisiológicas. Para WOODSTOCK (1988), não há unanimidade nas opiniões referentes à associação entre a qualidade fisiológica e a rapidez de absorção de água pelas sementes, pois é dificil individualizar os efeitos do tamanho da semente, permeabilidade do sistema de membranas celulares e composição química, que frequentemente interagem com outros fatores.

Em relação ao teor de água inicial das sementes, PARRISH \& LEOPOLD (1977) relataram que a absorção varia diretamente com o teor de água dos tecidos. Além disso, a velocidade de embebição é maior quando as sementes apresentam menor teor de água inicial, ou seja, sementes com teor de água inicial abaixo de $57 \mathrm{~g} / \mathrm{kg}$ de sementes úmidas absorvem água de maneira rápida e com teor de água acima de $142 \mathrm{~g} / \mathrm{kg}$ absorvem água de maneira lenta (OBENDORF \& HOBBS, 1970; HOBBS \& OBENDORF, 1972; ASHWORTH \& OBENDORF, 1980). 
Para HOBBS \& OBENDORF (1972), a absorção de água é mais afetada pela temperatura que pelo teor de água das sementes, sendo que o aumento do teor de água das sementes pode facilitar o desempenho das sementes em solo sob condição de baixa temperatura. Assim, nesta condição, a embebição ocorre mais lentamente, pois há uma correlação entre os efeitos da temperatura, da velocidade de embebição e da viscosidade da água (MURPHY \& NOLAND, 1982). Além disso, VERTUCCI \& LEOPOLD (1983) relataram que sob condição de baixa temperatura, ocorre uma lenta embebição devido ao aumento da viscosidade da água, principalmente quando as sementes estão com teor de água acima de $40 \mathrm{~g}$ de água $/ \mathrm{kg}$ de sementes úmidas.

Há uma velocidade ótima de absorção de água, sendo que se a absorção for muito lenta, a germinação é reduzida, talvez por causa da invasão de fungos ou aceleração da deterioração, e se for rápida, as sementes são sujeitas aos danos por embebição. A rápida embebição ocasiona uma hidratação diferencial das proteínas dos tecidos e, consequentemente, ocasiona ruptura dos cotilédones que provoca a perda de exsudatos orgânicos, favorecendo o ataque de microrganismos (OBENDORF \& HOBBS, 1972).

\subsubsection{Gradiente hídrico}

$\mathrm{O}$ movimento de água para o interior da semente é devido tanto ao processo de capilaridade ou de fluxo hidráulico, expresso em termos de potencial hídrico, quanto ao processo de difusão, expresso em termos de concentração, e assim, ocorre do sentido da menor concentração ou maior potencial hídrico para a maior concentração ou menor potencial hídrico (VERTUCCI, 1989).

De acordo com VERTUCCI (1989), tanto a lei de difusão como a de fluxo hidráulico insaturado de água estabelecem que a velocidade de absorção de água é controlada por um gradiente, de tal forma que quando a água é amplamente fornecida, ela será absorvida pela semente desde que os tegumentos sejam permeáveis. A absorção de água prevê uma fase de umedecimento inicial e uma subsequente de fluxo hidráulico. 
À medida em que as sementes absorvem água, o seu potencial hídrico se eleva, diminuindo o gradiente existente com o solo. Com isso, o fluxo hidráulico da semente aumenta e tende a se igualar ao do solo (SHIOGA, 1990).

O potencial hídrico total da semente é composto por três componentes, ou seja, pelo potencial osmótico, pelo potencial mátrico e pela pressão de turgescência. $O$ potencial osmótico é função da concentração de solutos de baixo peso molecular e, o potencial mátrico é função da capacidade das moléculas de reter água, ou seja, as proteínas e os carboidratos insolúveis, que por serem hidrofilicos, são os responsáveis pela absorção de água pois, geralmente tem uma carga negativa que atrai o lado positivo da molécula de água; os lipídios, porém absorvem menos água (VERTUCCI \& LEOPOLD, 1987).

A pressão de turgescência, normalmente positiva, origina-se de uma força resultante da pressão exercida pela solução celular sobre a parede da célula em função da absorção e da retenção de água sob a influência do potencial osmótico, que gera, por parte da parede celular, uma pressão igual mas de direção oposta. Em sementes secas, praticamente apenas o potencial mátrico e o osmótico contribuem para o potencial hídrico total (BEWLEY \& BLACK, 1985).

No solo, o potencial mátrico é o mais importante na determinação do potencial hídrico total (BEWLEY \& BLACK, 1985). Segundo SHIOGA (1990), os solos na capacidade de campo desenvolvem potencial hídrico entre -0,01 e -0,05 MPa, enquanto que no ponto de murcha permanente, o potencial atinge valores próximos de -1,5 MPa. Tanto no solo como nas sementes, há colóides com forças de adsorção consideráveis, podendo gerar potenciais matriciais da ordem de -300 MPa. Entretanto, ordinariamente, os potenciais matriciais do solo não atingem valores tão extremos (SALISBURY \& ROSS, 1985).

Para LABOURIAU (1983), os potenciais hídricos desenvolvidos pelas sementes são suficientemente baixos para garantir, de forma generalizada, a hidratação inicial nas condições de disponibilidade hidrica existente naturalmente no solo.

As variações de quantidade de água promovem oscilações do potencial hídrico em uma escala negativa de valores (BEWLEY \& BLACK, 1985). Utiliza-se o 
potencial hídrico para medir a capacidade das moléculas de água executarem trabalho ou movimento, podendo ser expresso em unidade de energia (joule e erg) e essas unidades podem ser convertidas em unidades de pressão: $0,1 \mathrm{MPa}=1 \mathrm{Bar}=0,987 \mathrm{~atm}$ (SUTCLIFFE, 1980).

O gradiente hídrico pode ser manipulado pela alteração do potencial hídrico externo da semente e pela alteração do potencial hídrico das sementes. Alternando esses fatores, o mesmo ocorre com a velocidade de absorção de água pelas sementes (VERTUCCI, 1989).

$\mathrm{O}$ efeito da modificação do gradiente hídrico pela alteração do potencial hídrico externo da semente tem sido estudado usando substrato úmido (TILDEN \& WEST, 1985), soluções com várias quantidades de produtos químicos (POWELL \& MATTHEWS, 1978; WOODSTOCK \& TAO, 1981) e sistema de vapor expondo as sementes às diferentes condições de umidade relativa do ar (COLLIS-GEORGE \& MELVILLE, 1978). Em todos os casos, a embebição pode ser realizada de maneira gradual e, para isso, basta controlar a quantidade de água disponível à semente (VERTUCCI, 1989).

Quando a embebição for realizada em substrato úmido, a água permanece retida no substrato pelo potencial mátrico e não há possibilidade de confundir os efeitos dos tratamentos com os efeitos devido a absorção de produtos químicos. Assim, à medida em que se reduz o potencial, tornando o potencial mátrico mais negativo, a velocidade de absorção de água também diminui, sugerindo que abaixando o potencial hídrico ocorre uma redução da velocidade. Normalmente, tem-se empregado como substratos, papel toalha, vermiculita e terra. Quando o papel toalha é usado, fixam-se tanto o volume de água como a quantidade de sementes e varia-se o número de folhas de papel (PERL \& FEDER, 1981; TILDEN \& WEST, 1985; VERTUCCI, 1989). PANDEY (1988 e 1989) utilizaram de 1 a 5 folhas de papel com diâmetro de $150 \mathrm{~mm}$ umedecidas com $20 \mathrm{ml}$ de água. Já, HEYDECKER et al. (1973); FU et al. (1988) e ARMSTRONG \& MCDONALD (1992) utilizaram folhas de papel toalha umedecidas com soluções de polietilenoglicol. 
Por outro lado, em relação ao efeito do uso de soluções osmóticas na germinação, verifica-se que quando a velocidade de absorção de água é alterada pela adição de produtos químicos, a germinação de sementes pode ser drasticamente afetada, assim como, também, ocorre diminuição da germinação quando as sementes são colocadas para embeber em um meio com pequeno potencial hídrico. No entanto, raramente esta sensibilidade das sementes pode ser explicada apenas em função da alteração na velocidade de absorção de água pois, mesmo quando a velocidade torna-se lenta, a germinação e o vigor diminuem, porque a disponibilidade de água está tão reduzida que não promove a emergência da raiz primária e, apenas acelera a deterioração das sementes. Desta forma, reduzindo-se o potencial hídrico externo com o uso de produtos químicos, aumenta-se a viscosidade da solução e diminui-se a velocidade de absorção de água (VERTUCCI, 1989).

O potencial osmótico pode ser controlado através de produtos químicos, tais como o polietilienoglicol (PEG), manitol e sais inorgânicos $\left(\mathrm{NaCl}, \mathrm{MgSO}_{4}\right.$ e $\left.\mathrm{KNO}_{3}\right)$. O polietilenoglicol tem sido amplamente empregado, pois é um polímero de alto peso molecular, não iônico, inerte (STEUTER et al., 1981), que não penetra pelas paredes celulares (KNYPL \& KHAN, 1981) e não apresenta sinais de toxicidade (PARMAR \& MOORE, 1968; HEYDECKER \& COOLBEAR, 1977; BEWLEY \& BLACK, 1985). O polietilenoglicol de peso molecular 6000 (PEG 6000) tem sido o mais utilizado em função da densidade e da viscosidade (HEYDECKER et al., 1973 e 1975; EIRA, 1988; FU et al., 1988; SILVA, 1989; SHIOGA, 1990).

A simulação de deficiência hídrica, imposta pela utilização de soluções osmóticas com elevadas concentrações, produz efeitos menos drásticos sobre as plantas quando comparada com uma situação correspondente à mesma tensão da água no solo. Entretanto, em potenciais maiores ou pouco negativos, os valores obtidos para germinação apresentam a mesma tendência (SÁ, 1987).

Dentro deste contexto, o gradiente hídrico, além de ser alterado pelo potencial hídrico do meio, pode ser modificado pela alteração do potencial hídrico das sementes através da mudança no teor inicial de água, o que basicamente acontece com o processo de absorção de água, onde o gradiente diminui à medida em que as sementes 
vão se hidratando. Sementes com baixo teor de água embebem mais rapidamente que as com alto teor de água, pois o gradiente hídrico é enorme para as sementes secas e diminui exponencialmente quando as sementes são umedecidas. Assim, reduzindo-se o teor de água, diminuiu-se se o potencial hídrico da semente e ocorrem mudanças na permeabilidade da semente (VERTUCCI \& LEOPOLD, 1983; HSU, 1983).

\subsection{Reparo das membranas celulares}

O sistema de membranas celulares inclui o plasmalema, que delimita o conteúdo celular, o tonoplasto, que delimita os vacúolos e, as membranas do aparato de Golgi, do retículo endoplasmático, dos peroxissomas, dos glioxomas, dos esferossomas, dos plastídeos, das mitocôndrias e do núcleo (ABDUL-BAKI \& BAKER, 1973).

A estrutura das membranas celulares é descrita por SINGER \& NICOLSON (1972) como um modelo denominado mosaico fluído, onde tanto fosfolipídios como proteínas contribuem para regular a difusão de solutos celulares. Os fosfolipídios estão dispostos em camada dupla, com as extremidades hidrofóbicas, representadas pelos ácidos graxos de cadeia longa, voltadas para o interior, enquanto as hifrofilicas, representadas pelos grupos polares, se posicionam no sentido ao exterior aquoso. As proteínas se associam interna e extemamente à dupla camada lipídica, sendo denominadas, respectivamente, intrinsecas e extrínsecas. Conforme relatou CARVALHO (1994), as proteínas intrínsecas permitem o transporte de solutos através da camada lipidica, sendo abundantes quando o fluxo de substâncias é intenso. Enquanto isso, as proteínas extrínsecas, nas quais predominam sequências de aminoácidos hidrofilicos, mostram-se incapazes de atravessar o interior da membrana, tendo como a principal função a de capturar íons próximos à membrana celular que, posteriormente, seriam transportados para o interior da célula. De acordo com esse modelo, denominado mosaico fluido, a estrutura da membrana apresenta permeabilidade seletiva.

A permeabilidade das membranas é uma expressão da liberdade com que a água e os solutos podem passar através delas. Além disso, depende não somente da substância que está entrando, mas também da membrana em si, pois não são todas iguais 
em todos os organismos. Há circunstâncias nas quais a permeabilidade a um soluto varia de uma fase para outra na vida de uma célula; assim, tanto a senescência como a imposição a um estresse, como a desidratação, aumentam a permeabilidade (SIMON, 1974). Segundo LUZZATTI \& HUDSON (1962), sementes com teores de água inferiores a $167 \mathrm{~g} / \mathrm{kg}$ de sementes úmidas, são considerados insuficientes para manter a configuração típica da camada dupla das membranas em forma linear e, consequentemente, os fosfolipidios dispõem-se em forma hexagonal.

Para ABDUL-BAKI (1980), a organização das membranas é máxima na maturidade fisiológica; a partir desse momento, as organelas perdem sua organização estrutural a níveis variáveis, de tal forma que, à medida em que as sementes perdem água, seja naturalmente ou através do processo de secagem artificial, ocorre uma desorganização das membranas celulares.

Para BEWLEY \& BLACK (1985), é provável que, com a secagem, o tonoplasto e o plasmalema venham a perder a permeabilidade seletiva assim como a sua integridade e, dessa forma, possam perder a capacidade de reter os solutos dentro das células. Além disso, nessa situação, as membranas não mais atuariam como barreiras na fase inicial de absorção de água.

A desestruturação dos sistemas de membranas tem sido considerada como a primeira consequência da deterioração. embora provocando um aumento da permeabilidade, não se chegou a um consenso sobre quais seriam as causas básicas dessa desestruturação (CARVALHO, 1994). Para WILSON Jr. \& Mc DONALD Jr. (1986), as mudanças ocorreriam nos ácidos graxos insaturados pela ação de radicais livres, sendo esse processo conhecido como peroxidação. No entanto, também, em sementes com menor teor de água ocorre esse processo, sendo caracterizado como auto-catalítico (VILLIERS \& EDGCUMBE, 1975).

Desta forma. em relação a deterioração das sementes, tem-se que, a partir da degeneração das membranas, ocorrem manifestações fisiológicas que podem levar a semente até à morte, além de ocasionar germinação e crescimento inicial mais lentos, redução do potencial de armazenamento e da taxa de crescimento, menor uniformidade. maior sensibilidade a adversidades, redução da emergência das plântulas, formação de 
plantas estéreis e aberrações morfológicas (DELOUCHE, 1969). Assim, a continuidade do processo de deterioração, resulta primeiro em perda do vigor e por último, na perda da viabilidade (DELOUCHE \& BASKIN, 1973).

O grau de umidade da semente e a temperatura de armazenamento são os dois fatores de maior influência sobre a manutenção da viabilidade das sementes (WARD \& POWELL, 1983). O teor de água das sementes durante o armazenamento ou anterior à absorção de água influencia a subsequente germinação, de tal forma que, sementes com baixo teor de água, embora mais protegidas para o armazenamento, são particularmente suscetíveis a estresses durante a absorção de água (POLLOCK, 1969).

HEGARTY (1977) discutiu o efeito do teor de água em sementes ortodoxas durante o armazenamento e relatou que as sementes com teores muitos baixos de água estão sujeitas à peroxidação dos lipídios, ficando a viabilidade prejudicada. Com o aumento do nível de água, a deterioração é acelerada; porém, se suficientemente úmidas, as sementes germinam e, num nível intermediário, tem início o processo de ativação e reparo celular.

Durante a hidratação, pode ocorrer o reparo da membrana plasmática de maneira natural, com a reorganização dos fosfolipídios que a compõem (PANDEY, 1988) ou através da restauração por um mecanismo enzimático ainda não identificado perfeitamente (BEWLEY \& BLACK, 1985). Este reparo é um evento hipotético, aceito por alguns pesquisadores e questionado por outros (TILDEN \& WEST, 1985).

HEGARTY (1977) sugeriu que com a elevação do teor de água das sementes, deve haver um ponto de transição, em que os mecanismos de reparo celular predominam sobre os de deterioração das sementes. No entanto, em sementes mais deterioradas ou não viavéis, esses mecanismos de reparo estariam ausentes ou seriam ineficientes; ou ainda, as membranas estariam tão profundamente danificadas, que o reparo seria impossível (BEWLEY \& BLACK, 1985). ROBERTS (1981) admitiu que danos severos, desenvolvidos na fase anterior à morte das sementes, são irreversíveis e levam à redução do vigor e à produção de plântulas anormais, já que a maioria dos sistemas subcelulares estariam danificados. 
Segundo ELDER et al. (1987), o nível de dano e sua reversibilidade dependem da eficiência de certos mecanismos de reparo que estão relacionados ao metabolismo de ácidos nucléicos e com a possibilidade de recuperação das membranas deterioradas, de tal forma que parte da atividade metabólica, que ocorre durante o início da germinação, é dirigida para consertar ou substituir os componentes danificados.

O tempo necessário para que ocorra o reparo das membranas, ou seja, para que a integridade das membranas seja reparada, é pequeno após a embebição (SIMON \& RAJA HARUN, 1972). Para LEOPOLD (1980), a taxa de absorção de água e de liberação de solutos é maior nos primeiros minutos de embebição dos cotilédones de soja.

Segundo BEECROFT \& LOTT (1993), a quantidade de potássio exsudado aumentou com o tempo de absorção de água em ágar, sendo que após 20 minutos. $30 \%$ das sementes mostraram liberação e $88 \%$, após 60 minutos, concordando com LOTT et al. (1991).

WEBSTER \& LEOPOLD (1977) afirmaram que após 20 minutos de hidratação, a $25^{\circ} \mathrm{C}$, os cotilédones de sementes de soja anteriormente secos, já possuem as membranas reorganizadas restabelecendo a sua permeabilidade seletiva e evitando a exsudação excessiva pois, durante a absorção de água, ocorre o reparo da membrana plásmatica e outros eventos como a restruturação do retículo endoplasmático e o rápido desenvolvimento de numerosas cristas e denso estroma, o que se relaciona com o aumento da respiração.

Quando sementes severamente deterioradas são colocadas para absorver água, liberam maior quantidade de solutos que a mais vigorosas; nestas o restabelecimento da integridade das membranas celulares pode ser efetivado rapidamente, limitando a quantidade de substâncias no meio de hidratação (SIMON \& RAJAHARUM, 1972). LEOPOLD (1980) constatou que cotilédones mortos de soja liberam solutos muito mais rapidamente que os cotilédones vivos. Além disso, a liberação é maior após imersão das sementes em água (PARRISH \& LEOPOLD, 1977; POWELL \& MATTHEWS, 1981). 
Para o reparo, o prolongamento do período de absorção de água tem se mostrado eficiente, pois provocando-se a hidratação lenta, há possibilidade de restauração das membranas devido a uma reorganização metabólica a nível celular (KNYPL et al., 1980; KNYPL \& KHAN, 1981; WOODSTOCK \& TAO, 1981; WOODSTOCK \& TAYLORSON, 1981; PESKE, 1983; TILDEN \& WEST, 1985; FU et al., 1988; PANDEY, 1988 e ARMSTRONG \& McDONALD, 1992). Se for rápida, existe uma perda das substâncias antes que haja tempo para recomposição do mosaico fluido, quando a permeabilidade seria mais seletiva (SIMON \& MILLS, 1983).

TILDEN \& WEST (1985) verificaram que o maior benefício do uso de soluções osmóticas é a redução dos danos por embebição, através da diminuição da velocidade de absorção de água. Estes autores também constataram que o uso de soluções osmóticas reverte o efeito do envelhecimento e atribuiram esse efeito a possíveis reparos metabólicos resultantes da mudança dos componentes estruturais. Também, FU et al. (1988) observaram que o uso de soluções osmóticas sob baixas temperaturas teve um efeito positivo no reparo das membranas pois, com a reorganização da integridade da membrana, houve redução da velocidade de absorção de água e, consequentemente, menor liberação de solutos.

\subsection{Danos por embebição}

O mecanismo de danos por embebição, assim como, o por baixas temperaturas tem sido considerado como injúria física às membranas, ou seja, como um bloqueio ao sistema metabólico e, ainda, como uma combinação de injúria metabólica e fisica, possivelmente a nível molecular (POLLOCK, 1969).

Para que ocorra a germinação, as sementes precisam absorver água. Quando ocorre esse processo, as sementes podem, ao mesmo tempo, perder materiais soluvéis por difusão (LARSON, 1968). Para KUO (1989), a lixiviação de eletrólitos apresenta padrão idêntico ao da absorção de água pelas sementes de soja, sendo que lixiviação e absorção constituem reversos da mesma moeda. 
Assim, a redução no controle das relações de troca de água entre a semente e o substrato provoca sensíveis prejuizos para a primeira, relacionados ao metabolismo e ao controle da entrada de água, onde os resultados desse desequilíbrio são conhecidos como danos por embebição (VERTUCCI, 1989).

Durante a embebição, ADBUL-BAKI (1980) e SIMON \& RAJAHARUN (1972) relataram que o sistema de membranas das sementes se reorganiza, readquirindo sua permeabilidade; é ideal que este processo ocorra no menor período possivel, para reduzir a ocorrência de misturas indesejáveis do conteúdo celular e a lixiviação comprometedora de eletrólitos. Os danos por embebição podem constituir, portanto, em causa adicional à redução da emergência das plântulas, pois é a velocidade de reorganização do sistema de membranas que reflete o vigor das sementes.

Para VERTUCCI (1989), a eficiência de reorganização dos constituintes celulares, depende do teor inicial de água da semente, da temperatura ambiente e da velocidade de absorção de água; portanto, este fator não depende apenas do ambiente e inclui características intrínsecas da semente. Assim, é provável que os danos por embebição, também, estejam relacionados à qualidade fisiológica das sementes, pois a literatura tem indicado maior permeabilidade do tegumento nas mais deterioradas.

VERTUCCI \& LEOPOLD (1986) confirmaram que os danos por embebição são mais intensos em sementes de soja com teor de água inferior a $74 \mathrm{~g} / \mathrm{kg} \mathrm{de}$ sementes úmidas e são atenuados quando apresentam os teores de água de 100 a 130 $\mathrm{g} / \mathrm{kg}$. Além disso, HOBBS \& OBENDORF (1972) verificaram que os danos por embebição para soja foram maiores quando o teor de água esteve entre 48 a $56 \mathrm{~g} / \mathrm{kg}$ de sementes úmidas e, ASHWORTH \& OBENDORF (1980) observaram que o eixo embrionário pode ser protegido pelos danos por baixa temperatura mediante a elevação do teor de água para $145 \mathrm{~g} / \mathrm{kg}$ sementes úmidas. BRAMLAGE et al. (1978) mostraram que embriōes isolados de soja com teor abaixo de $187 \mathrm{~g}$ de água $/ \mathrm{kg}$ de sementes úmidas foram particularmente mais sensiveis a baixas temperaturas durante a embebição e que eixos embrionários com teor de água de $260 \mathrm{~g} / \mathrm{kg}$ de sementes úmidas parecem ser protegidos pelo efeito de injúria por baixa temperatura. 
Danos por embebição em sementes secas podem ser devidos à peroxidação de lipídios e alterações nas proteínas das membranas, sendo que esse processo é autoxidação e, em geral, danifica todas células. $\mathrm{O}$ fato dos tecidos estarem secos não previne necessariamente a reação de peroxidação, pois a pequena quantidade de água remanescente restringe a tenacidade das células coloidais e ainda permite a peroxidação, devido à proximidade da água e do oxigênio com a dupla ligação de lipídios insaturados da membrana citoplasmática. Assim, embora muitas enzimas controlem estas reações, especialmente as que envolvem estruturas unitárias, estas proteínas provavelmente não ocorrem nestas células que apresentam baixo teor de água (VILLIERS \& EDGCUMBE, 1975).

Portanto, a perda da viabilidade de sementes armazenadas é causada pela sua inabilidade em operar o sistema de reparo dos tecidos, devido ao baixo teor de água disponível. Assim, os danos se acumulam e somente poderão ser reparados quando as sementes forem embebidas para a germinação. Entretanto, em sementes enterradas no solo, a sequência de ganho e perda de água, que ocorre naturalmente, faz com que esse processo todo seja desencadeado e com isso a semente pode permanecer viável por um longo período (VILLIERS \& EDGCUMBE, 1975).

ELLIS et al. (1990) concluiram que sementes secas de alguns lotes de ervilha são suscetíveis aos danos por embebição no teste de germinação; a proporção de sementes suscetiveis a esses danos pode aumentar com a redução do teor de água de 148 para $37 \mathrm{~g} / \mathrm{kg}$ de sementes úmidas. Para esses autores, os danos a sementes com baixo teor de água parecem ser uma consequência dos danos por embebição e não devido à dessecação por si só; os danos poderiam ser evitados pelo umedecimento das sementes antes do teste. No entanto, esse umedecimento pode acelerar o processo de deterioração, ou seja, de envelhecimento, depedendo do tempo de umedecimento, do estado físico da água, da temperatura do ambiente e do teor inicial de água.

Resultados de germinação de sementes de soja e de emergência de plântulas também revelam a ocorrência de danos por umedecimento das sementes devido a um rápido período de absorção de água e ao teor de água das sementes (MUNDEL, 1986). 
Alguns cuidados são requeridos quando se decide pelo tratamento de umedecimento; de acordo com ELLIS et al. (1990), o teor de água deve estar entre 152 a $166 \mathrm{~g} / \mathrm{kg}$ de sementes úmidas e é recomendável fornecer água para as sementes no estado de vapor.

Além do teor de água das sementes, já citado, também a disponibilidade hídrica do substrato merece destaque por suas relações com o processo de germinação. Estes danos causados pela embebição são manifestados por uma diminuição no vigor das plântulas, ocorrendo germinação anormal (HOBBS \& OBENDORF, 1972). Em condições de excesso de água, a semente poderá absorver água muito rapidamente, ocasionando rupturas em seus tecidos (HOBBS \& OBENDORF, 1972).

Considerando o solo como substrato, a presença de água, em potencial hídrico próximo ou igual a zero, não é favorável para as espécies desprovidas de mecanismos especiais de transporte de oxigênio. Nestas condições, são detectáveis prejuízos provenientes das dificuldades de aeração, com consequente carência de oxigênio além dos danos embrionários provocados por embebição demasiadamente rápida (PESKE \& DELOUCHE, 1985). ELLIS et al. (1990) relataram que danos por embebição podem explicar a redução da germinação e de vigor de plântulas de ervilha sob condição de solo não aerado. Além disso, nesta situação também tem sido constatada uma elevação da incidência de microrganismos na semente de soja em germinação (SÁ, 1987).

Por outro lado, em condições de baixa disponibilidade de água do solo, a semente inicia a germinação e, não havendo água suficiente para a sua continuidade, ocorre a morte do embrião (HOBBS \& OBENDORF, 1972). Além disso, os relatos de PEREIRA et al. (1981) mostraram que à medida em que a semente de soja permanece no solo sem emergir, devido à deficiência de água, ocorre ataque de microrganismos estimulados pela exsudação de açúcares. Esta pois, seria uma situação em que o baixo potencial da água do solo tornaria mais lento o processo germinativo e, dessa forma, as sementes ficariam expostas ao ataque de microrganismos. Assim, a falta de água provoca danos diretos e indiretos à germinação. 
De acordo com HUNTER \& ERICKSON (1952), em estudos com diversos tipos de solos, as sementes de soja germinam após terem alcançado determinados teores mínimos de água, independentemente do solo estudado. Além disso, para esses autores, as sementes de soja germinam em diferentes solos que apresentam até uma tensão de -0,66 MPa, sendo que a germinação é mais satisfatória à medida em que diminui a tensão. No entanto, para HEATHERLY \& RUSSELL (1979), a velocidade de emergência da plântula de soja em relação aos potenciais hídricos varia com o tipo do solo, onde no de textura argilosa, ocorre melhor germinação, quando a tensão de água é de -0,1 a - $0,7 \mathrm{MPa}$ e, no solo de textura média, quando a água a ser retirada está retida por tensões de -0,4 e -0,6 MPa. Também, SÁ (1979) observou diminuição da velocidade e da porcentagem de emergência de plântulas a partir do potencial hídrico de $-0,20 \mathrm{MPa}$.

De forma geral, a redução do potencial hídrico provoca prejuízos tanto à raiz primária quanto à parte aérea (YOUNG et al., 1983). No entanto, para McGINNIES (1960), espécies que germinam adequadamente sob baixos potenciais hídricos não são, necessariamente, aquelas que sobreviverão sob severas condições de estresse hídrico.

Quando ocorre falta ou excesso de água, o tratamento fungicida pode ser benéfico para manter a viabilidade das sementes (SÁ, 1987). Para PESKE \& DELOUCHE (1985), os fungicidas proporcionam uma proteção limitada às sementes de soja, até um determinado período de tempo a partir do qual, a deterioração fisiológica aumenta acentuadamente, resultando em drástica perda da viabilidade.

Fixada a espécie, a resposta das sementes colocadas para germinar sob deficiência hídrica tem se mostrado dependente da qualidade fisiológica. Em termos gerais, menor qualidade fisiológica tem sido associada aos piores desempenhos (PARMAR \& MOORE, 1968; MATTHEWS \& POWELL, 1986). Para SÁ (1987), as sementes de soja mais vigorosas mostraram-se mais resistentes às condições de deficiência hídrica. Além disso, a baixa disponibilidade de água reduziu o comprimento do hipocótilo, da raiz primária das plântulas e o acúmulo de matéria seca nas plântulas de soja.

ROCHA et al. (1984), em estudos sobre a relação entre absorção de água e a qualidade das sementes de soja, observaram que sementes de pior qualidade absorvem 
maior volume de água e apresentam menor índice de resistência ao enrugamento. Resultados semelhantes foram obtidos por VIEIRA (1980) que, apoiado nos dados de ABDUL-BAKI \& ANDERSON (1972), atribui a diminuição do índice de resistência ao enrugamento das sementes de soja, ao fato de que a permeabilidade do tegumento também aumenta com a deterioração.

\subsection{Injúria por baixas temperaturas}

O mecanismo de injúrias por baixas temperaturas na embebição tem sido discutido em relação à ruptura de membrana, à velocidade de hidratação e ao teor de água. Para milho, ocorrem lesões nas raiz primária após injúria por baixa temperatura e para soja, aparecem as fendas nos cotilédones (OBENDORF \& HOBBS, 1970; HOBBS \& OBENDORF, 1970). No entanto, aparecem lesões no eixo embrionário devido a rápida hidratação, independentemente da temperatura, quando o tegumento das sementes com baixo teor de água for removido ou quebrado (ASHWORTH \& OBENDORF, 1980).

A grande sensibilidade das sementes em relação às baixas temperaturas tem sido comparada aos danos por embebição pois, em ambas as situações, ocorre redução na germinação e no desenvolvimento das plântulas. Além disso, a injúria por baixas temperaturas é controlada através da elevação do teor de água das sementes. No entanto, na literatura, os danos atribuidos à baixa temperatura podem ter sido resultado dos danos por embebição, pois a água tem rápido acesso ao embrião quando o tegumento é removido e, além disso, o exame das condições do tegumento para a qualidade de sementes não foi realizado (POWELL \& MATTHEWS, 1978).

Durante a embebição, a entrada de água no estado líquido causa injúrias aos tecidos e baixas temperaturas podem ampliar este estresse. No entanto, a absorção de água no estado de vapor não é tão prejudicial como baixas temperaturas (BEDI \& BASRA, 1993). Assim, define-se a injúria por baixas temperaturas como a sensibilidade à combinação entre o teor de água das sementes e a temperatura do ambiente por ocasião da hidratação, concordando com as informações de POLLOCK (1969) que. trabalhando 
com sementes de feijão, relatou que baixas temperaturas podem interagir com baixo teor de água e resultar em maiores injúrias.

Usualmente, sementes com 50 a $110 \mathrm{~g}$ de água $/ \mathrm{kg}$ de sementes úmidas são mais injuriadas e sementes com 130 a $140 \mathrm{~g}$ de água $/ \mathrm{kg}$ são mais protegidas; temperaturas críticas são aquelas menores que $10^{\circ} \mathrm{C}$, em sementes de grandes culturas, e menores que $15^{\circ} \mathrm{C}$ em olerícolas (BEDI \& BASRA, 1993).

Consequentemente, sob condições de baixas temperaturas, ocorre um aumento do período em que as sementes perdem lixiviados quando imersas em água, sendo interpretado por BRAMLAGE et al. (1981) como sendo devido à demora ou falha na reorganização dos fosfolípidios das membranas. Desta forma, para estes autores, a maior resistência dos embriões de soja às baixas temperaturas, quando apresentam maiores teores de água, seria devida, ao menos em parte, à configuração da camada dupla em forma linear das membranas.

OBENDORF \& HOBBS (1970) e HOBBS \& OBENDORF (1972) consideraram que o baixo teor de água das sementes em solo úmido é responsável pela ocorrência de fendas transversais nos cotilédones devido ao estresse físico imposto pela hidratação diferenciada dos tecidos internos. No entanto, a redução da sobrevivência e do vigor das plântulas não estiveram relacionados com a quebra dos cotilédones resultante da rápida hidratação de semente com baixo teor de água (OBENDORF \& HOBBS, 1970; HOBBS \& OBENDORF, 1972), com a liberação de açúcares, com a atividade microbiana, nem com a injúria por embebição e anaerobiose (HOBBS \& OBENDORF, 1972).

Dentro deste contexto, os danos por baixas temperaturas são controlados pelo aumento do teor de água através da absorção de água, principalmente, no estado de vapor (OBENDORF \& HOBBS, 1970; HOBBS \& OBENDORF, 1972; VERTUCCI \& LEOPOLD, 1983), bem como por tratamentos com soluções osmóticas os quais retardam a velocidade de absorção de água (WOODSTOCK \& TAO, 1981). 


\subsection{Manifestações das alterações das membranas}

Para ABDUL-BAKI (1980), os danos por embebição são manifestados pelo aumento na saída de solutos das sementes, redução no vigor ou incapacidade das sementes de produzir plântulas normais.

Paralelamente à entrada de água, as sementes liberam, dentro da própria célula e para fora da célula, açúcares, ácidos orgânicos, aminoácidos, enzimas e vários íns, tais como sódio, potássio, cálcio, em quantidades inversamente proporcionais a organização dos sistemas de membranas e a atividade dos mecanismos de reparo, ou seja, as mais deterioradas e as com tegumentos trincados ou escarificados, normalmente liberam maiores quantidades de exsudatos, sendo que em condições de campo, esses solutos, principalmente os açúcares, podem estimular o desenvolvimento de microrganismos, prejudicando o estabelecimento das plântulas. No entanto, nas sementes mais vigorosas, o restabelecimento da integridade do sistema de mebranas celulares ocorre mais rapidamente, minimizando esse problema de microrganismos (MARCOS FILHO, 1986).

LOTT et al. (1991) quantificaram o total de ions potássio, magnésio, cloro, cálcio e manganès exsudatos durante a embebição de sementes de diversas espécies, dentre as quais, soja e ervilha ou de partes isoladas destas e, relataram que o potássio foi, de modo geral, o elemento liberado em maior quantidade, enquanto que o manganês, foi o menos liberado. Para BEECROFT \& LOTT (1993), a soja libera potássio através de toda a superficie do tegumento, de tal forma que a água entra na semente através do tegumento e não apenas no hilo (SWANSON et al., 1985).

A lixiviação de solutos durante a fase de embebição pode ser explicada por várias hipóteses, sendo que uma delas propõe que os solutos lixiviados durante a embebição estariam localizados no apoplasto (SIMON, 1974), fato este divergente do obtido por SIMON \& RAJA-HARUN (1972) que verificaram que embriões de ervilha previamente umedecidos, ou que não tinham sido submetidos à secagem durante o processo de maturação, não perdiam eletrólitos quando imersos em água. Também, SIMON \& MILLS (1983) mostraram que a quantidade elevada de eletrólitos perdidos 
em 24 horas, é bem superior a que parece existir extra célula; além disso, a grande diversidade dos solutos perdidos sugere a origem citoplasmática, o que inviabiliza a hipótese anterior de SIMON (1974).

LARSON (1968) apresentou outra hipótese, a da ruptura das membranas. Assim, devido ao elevado gradiente hídrico no início da embebição, as membranas das células poderiam se romper, o que dispersaria seus componentes. Porém, SIMON (1984) demonstrou que a lixiviação ocorre ainda que a embebição seja lenta em embriões de ervilha, e que a lixiviação de potássio continua por horas após as células periféricas terem sido umedecidas.

Para POWELL \& MATTHEWS (1978), a morte dos tecidos na superficie abaxial dos cotilédones, detectada em teste de tetrazólio, quando ocorreu a rápida absorção de água pelos embriões de ervilha, dá suporte a hipótese de LARSON (1968), segundo a qual o alto nível de liberação de íons e de redução do desenvolvimento de plântulas observada em sementes embebidas de ervilha, foi devido aos danos ocorridos durante a embebição, como um resultado da ruptura das membranas das células causada pela rápida entrada de água. Além disso, quando ocorreu a rápida absorção de água pelos embriões de ervilha, constatou-se uma grande liberação de solutos, a qual pode ser explicada pela ruptura das membranas internas, como proposta por SIMON \& RAJAHARUN (1972). Além disso, estes autores relataram que o fator importante na minimização dos danos por embebição é a capacidade do tegumento de evitar a rápida embebição.

Dentro deste contexto, SIMON \& MILLS (1983) e SIMON (1984) propuseram uma outra hipótese. Para estes autores, as sementes quando secas apresentam membranas desorganizadas, ou seja, sem barreiras em volta do citoplasma de cada célula, o que facilita a lixiviação de solutos; com a embebição sua condição de semipermeabilidade é restabelecida, concordando com LUZZATI \& HUDSON (1962), que verificaram que sementes com teor de água abaixo de $167 \mathrm{~g} / \mathrm{kg}$ de sementes úmidas, apresentam membrana porosa não mais à prova de água, podendo ser permeáveis a solutos. No entanto, após a hidratação, as membranas retornam à forma laminar evitando a perda de eletrólitos. 
Dados obtidos por DUKE et al. (1983) sugeriram que a liberação de eletrólitos pelas sementes de soja em embebição é devida, principalmente, à difusão passiva, enquanto a difusão de macromoléculas intra celulares é dependente, fundamentalmente, de um fenômeno fisiológico que afeta a integridade das membranas.

Diferenças na liberação ocorrem entre cultivares de mesma espécie (ROWLAND \& GUSTA, 1977; POWELL et al., 1986). Segundo BEECROFT \& LOTT (1993), alguns cultivares de soja apresentam pequenos poros e alta densidade de materiais no tegumento, como foi constatado por CALERO et al. (1981) e YAKLICH (1985), fazendo com que ocorra uma menor velocidade de entrada de água e, consequentemente menor liberação, concordando com POWELL et al. (1986).

$\mathrm{O}$ conceito de que a água entrando nos tecidos permite a reorganização das membranas e que baixas temperaturas interferem nesta reorganização foi sugerido primeiramente por HERRERA et al. (1956). Além disso, LEOPOLD (1980) defendeu o conceito de que baixas temperaturas interferem na reorganização natural das membranas durante a entrada de água nas sementes de soja.

Por outro lado, a perda de solutos durante a embebição varia diretamente com o teor de água dos tecidos, sendo que as mais secas sementes de soja liberam maior quantidade de íons quando embebidas rapidamente (TAO, 1978; BECWAR et al., 1982; ISHIDA et al., 1988; LOEFFLER et al., 1988).

Para PARRISH \& LEOPOLD (1977), a liberação de íons, avaliada pela condutividade elétrica da solução, varia com o teor inicial de água das sementes de soja, sendo que as mais secas, com $35 \mathrm{~g}$ de água/kg de sementes úmidas, mostraram maior liberação que as mais úmidas (com 78 a $88 \mathrm{~g}$ de água $/ \mathrm{kg}$ ). Essa interpretação é confundida pela fratura dos cotilédones das sementes secas devido ao aumento da área superficial que, consequentemente, facilita a perda de material intra e intercelular.

De acordo com TAO (1978), sementes de soja com teores iniciais de água de 131 a $195 \mathrm{~g} / \mathrm{kg}$ de sementes úmidas, apresentam valores semelhantes de condutividade elétrica; entretanto, há aumento significativo nas leituras quando o teor de água das sementes for inferior a $88 \mathrm{~g} / \mathrm{kg}$, de tal forma que levou o autor a sugerir que a condução deste teste deve ser realizada com sementes com teor de água superior a $130 \mathrm{~g} / \mathrm{kg}$. 
Resultados semelhantes foram obtidos por LOEFFLER et al. (1988), também com soja, indicando que o teor de água inferior a $110 \mathrm{~g} / \mathrm{kg}$ contribui para o aumento da condutividade elétrica, enquanto são pequenas as diferenças que ocorrem quando os teores de água permanecem entre 110 a $180 \mathrm{~g} / \mathrm{kg}$.

Dentro deste contexto, POWELL (1986) relatou que a quantidade e intensidade de material lixiviado estão diretamente relacionadas à permeabilidade do tegumento e, consequentemente, são influenciadas pela idade da semente, pela sua condição fisiológica e também pela incidência de danificações.

Segundo BEECROFT \& LOTT (1993), sementes de soja envelhecidas e com danos nos tegumentos liberaram mais solutos que sementes novas e sem danos nos tegumentos, concordando com LOOMIS \& SMITH (1980); SCHOETTLE \& LEOPOLD (1984) e BRUGGINK et al. (1991), que a liberação aumenta com a idade e com a presença de danos nos tegumentos. Assim, se a água entra através do tegumento, então pequenas moléculas, como as do potássio, podem ser capazes de se difundir por ele. Além disso, LOTT et al. (1991), observaram que as partes do tegumento da soja que estavam mortas liberaram mais ions que partes vivas.

Com base nestas considerações, a quantidade de ions liberados pelas sementes tem sido avaliada através da condutividade elétrica da solução de embebição, sendo que alguns trabalhos têm relacionado a germinação às quantidades de íns liberados durante a embebição (POWELL, 1986). Este fenômeno sugere que, em sementes de soja, a perda da integridade das membranas das células do embrião, com consequente liberação de constituintes celulares (PARRISK \& LEOPOLD, 1978)

LIN (1990) observou que sementes de feijão anão francês, envelhecidas sob $45^{\circ} \mathrm{C}$, apresentaram menor germinação e vigor e lixiviaram mais eletrólitos quando colocadas na água destilada por 17 horas. Tal observação sugeriu uma relação intima entre deterioração das sementes e perda de vigor e germinação, concordando com a hipótese de que a deterioração das sementes, durante o período de absorção de água envolve mudanças nas membranas, o que predispõe os tecidos embrionários a danos por embebição. 
WOODSTOCK \& TAO (1981) mostraram que o envelhecimento artificial de sementes de soja sob temperatura de $41^{\circ} \mathrm{C}$ a $100 \%$ de umidade relativa do ar, predispôs o eixo embrionário a danos durante o ínicio da embebição, de tal forma que, neste período, a lixiviação eletrolítica de eixos embrionários de sementes com baixo vigor foi 6 vezes maior que de eixos embrionários com alto vigor e, ainda, a taxa de perda de eletrólitos foi mais pronunciada nas etapas iniciais de embebição, sendo que a partir de 20 horas de embebição, não foi constatada exudação.

Além disso, OLIVEIRA (1990) constatou que alguns cultivares de soja apresentaram correlação significativa entre a perda de germinação e a exsudação de íons por sementes embebidas. $\mathrm{O}$ autor quantificou a presença de íons cálcio, magnésio, sódio e potássio medidos no exsudato de sementes após 90 minutos de imersão em água deionizada, sob temperatura de $28^{\circ} \mathrm{C}$. A extensão desta liberação de íons foi relacionada com a emergência de plântulas (BRADNOCK \& MATTHEWS, 1970).

Os trabalhos apresentados nesta revisão bibliográfica evidenciaram a relevância dos vários aspectos do processo de absorção de água para a germinação de sementes de soja. Esta é afetada pelas características das sementes e pelas condições do ambiente, com destaque para a disponibilidade de água.

O gradiente hídrico entre a semente e o substrato dirige a absorção de água; a velocidade de absorção depende da permeabilidade do tegumento, do teor de água e da qualidade fisiológica das sementes, da disponibidade hídrica e da temperatura do ambiente. Desta forma, a entrada rápida de água, tal como em sementes com menor teor de água, pode provocar danos por embebição, frequentemente, manifestados pela liberação de solutos e queda de vigor.

Assim, pode-se constatar a importância do assunto e a necessidade da pesquisa visando elucidar os efeitos da qualidade fisiológica das sementes conjuntamente com a influência de outros fatores, como o teor inicial de água das sementes e o potencial hídrico do substrato. 


\section{MATERIAL E MÉTODOS}

A fase experimental foi conduzida nas instalações do Laboratório de Sementes do Departamento de Agricultura da Escola Superior de Agricultura "Luiz de Queiroz", da Universidade de São Paulo (LAG/ESALQ/USP), em Piracicaba, Estado de São Paulo.

Foram utilizados $15 \mathrm{~kg}$ de sementes de soja (Glycine max (L.) Merrill) do cultivar IAC-15, com teor de água de $90 \mathrm{~g} / \mathrm{kg}$ de sementes úmidas, fornecidos pelo Instituto Agronômico do Estado de São Paulo (IAC) e armazenados em condições médias controladas de $20^{\circ} \mathrm{C}$ e $50 \%$ de umidade relativa do ar.

Para controlar os possíveis efeitos do tamanho das sementes, cuja variabilidade pode interferir no seu desempenho, as sementes foram classificadas por espessura, pela passagem em uma série de peneiras de crivos oblongos, superpostas em ordem decrescente $(15 / 64 \times 3 / 4$ a $10 / 64 \times 3 / 4$ de polegada), para aproveitamento daquelas retidas na peneira $13 \times 3 / 4$ (tamanho médio). Em seguida, estas sementes foram homogeneizadas em divisor cônico tipo Boerner e divididas em três amostras de $5 \mathrm{~kg}$ que passaram a constituir os lotes 1,2 e 3 .

\subsection{Obtenção da variabilidade entre lotes}

Para estudar o efeito da qualidade fisiológica no processo de absorção de água, foram usadas sementes de mesmo histórico de produção; porém, os diferentes níveis de qualidade fisiológica foram obtidos pela aplicação do envelhecimento artificial nos lotes 2 e 3, com base em informações obtidas em testes preliminares. 
Desta forma, os lotes 2 e 3 foram divididos em quatro repetições que, em duplas, foram submetidas ao envelhecimento acondicionadas em sacaria de filó. Foi empregada câmara de envelhecimento DeLeo, modelo 5001 , a $41^{\circ} \mathrm{C}$ durante 36 horas (Lote 2) e 42 horas (Lote 3).

No final dos procedimentos para o envelhecimento artificial, foi realizada a determinação do teor de água pelo método da estufa (BRASIL, 1992) e as sementes foram colocadas em secador Marconi, modelo 35 , sob temperatura de $30^{\circ} \mathrm{C}$ até atingirem o teor de água inicial ( $90 \mathrm{~g}$ de água $/ \mathrm{kg}$ de sementes úmidas).

As sementes dos três lotes foram tratadas com Thiabendazol (Tecto 100), na proporção de $20 \mathrm{~g}$ do ingrediente ativo/100 $\mathrm{kg}$ de sementes $(150 \mathrm{~g} / 100 \mathrm{~kg})$, de acordo com HENNING et al. (1992).

\subsection{Caracterização dos lotes}

Para caracterizar os 3 lotes, foram realizados os testes de viabilidade (germinação e tetrazólio), de vigor (primeira contagem do teste de germinação, condutividade elétrica, envelhecimento acelerado e tetrazólio), além da determinação do peso de 1000 sementes e do grau de umidade.

\subsubsection{Teste de germinação}

$O$ teste de germinação foi conduzido com quatro repetições de 50 sementes por lote. Estas sementes foram distribuídas em substrato de papel toalha Germitest, umedecido com água destilada, na razão de 2,5 vezes o peso do papel no momento da instalação; o conjunto, após confecção dos rolos, foi levado para germinador Stults, regulado à temperatura constante de $25^{\circ} \mathrm{C}$.

Foram efetuadas avaliações no quinto e oitavo dias após a semeadura. Os resultados foram expressos em porcentagem média para cada lote, através da somatória de plântulas normais nas duas contagens, de acordo com descrição encontrada nas Regras para Análise de Sementes (BRASIL, 1992). 


\subsubsection{Primeira contagem de germinação}

Este teste foi realizado em conjunto com o de germinação, considerandose a porcentagem de plântulas que, no quinto dia após a instalação do teste, apresentavam as características de normalidade descritas nas Regras para Análise de Sementes (BRASIL, 1992) e o comprimento mínimo de $3 \mathrm{~cm}$. Os resultados foram expressos em porcentagem média para cada lote.

\subsubsection{Condutividade elétrica}

A determinação da condutividade elétrica foi realizada de acordo com LOEFFLER et al. (1988), utilizando quatro repetições de 50 sementes por lote.

Após a pesagem em balança com sensibilidade de $0,001 \mathrm{~g}$, as sementes puras foram submersas em $75 \mathrm{ml}$ de água destilada, no interior de copos plásticos e, a seguir, mantidas por 24 horas em câmara regulada à temperatura de $25^{\circ} \mathrm{C}$.

Ao final deste período, foi determinada a condutividade elétrica da solução em um condutivímetro Digimed, modelo CD-20 e sensor Sensotec, modelo 704. Os resultados foram expressos em $\mu$ mhos $/ \mathrm{cm} / \mathrm{g}$ de sementes para cada lote.

\subsubsection{Envelhecimento acelerado}

O teste de envelhecimento acelerado foi conduzido com cerca de 300 sementes $(42 \mathrm{~g})$ por lote, distribuídas sobre tela de alumínio fixada no interior de uma caixa plástica tipo "gerbox". Estas caixas, tampadas e contendo $40 \mathrm{ml}$ de água ao fundo, foram mantidas em incubadora FANEM, modelo $347 \mathrm{~F}$, regulada à temperatura de 41 ${ }^{\circ} \mathrm{C}$, durante 48 horas.

Após este período, as sementes foram colocadas para germinar conforme descrição anteriormente apresentada para o teste de germinação. A avaliação das plântulas foi realizada, quatro dias após a instalação, computando-se a porcentagem de 
plântulas normais (FRATIN \& MARCOS FLHO, 1984). Os resultados foram expressos em porcentagem média para cada lote.

\subsubsection{Teste de tetrazólio}

O teste de tetrazólio foi conduzido de acordo com as recomendações de FRANÇA NETO et al. (1988). Para cada lote, foram utilizadas duas repetições de 50 sementes, pré-condicionadas em papel toalha umedecido com água destilada na razão de 2,5 vezes o peso do papel, no momento da instalação. O conjunto foi mantido em germinador Stults, regulado à temperatura de $25^{\circ} \mathrm{C}$, durante 16 horas.

Decorrido este período, as sementes foram submersas em $20 \mathrm{ml}$ de solução de cloreto $2,3,5$ trifenil tetrazólio (concentração de $0,075 \%$ ) no interior de copos plásticos e, levadas para estufa termoelétrica, à temperatura de $40^{\circ} \mathrm{C}$, durante 2,5 horas. Em seguida, as sementes foram lavadas em água corrente e mantidas submersas em água até o momento das avaliações.

Finalizado o processo de coloração no tetrazólio, as sementes foram analisadas individualmente, após seccionamento longitudinal entre os cotilédones. As duas metades foram separadas e o tegumento removido para exposição da superfície externa dos cotilédones, observando-se a ocorrència de injúrias mecânicas, de danos causados por percevejos e de deterioração por "umidade".

Para a informação dos resultados, cada semente foi classificada em níveis de viabilidade, ou seja, categorias de I a 8. Após essa avaliação, registraram-se os níveis de vigor, viabilidade e a identificação da causa que possa ter levado a classificar a semente em cada referido nível de viabilidade.

Para cada lote, a somatória dos percentuais das classes 1 a 3 forneceu um índice de vigor (TZ 1-3) e a somatória dos valores de 1 a 5 indicou a viabilidade de cada lote de sementes (TZ 1-5). A diagnose da deterioração por "umidade" foi efetuada através do exame das sementes viáveis incluídas nas classes 1 a 5 (TZ 1-5) e das não viáveis, incluídas nas classes 6 a 8 (TZ $6-8)$, identificando-se os danos e calculando as suas porcentagens. 


\subsubsection{Grau de umidade}

O grau de umidade das sementes foi avaliado pelo método da estufa, a $105^{\circ} \mathrm{C}$, durante 24 horas, utilizando-se duas repetições, conforme as Regras para Análise de Sementes (BRASIL, 1992). Os resultados foram expressos em gramas de água/kg de sementes úmidas, para cada lote.

\subsubsection{Peso de mil sementes}

O peso de mil sementes foi conduzido e calculado de acordo com as Regras para Análise de Sementes (BRASIL, 1992). Os resultados foram expressos em gramas para cada lote.

\subsection{Obtenção de sementes com diferentes teores de água}

Os três lotes permaneceram armazenados em condições de ambiente controlado, com temperatura média de $20^{\circ} \mathrm{C}$ e umidade relativa do ar de $50 \%$, durante o periodo experimental.

Para cada lote, visando a obtenção de sementes com 110 e $130 \mathrm{~g}$ de água $/ \mathrm{kg}$, além das sementes que apresentavam-se com o teor inicial de água de $90 \mathrm{~g} / \mathrm{kg}$, foram adotados determinados procedimentos para o umedecimento artificial.

Para o umedecimento artificial das sementes, foram empregadas caixas plásticas tipo "gerbox" de acordo com ROSSETTO \& MARCOS FILHO (1995). Assim, amostras de $42 \mathrm{~g}$ (cerca de 300 sementes) foram distribuidas sobre a tela interna de cada caixa. Estas caixas, tampadas e contendo $40 \mathrm{ml}$ de água no fundo, foram mantidas em incubadora FANEM, modelo $347 \mathrm{~F}$, sob temperatura de $20^{\circ} \mathrm{C}$. Durante a permanência das caixas na incubadora foi realizado, periodicamente, o monitoramento da quantidade de água absorvida pelas sementes através da pesagem dessas sementes, conhecendo-se, 
de antemão, através de cálculos, quais pesos deveriam ser atingidos para que se pudesse obter os teores de água desejados.

No final do processo, para verificação final do grau de umidade alcançado, foi realizada a determinação dos teores de água das sementes umedecidas, através do método da estufa a $105^{\circ} \mathrm{C}$, durante 24 horas, de acordo com as Regras para Análise de Sementes (BRASL, 1992). Os resultados foram expressos em gramas de água/kg de sementes úmidas, para cada teor de água e cada lote.

Estas sementes, após o umedecimento artificial, foram colocadas no interior de recipentes de vidro $(250 \mathrm{ml})$ fechados e permaneceram em câmara fria (temperatura de $10^{\circ} \mathrm{C}$ e umidade relativa do ar de $96 \%$ ) por um período de 5 dias para uniformização do teor de água das sementes.

\subsection{Caracterização das sementes após umedecimento artificial}

Amostras de sementes de cada lote, com 90, 110 e $130 \mathrm{~g}$ de água $/ \mathrm{kg}$, sendo esses dois últimos teores obtidos após umedecimento artificial, foram avaliadas quanto ao peso de 1000 sementes, à viabilidade (através dos testes de germinação e de tetrazólio) e ao vigor (através dos testes de primeira contagem de germinação, condutividade elétrica, envelhecimento acelerado e tetrazólio). Os procedimentos de cada teste seguiram as mesmas descrições apresentadas em 3.2, utilizando-se quatro repetições para cada teor de água e cada lote.

Estes resultados foram utilizados como base para comparação com o comportamento das sementes nas etapas seguintes, inclusive com as porcentagens de sementes embebidas durante diferentes períodos de embebição.

\subsection{Avaliação da absorção de água}

Para cada lote, foi realizado o estudo das marchas de absorção de água e a avaliação da emissão de raiz primária, das sementes intumescidas e da ocorrência de danos por embebição. 
Para tanto, amostras de sementes, com 90, 110 e $130 \mathrm{~g}$ de água $/ \mathrm{kg}$, foram colocadas para absorver água em papel Germitest sob plena disponibilidade hídrica (potencial hidrico de -0,04 MPa), com base em SHIOGA (1990) e sob deficiência hídrica (potenciais hídricos de $-0,10 ;-0,20$ e -0,40 MPa), com base em SÁ (1987), através do umedecimento do papel com soluções aquosas de polietilenoglicol Synth (PEG 6000), considerando as amplas possibilidades desse produto para alcançar as situações de deficiência hídrica requerida, a inércia química e a facilidade prevista no seu manuseio (HEYDECKER et al., 1975).

As quantidades do soluto, obtidas com base na equação sugerida por MICHEL \& KAUFMANN (1973), foram calculadas por VILLELA et al. (1991), para a temperatura de $25^{\circ} \mathrm{C}$, onde:

Potenciais Hídricos

$(\mathrm{MPa})$

$-0,04$

$-0,10$

$-0,20$

$-0,40$
Soluções Aquosas

( $\mathrm{g}$ de $\mathrm{PEG} / \mathrm{kg}$ de água destilada)
35,55

78,49

119,54

128,34

A dissolução do soluto em água destilada foi efetuada com 24 horas de antecedência à fase experimental. As soluções foram aplicadas sobre o substrato papel, em quantidade equivalente a 2,5 vezes o peso do papel, de acordo com as indicações de SILVA (1989). 


\subsubsection{Marcha de absorção de água}

Para cada lote, visando o estudo das marchas de absorção de água sob cada potencial hídrico do substrato, foram utilizadas quatro repetições de 25 sementes, com 90,110 e $130 \mathrm{~g}$ de água $/ \mathrm{kg}$, previamente pesadas em balança eletrônica Gehaka, modelo BG 440, de sensibilidade de $0,001 \mathrm{~g}$.

As sementes, de cada repetição, foram distribuidas entre duas camadas de seis folhas de papel toalha Germitest, umedecidas com $20 \mathrm{ml}$ da solução e dispostas sobre a tela de alumínio de cada caixa de plástico transparente $(10,6 \times 10,6 \times 3,0 \mathrm{~cm})$, do tipo "gerbox", adaptada para a condução do teste de envelhecimento acelerado de acordo com a proposta de ELLIOTT (1982). As caixas, tampadas e contendo $20 \mathrm{ml}$ de água no fundo, foram colocadas no interior de um germinador regulado para manter temperatura constante de $25^{\circ} \mathrm{C}$, em ausência de luz.

A partir da instalação, as caixas foram retiradas do germinador, em intervalos de 1 hora, para avaliação da absorção de água através da pesagem das sementes. A remoção das caixas ocorreu até quando foi verificada a estabilização da absorção de água e, ou, da emissão da raiz primária.

\subsubsection{Emissão de raiz primária}

Para cada lote, a avaliação da emissão de raiz primária sob cada potencial hídrico do substrato, foi realizada em conjunto com o estudo das marchas de absorção de água, conforme descrito em 3.5.1.

Após a remoção das caixas do germinador, em intervalos de 6 horas, as sementes de cada lote, com 90,110 e $130 \mathrm{~g}$ de água $/ \mathrm{kg}$, foram avaliadas visualmente em relação à ocorrência da emissão da raiz primária, computando-se as porcentagens de sementes que emitiram raiz primária. Os resultados médios obtidos foram representados graficamente. 


\subsubsection{Avaliação da proporção das sementes intumescidas}

Para cada lote, a avaliação da proporção de sementes intumescidas foi realizada em conjunto com o estudo das marchas de absorção de água, conforme descrito em 3.5.1. No entanto, neste caso, foi avaliada apenas a influência do potencial hídrico de $-0,04 \mathrm{MPa}$, em função da maior disponibilidade de água para as sementes.

As caixas foram removidas do germinador e após $2,4,6$, e 9 horas da instalação, as sementes, com 90,110 e $130 \mathrm{~g}$ de água $/ \mathrm{kg}$, foram classificadas por espessura, através da passagem em peneiras de crivos oblongos superpostas em ordem decrescente $(14 / 64 \times 3 / 4,13 / 64 \times 3 / 4$ da polegada), para contagem das retidas na peneira $14 / 64 \times 3 / 4$ da polegada. Este critério, adotado para caracterizar as sementes intumescidas, foi baseado em resultados de testes preliminares.

Os resultados foram expressos em porcentagem de sementes intumescidas ao final de cada período de absorção de água sob potencial hídrico de $-0,04 \mathrm{MPa}$ e, em seguida, procurou-se relacionar esses dados com os obtidos nas determinações laboratoriais realizadas após o umedecimento das sementes, conforme as descrições apresentadas em 3.4 .

\subsubsection{Avaliação dos danos por embebição}

A avaliação da ocorrência de possiveis danos por embebição foi realizada, em conjunto com o estudo das marchas de absorção, conforme descrito em 3.5.1., através da determinação da liberação de íons pelas sementes e da deteç̧ão de sintomas de deterioração por "umidade" após exposição das sementes ao tetrazólio.

\subsubsection{Liberação de íons}

A liberação de íons das sementes de cada lote, com 90,110 e $130 \mathrm{~g}$ de água $/ \mathrm{kg}$, foi avaliada após $2,4,6,9,12,18$ e 24 horas da instalação, sob potenciais hídricos do substrato de $-0,04 ;-0,10 ;-0,20$ e $-0,40 \mathrm{MPa}$, através da condutividade 
elétrica da solução, baseando-se nos procedimentos descritos por TILDEN \& WEST (1985).

Para isso, foram lavadas com $60 \mathrm{ml}$ de água destilada, tanto as folhas de papel Germitest das quatro repetições, que haviam sido umedecidas com diferentes concentrações de solução de PEG e utilizadas como substrato para embeber as 25 sementes, como as folhas de papel Germitest, de duas repetições de cada tratamento, que foram mantidas nas mesmas condições, ou seja, umedecidas com as mesmas soluções de PEG, porém que não receberam as sementes, de tal forma que foram designadas como provas em branco.

Após a lavagem das folhas, obtiveram-se soluções submetidas a análise da presença de íons, através de leitura em condutivímetro Digimed, modelo CD-20, baseando-se na metodologia proposta por LOEFFLER et al. (1988). Os resultados foram obtidos descontando do valor de leitura de cada amostra do valor médio de leitura das duas provas em branco e, expressos em $\mu \mathrm{mhos} / \mathrm{cm} / \mathrm{g}$ para cada amostra de semente com diferente teor de água, para cada potencial hídrico e cada lote.

\subsubsection{Deterioração por "umidade"}

Os sintomas de deterioração por "umidade" em sementes de cada lote, com 90, 110 e $130 \mathrm{~g}$ de água/kg, foram avaliados após 2, 4, 6, 9, 12 e 18 horas da instalação sob potenciais hídricos do substrato de $-0,04 ;-0,10 ;-0,20$ e $-0,40 \mathrm{MPa}$. Para isso, no entanto, as quatro repetições de 25 sementes foram agrupadas em 2 repetições de 50 sementes.

Para a detecção desses sintomas, as sementes foram submetidas a um tratamento de hidratação, sob condição de plena disponibilidade de água, por 18 horas, descontando o período anterior de absorção de água.

Este condicionamento consistiu em envolver as sementes em uma folha de papel toalha umedecida com a quantidade de água equivalente a 2,5 vezes o peso do papel, no interior de germinador Stults sob temperatura de $25^{\circ} \mathrm{C}$. Tal procedimento foi baseado nas informações de COSTA \& MARCOS FILHO (1994), segundo as quais o 
desenvolvimento da coloração suficientemente nítida para o exame adequado das áreas vitais das sementes e a identificação de sintomas de deterioração por "umidade" é obtido quando o teor de água está em torno de $320 \mathrm{~g} / \mathrm{kg}$ de sementes úmidas. Os demais procedimentos para a coloração no tetrazólio foram descritos anteriormente em 3.2.

Para a informação dos resultados, regristou-se o nível de viabilidade de cada amostra de sementes. Além disso, a dignose da deterioração por "umidade" foi efetuada através do exame das sementes consideradas viáveis, computando-se a ocorrência de tais danos em cada amostra de sementes, com diferente teor inicial de água, para cada potencial hídrico e cada lote.

\subsection{Avaliação da germinação das sementes}

Amostras de sementes de cada lote, com 90,110 e $130 \mathrm{~g}$ de água $/ \mathrm{kg}$, foram colocadas para germinar sob a influência de potenciais hídricos de $-0,04 ;-0,10$; $-0,20$ e $-0,40 \mathrm{MPa}$, através do umedecimento do papel para germinação com as respectivas soluções aquosas de polietilenoglicol, conforme descrição apresentada em 3.5.

A semeadura foi realizada utilizando-se quatro repetições de 25 sementes tratadas com fungicida. Estas sementes form distribuidas em substrato papel toalha Germitest, umedecido com as soluções citadas, na razão de 2,5 vezes o peso do papel no momento da instalação; o conjunto, após confecção dos rolos foi embalado em saco plástico e levado para germinador Stults, regulado à temperatura de $25^{\circ} \mathrm{C}$, em ausência de luz. A colocação dos rolos de papel em embalagem plástica teve por finalidade dificultar a perda de água por evaporação que, se agravada, demandaria constantes reposições de água e possíveis alterações, por elevação da concentração, nos potenciais húdricos das soluções, conforme as indicações de SILVA (1989).

Para cada lote, avaliaram-se a porcentagem de sementes que emitiram a raiz primária no terceiro dia da instalação, o vigor através da primeira contagem de plântulas normais no teste de germinação no quinto dia da instalação e a porcentagem de 
germinação obtida no sétimo de acordo com descrição encontrada nas Regras para Análise de Sementes (BRASIL, 1992).

\subsection{Avaliação da emergência de plântulas}

Este estudo foi instalado e conduzido no interior de caixas plásticas $(* 17,5$ $\times 12,0 \times 3,5 \mathrm{~cm}$ ). Para isso, foram utilizadas porções de terra fina seca ao ar (TFSa), retiradas de uma área localizada no Departamento de Agricultura da Escola Superior de Agricultura "Luiz de Queiroz", próxima ao Laboratório de Sementes, em solo classificado como Terra Roxa Estruturada Latossólica Eutrófica, textura argilosa, correspondente ao Kandiudalfic Eutrudox da classificação norte-americana (VIDALTORRADO \& SPAROVEK, 1993).

A terra foi retirada da porção superficial do solo (até $20 \mathrm{~cm}$ de profundidade) e, após secagem ao ar e peneiração para eliminação de torrões e uniformização, foi armazenada num depósito apropriado até o momento de sua utilização.

Antes da instalação, foi realizada a avaliação das características fisicas e químicas, a elaboração da curva de retenção de água e a determinação do teor de água da terra. A avaliação das características químicas e fisicas da terra foi realizada após a coleta de duas amostras de aproximadamente $1000 \mathrm{~g}$ de TFSA e envio das mesmas para o Departamento de Ciência do Solo. Os resultados da análise das características químicas e físicas estão apresentados na Tabela 1. A terra utilizada para o estudo das relações entre o teor de água e a emergência das plântulas sob a influência de diferentes potenciais hídricos, pode ser considerada favorável, pois apresentava nivel adequado de nutrientes e ausência de alumínio tóxico.

Para a determinação da densidade da terra a ser mantida posteriormente nas caixas e para a elaboração da curva de retenção de água, que se refere à relação funcional entre o teor de água da terra e o potencial mátrico, obtida com base na equação proposta por VAN GENUCHTEN (1985), amostras de terra foram colocadas em caixas plásticas e enviadas ao Instituto de Pesquisas Tecnológicas (IPT). 
A determinação do teor de água foi realizada após a coleta de quatro amostras de aproximadamente $100 \mathrm{~g}$ de TFSA. Estas foram pesadas e levadas para secar em estufa a $105^{\circ} \mathrm{C}$, por 24 horas e, em seguida, foram novamente pesadas para o cálculo do teor de água. Os valores obtidos em umidade à base de massa seca $(\mathrm{g} / \mathrm{g}$,) foram transformados, considerando a densidade da terra $\left(\mathrm{g} / \mathrm{cm}^{3}\right)$, em umidade à base de volume $\left(\mathrm{cm}^{3} / \mathrm{cm}^{3}\right)$.

\subsubsection{Preparo das caixas para a instalação}

Para a obtenção dos potenciais hídricos desejados, determinou-se a quantidade de terra e a de água a ser adicionada em cada caixa plástica.

Para a determinação da quantidade de terra a ser adicionada, mediu-se o volume de cada caixa plástica $\left(\mathrm{cm}^{3}\right)$ e através de cálculos, considerando densidade $\left(\mathrm{g} / \mathrm{cm}^{3}\right)$ e teor inicial de água da terra $(\mathrm{g} / \mathrm{g})$, obteve-se, conforme apresentado na Tabela 2, a quantidade de terra a ser colocada por caixa. Esta quantidade foi pesada em balança MARTE, modelo 5000 com precisão de $0,1 \mathrm{~g}$.

Considerando o teor de água inicial da terra $\left(\mathrm{cm}^{3} / \mathrm{cm}^{3}\right)$, o volume de cada caixa plástica $\left(\mathrm{cm}^{3}\right)$ e o teor de água correspondente a cada potencial hídrico desejado $\left(\mathrm{cm}^{3} / \mathrm{cm}^{3}\right)$, conforme apresentado na Figura 1, determinou-se a quantidade de água a ser adicionada por caixa (Tabela 3 ).

Determinada a quantidade de água a ser adicionada por caixa, realizou-se a adição de água à terra, com cuidado para que se pudesse obter um teor de água uniforme. Estas caixas foram cobertas com tampas plásticas e permaneceram em câmara fria por 24 horas, para uniformização.

\subsubsection{Semeadura}

Para cada lote, foram instaladas cinco repetições de 10 sementes, com teores iniciais de água de 90,110 e $130 \mathrm{~g} / \mathrm{kg}$, sob a influência de potenciais hídricos do 
substrato de $-0,04 ;-0,10 ;-0,20$ e $-0,40 \mathrm{MPa}$, obtidos conforme informações apresentadas na curva de retenção de água da terra (Figura 1).

Estas sementes foram distribuidas a uma profundidade de $2,0 \mathrm{~cm} \mathrm{e}$, em seguida, o conjunto foi levado para germinador, à temperatura de $25^{\circ} \mathrm{C}$ e $94 \%$ de umidade relativa do ar. Estas caixas foram mantidas tampadas, conforme testes preliminares, visando evitar que os teores de água na terra sofressem variações diárias decorrentes da evaporação, além da absorção de água pelas sementes.

Para cada lote, separadamente para cada amostra de sementes, foi determinado o indice de velocidade de emergência das plântulas, através da somatória do número de plântulas emergidas em cada dia dividido pelo número de dias decorridos entre a semeadura e a emergência (MARCOS FILHO et al. 1987). Para isso, a emergência foi caracterizada pelo aparecimento dos cotilédones acima da superfície da terra, baseando-se na caracterização do estádio VE, descrita por COSTA \& MARCHEZAN (1982) e no comprimento do hipocótilo, superior a $3 \mathrm{~cm}$.

Além desta avaliação, foi realizada, em conjunto com a determinação do índice de velocidade de emergência, a avaliação da porcentagem de plântulas emergidas por ocasião da estabilização da emergência, de acordo com a descrição apresentada por MARCOS FILHO et al. (1987). 


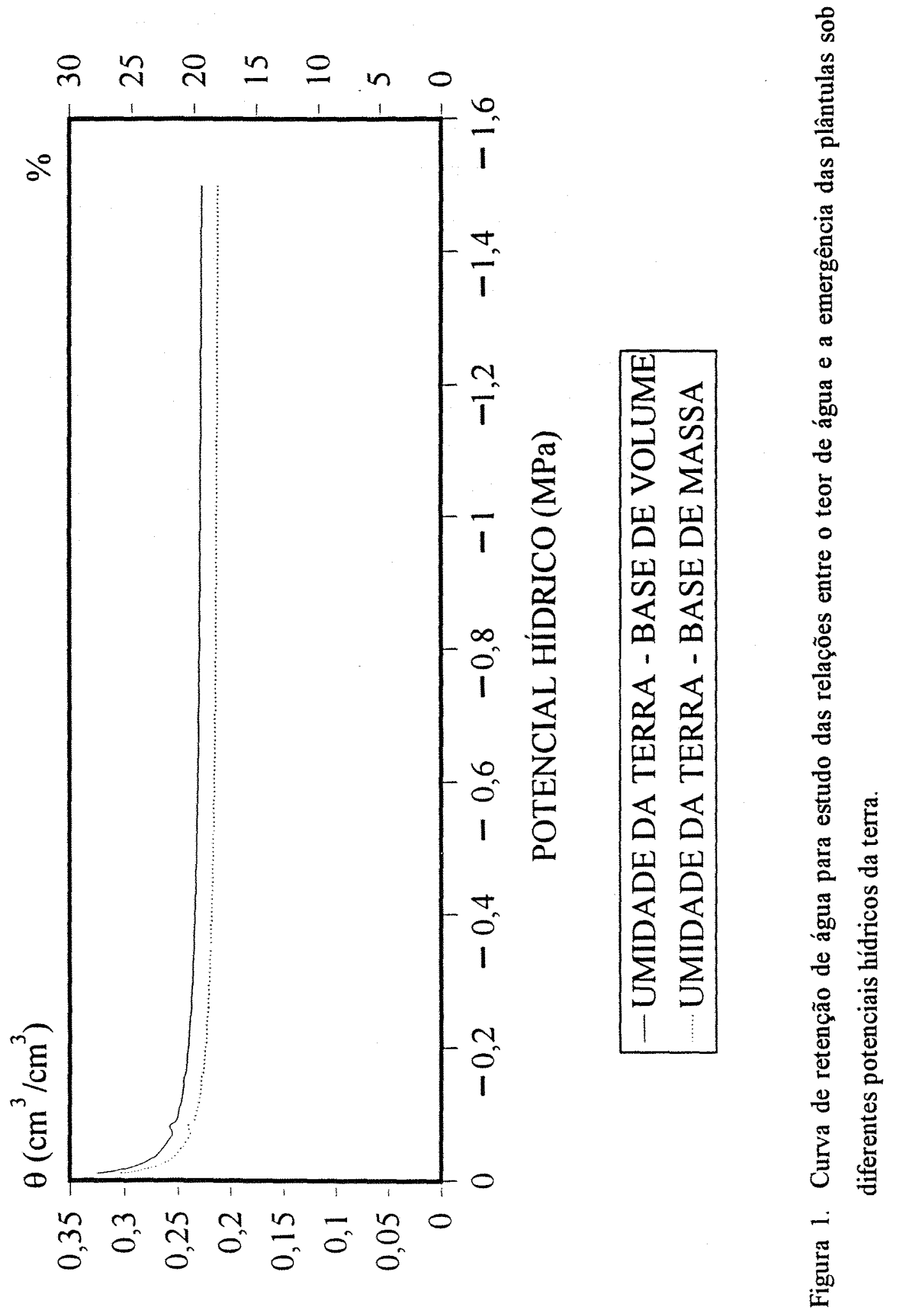


Tabela 1. Características químicas e fisicas da terra utilizada para o estudo das relações entre o teor de água e emergência das plântulas sob a influência de diferentes potenciais hídricos.

\begin{tabular}{|c|c|c|c|c|c|c|}
\hline \multirow[t]{2}{*}{$\mathrm{pH}$ em $\mathrm{CaCl}_{2}$} & MO & $\mathbf{P}$ & $\mathrm{S}-\mathrm{SO}_{4}$ & Areia & Silte & Argila \\
\hline & $\%$ & \multicolumn{2}{|c|}{$\mu \mathrm{g} / \mathrm{cm}^{3}$} & $\%$ & $\%$ & $\%$ \\
\hline 5.1 & 2.1 & 24 & 17.62 & 28 & 18 & 54 \\
\hline $\mathrm{K}$ & $\mathrm{Ca}$ & $\mathrm{Mg}$ & $\mathrm{H}+\mathrm{Al}$ & Al. & SB & $\mathrm{T}$ \\
\hline \multicolumn{7}{|c|}{$\mathrm{meq} / 100 \mathrm{~cm}^{3}$} \\
\hline 0.40 & 5.8 & 2.0 & 6.4 & 0.0 & 8.2 & 14.6 \\
\hline
\end{tabular}

Tabela 2. Determinação da quantidade de terra a ser adicionada por caixa plástica.

\begin{tabular}{cccc}
\hline $\begin{array}{c}\text { Volume da caixa } \\
\mathrm{cm}^{3}\end{array}$ & $\begin{array}{c}\text { Densidade da Terra } \\
\mathrm{g} / \mathrm{cm}^{3}\end{array}$ & $\begin{array}{c}\text { Teor inicial de água } \\
\mathrm{g} / \mathrm{g}\end{array}$ & $\begin{array}{c}\text { Quantidade de Terra } \\
\mathrm{g}\end{array}$ \\
\hline 650 & 1.25 & 0.046 & 849.9 \\
\hline
\end{tabular}


Tabela 3. Determinação da quantidade de água a ser adicionada por caixa plástica.

\begin{tabular}{cccccccc}
\hline \multirow{2}{*}{$\begin{array}{c}\text { Potenciais } \\
\text { hidricos } \\
\text { desejados }\end{array}$} & $\begin{array}{c}\text { Teores de água } \\
\text { Correspondentes }\end{array}$ & & $\begin{array}{c}\text { Teor inicial de } \\
\text { água na terra }\end{array}$ & $\begin{array}{c}\text { Quantidade de } \\
\text { água na Terra }\end{array}$ & $\begin{array}{c}\text { Quantidade de } \\
\text { água a ser } \\
\text { adicionada }\end{array}$ \\
\cline { 2 - 4 } & $\mathrm{g} / \mathrm{g}$ & $\mathrm{cm}^{3} / \mathrm{cm}^{3}$ & $\mathrm{~g} / \mathrm{g}$ & $\mathrm{cm}^{3} / \mathrm{cm}^{3}$ & $\mathrm{~g}$ & $\mathrm{~cm}^{3}$ \\
\hline-0.04 & 0.21462 & 0.26827 & 0.046 & 0.0575 & 37.3 & 137.00 \\
-0.10 & 0.19920 & 0.24900 & 0.046 & 0.0575 & 37.3 & 124.47 \\
-0.20 & 0.19184 & 0.23984 & 0.046 & 0.0575 & 37.3 & 118.52 \\
-0.40 & 0.18694 & 0.23367 & 0.046 & 0.0575 & 37.3 & 114.51 \\
\hline
\end{tabular}

\subsection{Procedimento estatístico}

A análise estatística dos dados foi realizada no sistema de análise estatística para microcomputadores SANEST (ZONTA et al., 1984), separadamente para cada variável e cada lote. No entanto, os dados referentes à determinação do teor de água das sementes não foram analisados estatisticamente. Além disso, os dados correspondentes à avaliação da emissão de raiz primária e à absorção de água das sementes, após cada período de embebição sob a influência de diferentes potenciais hídricos do substrato apenas foram apresentados graficamente.

A instalação do estudo para caracterização dos lotes obtidos após envelhecimento artificial obedeceu ao delineamento inteiramente casualizado, com 4 repetições (Tabela 4). Para os demais estudos, o delineamento experimental foi o inteiramente casualizado, em esquema fatorial, com número variado de repetições conforme o parâmetro avaliado; cujos esquemas utilizados para a análise da variância estão apresentados nas Tabelas 5 a 8 . Nos casos em que a interação entre 2 fatores foi significativa, verificou-se os efeitos de um fator dentro de outro. 
As diversas variáveis, expressas em porcentagem, foram transformadas, previamente, em arc seno $\sqrt{x / 100}$; porém, os resultados foram apresentados através das médias dos dados originais, com a finalidade de facilitar a visualização e a interpretação.

A comparação múltipla das médias foi efetuada através do teste de Tukey, ao nível de $5 \%$ de probabilidade.

Tabela 4. Esquema da análise da variância dos dados resultantes dos testes de germinação, envelhecimento acelerado, condutividade elétrica, tetrazólio e peso de 1000 sementes para caracterização dos lotes de sementes de soja do cultivar IAC-15.

\begin{tabular}{lccccc}
\hline $\begin{array}{l}\text { Causas da } \\
\text { Variação }\end{array}$ & Graus de Liberdade \\
\cline { 2 - 6 } & Germinação & $\begin{array}{l}\text { Condutividade } \\
\text { Elétrica }\end{array}$ & $\begin{array}{l}\text { Envelhecimento } \\
\text { Acelerado }\end{array}$ & Tetrazólio & $\begin{array}{l}\text { Peso de 1000 } \\
\text { Sementes }\end{array}$ \\
\hline \multirow{2}{*}{$\begin{array}{l}\text { Lotes } \\
\text { Residuo }\end{array}$} & 2 & 2 & 2 & 2 & 2 \\
& 9 & 9 & 9 & 9 & 21 \\
\hline Total & 11 & 11 & 11 & 11 & 23 \\
\hline
\end{tabular}


Tabela 5. Esquema da análise da variância dos dados resultantes dos testes de germinação, envelhecimento acelerado, condutividade elétrica, tetrazólio e peso de 1000 sementes realizados após umedecimento artificial de 3 lotes de sementes de soja do cultivar IAC-15.

\begin{tabular}{lccccc}
\hline Causas da & \multicolumn{5}{c}{ Graus de Liberdade } \\
\cline { 2 - 5 } & Germinação & $\begin{array}{l}\text { Condutividade } \\
\text { Elétrica }\end{array}$ & $\begin{array}{l}\text { Envelhecimento } \\
\text { Acelerado }\end{array}$ & Tetrazólio & $\begin{array}{l}\text { Peso de 1000 } \\
\text { Sementes }\end{array}$ \\
\hline Lotes (L) & 2 & 2 & 2 & 2 & 2 \\
Teores de água (A) & 2 & 2 & 2 & 2 & 2 \\
Lx A & 4 & 4 & 4 & 4 & 4 \\
Residuo & 27 & 27 & 27 & 27 & 63 \\
\hline Total & 35 & 35 & 35 & 35 & 71 \\
\hline
\end{tabular}

Tabela 6. Esquema da análise da variância dos dados resultantes da avaliação das sementes intumescidas após exposição a determinados períodos de absorção de água sob a influência de potencial hídrico de $-0,04 \mathrm{MPa}$, denominados Tratamentos, separadamente para cada lote.

Causas da variação $\quad$ Graus de Liberdade

Tratamentos (T)

Teores de água (A)

3

$\mathrm{T} \times \mathrm{A}$

2

Resíduo 
Tabela 7. Esquema da análise da variância dos dados resultantes da avaliação dos danos por embebição das sementes com diferentes teores de água, através da deteç̧ão da liberação de íons e da identificação dos sintomas de deterioração por "umidade", após determinados períodos de absorção de água, separadamente para cada potencial hídrico do substrato, para cada lote.

\begin{tabular}{lcc}
\hline Causas da Variação & \multicolumn{2}{c}{ Graus de Liberdade } \\
\cline { 2 - 3 } & Liberação de íons & Deterioração por "umidade" \\
\hline & 6 & 5 \\
Períodos de absorção de água (P) & 2 & 2 \\
Teores de água (A) & 12 & 10 \\
P X A & 63 & 55 \\
Residuo & & 71 \\
\hline Total & 83 & 71 \\
\hline
\end{tabular}

Tabela 8. Esquema da análise da variância dos dados resultantes da avaliação das relações entre o teor de água e germinação das sementes ou emergência das plântulas sob a influência de diferentes potenciais hídricos do substrato, respectivamente, papel e terra, para cada lote.

\begin{tabular}{lcc}
\hline \multirow{2}{*}{ Causas da Variação } & \multicolumn{2}{c}{ Graus de Liberdade } \\
\cline { 2 - 3 } & Germinação de sementes & Emergência de plântulas \\
\hline \multirow{2}{*}{ Potencial hídrico $(\mathrm{H})$} & 3 & 3 \\
Teores de água $(\mathrm{A})$ & 2 & 2 \\
H x A & 6 & 6 \\
Residuo & 36 & 48 \\
& & 59 \\
\hline Total & 47 & 59 \\
\hline
\end{tabular}




\section{RESULTADOS E DISCUSSÃo}

\subsection{Caracterização dos lotes}

Esta etapa teve por finalidade detectar as diferenças de qualidade fisiológica entre os lotes obtidos após envelhecimento artificial e, ao mesmo tempo, atuar como fonte de explicações para o comportamento das sementes frente a diferentes situações de teor de água da semente e de disponibilidade hídrica do substrato.

Pela Tabela 9, onde estão apresentados os resultados das análises da variância dos dados referentes aos testes para avaliação da qualidade fisiológica das sementes, observaram-se valores de $\mathrm{F}$ altamente significativos para os efeitos de Lotes sobre a germinação e o vigor das sementes.

Quando o vigor foi avaliado pelo teste de tetrazólio (Tabela 10), observaram-se valores de $\mathrm{F}$ significativos para os efeitos de Lotes. Por outro lado, não ocorreram efeitos significativos para Lotes na determinação do peso de 1000 sementes (Tabela 9) e no teste de tetrazólio, quando avaliaram-se a viabilidade e os sintomas de deterioração por "umidade"(Tabela 10).

Os dados médios obtidos, para detectar as diferenças de qualidade fisiológica entre os lotes durante os testes preliminares, são apresentados na Tabela 11. Os dados referentes ao grau de umidade das sementes, embora não tenham sido analisados estatisticamente, foram, de um modo geral, semelhantes para os três lotes estudados. O teor esteve entre 91 e $98 \mathrm{~g}$ de água $/ \mathrm{kg}$ de sementes úmidas; este fato é importante na execução dos testes, considerando-se que a uniformização do teor de água das sementes é imprescindível para a padronização das avaliações e obtenção de resultados consistentes (MARCOS FILHO et al., 1987). 
Tabela 9. Valores de $\mathrm{F}$ obtidos nas análises da variância dos dados referentes às determinações preliminares (peso de 1000 sementes, germinação, primeira contagem, condutividade elétrica e envelhecimento acelerado), realizadas para caracterização dos lotes de sementes de soja.

\begin{tabular}{cccccc}
\hline Causas da Variação & $\begin{array}{c}\text { Peso de 1000 } \\
\text { Sementes } \\
(\mathrm{g})\end{array}$ & $\begin{array}{c}\text { Germinação } \\
(\%)\end{array}$ & $\begin{array}{c}\text { Primeira } \\
\text { Contagem } \\
(\%)\end{array}$ & $\begin{array}{c}\text { Condutividade } \\
\text { Elétrica } \\
(\text { umhos/cm/g) }\end{array}$ & $\begin{array}{c}\text { Envelhecimento } \\
\text { Acelerado } \\
(\%)\end{array}$ \\
\hline Lotes & $1.8639^{n \mathrm{~ns}}$ & $16.2068^{* *}$ & $47.9746^{* *}$ & $34.5101^{* *}$ & $43.9952^{* *}$ \\
\hline
\end{tabular}

${ }^{*}$ significativo ao nível de $5 \%$ de probabilidade; ${ }^{* *}$ significativo ao nível de $1 \%$ de probabilidade; ns não significativo

Tabela 10. Valores de F obtidos na análise da variância dos dados referentes ao teste de tetrazólio (vigor $=T Z$ 1-3, viabilidade $=T Z 1-5$ e deterioração por "umidade"= TZ 1-5 e TZ 6- 8), realizadas para caracterização dos lotes de sementes de soja.

\begin{tabular}{cccccc}
\hline Causas da Variação & \multicolumn{2}{c}{ Tetrazólio } & & \multicolumn{2}{c}{ Deterioração por "umidade" } \\
\cline { 2 - 5 } \cline { 5 - 6 } & $\begin{array}{c}\text { Vigor } \\
(\%)\end{array}$ & $\begin{array}{c}\text { Viabilidade } \\
(\%)\end{array}$ & & $\begin{array}{c}\text { Viáveis } \\
(\%)\end{array}$ & $\begin{array}{c}\text { Não vía veis } \\
(\%)\end{array}$ \\
\hline Lotes & $14.6410^{*}$ & $4.5456^{\mathrm{ns}}$ & & $1.4333^{\mathrm{ns}}$ & $3.1813 \mathrm{~ns}$ \\
\hline
\end{tabular}

* significativo ao nível de $5 \%$ de probabilidade; ${ }^{* *}$ significativo ao nível de $1 \%$ de probabilidade; ns não significativo 
Examinando-se a Tabela 11, observou-se que na avaliação do peso de 1000 sementes, não houve diferenças significativas entre as médias. Pelos resultados de germinação, notou-se que o lote 1 foi superior aos outros dois, embora não tenha sido estatisticamente diferente do lote 2 .

Os testes de primeira contagem e de envelhecimento acelerado reveleram o melhor desempenho do lote 1 em relação ao lote 2 e deste em relação ao lote 3 (Tabela 11). Porém, os testes de condutividade elétrica e tetrazólio (TZ 1-3), mostraram que o lote 1 foi superior aos lotes 2 e 3 , semelhantes entre si, concordando com HEPBURN et al. (1984), que realizando avaliações de condutividade elétrica, individualmente e de massa, em sementes de soja e ervilha, evindenciaram que ocorreu uma sobreposição entre a condutividade elétrica de lotes de sementes com diferentes níveis de vigor, de tal forma que não foi possível uma separação eficiente entre os mesmos e, constataram ainda que, esta sobreposição foi menor nos estudos com sementes individuais. No entanto, MARCOS FILHO et al. (1985); BARROS (1988) e DIAS (1994) ressaltaram a eficiência do teste de condutividade elétrica na identificação de lotes com diferentes níveis de qualidade e potencial de emergência de plântulas.

Observou-se, ainda na Tabela 11, que não houve diferenças significativas entre os lotes no teste de tetrazólio, quando avaliaram-se a viabilidade (TZ 1-5) e os sintomas de deterioração por "umidade" nas sementes viáveis (TZ 1-5) e nas sementes não viáveis (TZ 6-8), embora tenha sido verificada uma tendência das sementes do lote 1 apresentarem-se com sintomas de deterioração por "umidade" menos intensos em relação às dos lotes 2 e 3 . Portanto, o envelhecimento artificial não ocasionou mudanças a nível de ocasionar a deterioração por "umidade" através do teste de tetrazólio.

De modo geral, os dados indicaram que praticamente todos os testes, utilizados para avaliar a qualidade fisiológica dos lotes, detectaram a superioridade do lote 1 e a inferioridade do lote 3 , embora a germinação do lote 1 tenha sido semelhante à do lote 2 e, os lotes 2 e 3 não tenham diferido entre si pelos resultados dos testes de condutividade elétrica e tetrazólio (TZ 1-3). 
Tabela 11. Dados médios obtidos nos testes preliminares de grau de umidade, peso de 1000 sementes, germinação, primeira contagem e condutividade elétrica, envelhecimento acelerado, tetrazólio (vigor $=\mathrm{TZ} 1-3$, viabilidade $=\mathrm{TZ} 1-5 \mathrm{e}$ deterioração por "umidade" nas sementes viavéis - TZ 1-5 e nas sementes não viáveis - TZ 6- 8) e respectivos coeficientes de variação.

\begin{tabular}{|c|c|c|c|c|c|}
\hline Lotes & $\begin{array}{c}\text { Teor inicial de } \\
\text { água } \\
(\mathrm{g} / \mathrm{kg})\end{array}$ & $\begin{array}{l}\text { Peso de } 1000 \\
\text { sementes } \\
(\mathrm{g})\end{array}$ & $\begin{array}{c}\text { Germinação } \\
(\%)\end{array}$ & $\begin{array}{c}\text { Primeira } \\
\text { Contagem } \\
(\%)\end{array}$ & $\begin{array}{l}\text { Condutividade } \\
\text { Elétrica } \\
\text { (umhos } / \mathrm{cm} / \mathrm{g} \text { ) }\end{array}$ \\
\hline 1 & 91 & $140.0 \mathrm{a}$ & $92.0 \mathrm{a}$ & $88.0 \mathrm{a}$ & $70.2 \mathrm{a}$ \\
\hline 2 & 94 & $141.0 \mathrm{a}$ & $89.0 \mathrm{a}$ & $80.0 \mathrm{~b}$ & $107.8 \mathrm{~b}$ \\
\hline 3 & 98 & $142.0 \mathrm{a}$ & $80.0 \mathrm{~b}$ & $64.0 \mathrm{c}$ & $116.9 \mathrm{~b}$ \\
\hline C.V. $(\%)$ & & 0.7 & 3.7 & 3.9 & 8.6 \\
\hline \multirow[t]{2}{*}{ Lotes } & \multirow{2}{*}{$\begin{array}{c}\text { Envelhecimento } \\
\text { Acelerado } \\
(\%)\end{array}$} & \multicolumn{2}{|c|}{ Tetrazólio } & \multicolumn{2}{|c|}{ Deterioração por "umidade" } \\
\hline & & $\begin{array}{l}\text { Vigor } \\
(\%)\end{array}$ & $\begin{array}{c}\text { Viabilidade } \\
(\%)\end{array}$ & $\begin{array}{c}\text { Viáveis } \\
(\%)\end{array}$ & $\begin{array}{c}\text { Não viavéis } \\
(\%)\end{array}$ \\
\hline 1 & $88.0 \mathrm{a}$ & $92.0 \mathrm{a}$ & $96.0 \mathrm{a}$ & $70.0 \mathrm{a}$ & $1.0 \mathrm{a}$ \\
\hline 2 & $76.0 \mathrm{~b}$ & $84.0 \mathrm{~b}$ & $93.0 \mathrm{a}$ & $73.0 \mathrm{a}$ & $2.0 \mathrm{a}$ \\
\hline 3 & $60.0 \mathrm{c}$ & $82.0 \mathrm{~b}$ & $88.0 \mathrm{a}$ & $74.0 \mathrm{a}$ & $5.0 \mathrm{a}$ \\
\hline C.V. $(\%)$ & 4.7 & 2.5 & 4.0 & 2.7 & 41.8 \\
\hline
\end{tabular}

Letras minúsculas: comparações entre médias dentro de cada coluna.

Assim, após o envelhecimento artificial, os lotes apresentaram a característica básica de germinação de, no mínimo, 80\% e diferentes níveis de vigor. Este procedimento foi eficiente para a obtenção de lotes de mesmo histórico de produção, porém, com diferentes níveis de vigor, à semelhança de TILDEN \& WEST (1985), que também simularam diferentes níveis de vigor utilizando os procedimentos do teste de envelhecimento acelerado. No entanto, deve ser destacado que, embora os efeitos do "envelhecimento natural" e das condições impostas durante o envelhecimento artificial se traduzam na queda do poder germinativo e, ou, morte das sementes, ambos não agem de maneira semelhante sobre o metabolismo, conforme destacaram vários autores, dentre os 
quais ADBUL-BAKI \& ANDERSON (1972); PRIESTLEY \& LEOPOLD (1983); GANGULI \& SEN-MANDI (1990); MARCOS FILHO (1994).

\subsection{Caracterização das sementes após umedecimento artificial}

Esta etapa teve por finalidade caracterizar a qualidade fisiológica dos 3 lotes de sementes com 90, 110 e $130 \mathrm{~g}$ de água $/ \mathrm{kg}$ de sementes úmidas. Examinando-se os valores de $\mathrm{F}$ obtidos nas análises da variância (Tabela 12), verificou-se que ocorreram efeitos altamente significativos para Lotes e para Teores de Água em todas as avaliações, exceto para Lotes sobre o peso de 1000 sementes. Além disso, também verificou-se que ocorreu efeito significativo, a nível de $5 \%$ de probabilidade, para a interação Lotes $x$ Teores de água nos testes de condutividade elétrica e de envelhecimento acelerado.

Pela Tabela 13, observa-se que ocorreram efeitos altamente significativos apenas para Lotes no teste de tetrazólio e na avaliação da deterioração por "umidade".

Tabela 12. Valores de F obtidos nas análises da variância dos dados referentes aos testes (peso de 1000 sementes, germinação, primeira contagem, condutividade elétrica e envelhecimento acelerado), após o umedecimento artificial das sementes de soja.

\begin{tabular}{|c|c|c|c|c|c|}
\hline Causas da Variação & $\begin{array}{l}\text { Peso de } 1000 \\
\text { Sementes } \\
(\mathrm{g})\end{array}$ & $\begin{array}{c}\text { Germinação } \\
(\%)\end{array}$ & $\begin{array}{l}\text { Primeira } \\
\text { Contagem } \\
(\%)\end{array}$ & $\begin{array}{l}\text { Condutividade } \\
\text { Elétrica } \\
\text { (umhos } / \mathrm{cm} / \mathrm{g} \text { ) }\end{array}$ & $\begin{array}{c}\text { Envelhecimento } \\
\text { Acelerado } \\
(\%)\end{array}$ \\
\hline Lotes $(\mathrm{L})$ & $1.1967^{\mathrm{ns}}$ & $34.2383^{* *}$ & $133.8466^{* *}$ & $113.3594^{* *}$ & $104.4573^{* *}$ \\
\hline Teores de água (A) & $204.1744^{* *}$ & $9.4445^{* *}$ & $6.2708^{* *}$ & $48.8147^{* *}$ & $18.2735^{* *}$ \\
\hline $\mathrm{L} \times \mathrm{A}$ & $1.3869^{\mathrm{ns}}$ & $2.1323^{\mathrm{ns}}$ & $1.2688^{\mathrm{nS}}$ & $5.0981^{*}$ & $3.3659^{*}$ \\
\hline
\end{tabular}

\footnotetext{
${ }^{*}$ significativo ao nível de $5 \%$ de probabilidade; ${ }^{* *}$ significativo ao nível de $1 \%$ de probabilidade; ns não significativo
} 
Tabela 13. Valores de F obtidos nas análises da variância dos dados referentes ao teste de tetrazólio (vigor, viabilidade e deterioração por "umidade"), após o umedecimento artificial das sementes de soja.

\begin{tabular}{lccccc}
\hline \multirow{2}{*}{ Causas da Variação } & \multicolumn{2}{c}{ Tetrazólio } & & \multicolumn{2}{c}{ Deterioração por "umidade" } \\
\cline { 2 - 3 } & $\begin{array}{c}\text { Vigor } \\
(\%)\end{array}$ & $\begin{array}{c}\text { Viabilidade } \\
(\%)\end{array}$ & & $\begin{array}{c}\text { Viáveis } \\
(\%)\end{array}$ & $\begin{array}{c}\text { Não viáveis } \\
(\%)\end{array}$ \\
\hline Lotes (L) & $30.2937^{* *}$ & $18.8310^{* *}$ & & $9.3147^{* *}$ & $33.5298^{* *}$ \\
Teores de água (A) & $1.5834^{\mathrm{ns}}$ & $1.3962^{\mathrm{ns}}$ & & $2.7085^{\mathrm{ns}}$ & $1.9406^{\mathrm{ns}}$ \\
LxA & $0.7701^{\mathrm{ns}}$ & $0.3569^{\mathrm{ns}}$ & & $0.2031^{\mathrm{ns}}$ & $0.6890^{\mathrm{ns}}$ \\
\hline
\end{tabular}

* significativo ao nível de $5 \%$ de probabilidade; ${ }^{* *}$ significativo ao nivel de $1 \%$ de probabilidade; ns não significativo

Os dados médios obtidos, para caracterizar a qualidade fisiológica das sementes dos três lotes, com diferentes teores de água, acham-se apresentados nas Tabelas 14 a 22. Observou-se que na avaliação do peso de 1000 sementes, não houve diferenças significativas entre os lotes. Além disso, as sementes dos três lotes, com menor teor de água, $90 \mathrm{~g} / \mathrm{kg}$ de sementes úmidas. foram as que apresentaram também o menor peso de 1000 sementes (Tabela 14).

A germinação do lote I foi significativamente superior à do lote 2,0 mesmo ocorrendo com esta em relação à do lote 3. De modo geral, as sementes mais úmidas, com $130 \mathrm{~g}$ de água/kg, apresentaram germinação significativamente mais elevada em relação às demais, que não diferiram estatisticamente entre si (Tabela 15). Essas mesmas observações com variações pouco acentuadas, podem ser aplicadas para o teste de primeira contagem de germinação (Tabela 17).

Pela Tabela 16, constatou-se que a viabilidade (TZ 1-5) do lote 1 foi superior à do lote 2 , à semelhança da informação constatada no teste de germinação (Tabela 15), concordando com PASHA \& DAS (1982) que também encontraram uma clara associação entre os resultados de germinação e tetrazólio (vigor? *-TZ 1-3). Porém, 
a viabilidade do lote 2 não diferiu daquela do lote 3 , como tinha sido observada no teste de germinação (Tabela 15). Comparando-se os resultados de viabilidade (TZ 1-5) com os de germinação (Tabela 15), observaram-se pequenas diferenças em termos numéricos a favor do teste de tetrazólio, sendo que segundo FRANÇA NETO et al. (1988), diferenças de até $5 \%$ entre os 2 testes para sementes de soja podem ser consideradas normais. Além disso, o grau de umidade das sementes não interferiu na viabilidade das sementes dos três lotes.

Tabela 14. Peso de 1000 sementes: valores médios (g) obtidos para os três lotes de sementes de soja do cultivar IAC-15, com teores de água ajustados, e coeficiente de variação.

\begin{tabular}{cllll}
\hline & \multicolumn{3}{c}{ Teores de água (g/kg de sementes) } & \\
\cline { 2 - 4 } Lotes & 90 & 110 & 130 & Médias \\
\hline 1 & 140.6 & 143.6 & 147.4 & $143.9 \mathrm{a}$ \\
2 & 141.1 & 143.8 & 147.3 & $144.1 \mathrm{a}$ \\
3 & 141.6 & 144.5 & 146.9 & $144.3 \mathrm{a}$ \\
\hline Médias & $141.1 \mathrm{C}$ & $144.0 \mathrm{~B}$ & $147.2 \mathrm{~A}$ & \\
\hline C.V.(\%) & 0.7 & & & \\
\hline
\end{tabular}

Letras minúsculas: comparações entre médias dentro de cada coluna.

Letra maiúsculas: comparações entre médias dentro de cada linha. 
Tabela 15. Germinação: valores médios (\%) obtidos para os três lotes de sementes de soja do cultivar IAC-15, com teores de água ajustados, e coeficiente de variação.

\begin{tabular}{cllll}
\hline & \multicolumn{3}{c}{ Teores de água $(\mathrm{g} / \mathrm{kg}$ de sementes $)$} & \\
\cline { 2 - 5 } Lotes & 90 & 110 & 130 & Médias \\
\hline 1 & 92 & 94 & 95 & $94 \mathrm{a}$ \\
2 & 89 & 91 & 91 & $90 \mathrm{~b}$ \\
3 & 80 & 82 & 90 & $84 \mathrm{c}$ \\
\hline Médias & $87 \mathrm{~B}$ & $89 \mathrm{~B}$ & $92 \mathrm{~A}$ & \\
\hline C.V.(\%) & 3.4 & & & \\
\hline
\end{tabular}

Letras minúsculas: comparações entre médias dentro de cada coluna.

Letra maiúsculas: comparações entre médias dentro de cada linha.

Tabela 16. Viabilidade (TZ 1-5): valores médios (\%) obtidos para os três lotes de sementes de soja do cultivar IAC-15, com teores de água ajustados, e coeficiente de variação.

\begin{tabular}{clllc}
\hline & \multicolumn{3}{c}{ Teores de água $(\mathrm{g} / \mathrm{kg}$ de sementes $)$} & \\
\cline { 2 - 5 } Lotes & 90 & 110 & 130 & Médias \\
\hline 1 & 96 & 97 & 98 & $97 \mathrm{a}$ \\
2 & 93 & 93 & 93 & $93 \mathrm{~b}$ \\
3 & 88 & 90 & 92 & $90 \mathrm{~b}$ \\
\hline Médias & $92 \mathrm{~A}$ & $93 \mathrm{~A}$ & $94 \mathrm{~A}$ & \\
\hline C.V.(\%) & 3.3 & & & \\
\hline
\end{tabular}

Letras minúsculas: comparações entre médias dentro de cada coluna.

Letras maiusculas: comparações entre médias dentro de cada linha. 
Tabela 17. Primeira contagem do teste de germinação: valores médios (\%) obtidos para os três lotes de sementes de soja do cultivar IAC-15, com teores de água ajustados, e coeficiente de variação.

\begin{tabular}{ccccc}
\hline & \multicolumn{3}{c}{ Teores de água ( $\mathrm{g} / \mathrm{kg}$ de sementes) } & \\
\cline { 2 - 5 } Lotes & 90 & 110 & 130 & Médias \\
\hline 1 & 88 & 90 & 90 & $89 \mathrm{a}$ \\
2 & 80 & 83 & 84 & $82 \mathrm{~b}$ \\
3 & 64 & 66 & 73 & $68 \mathrm{c}$ \\
\hline Médias & $77 \mathrm{~B}$ & $80 \mathrm{AB}$ & $82 \mathrm{~A}$ & \\
\hline C.V.(\%) & 3.7 & & & \\
\hline
\end{tabular}

Letras minúsculas: comparações entre médias dentro de cada coluna.

Letras maiusculas: comparações entre médias dentro de cada linha.

Pela Tabela 18 referente à condutividade elétrica, constatou-se a superioridade do lote 1 em relação aos lotes 2 e 3 , à semelhança do observado nos testes de germinação e de primeira contagem. Para o lote 1 , o teor de água não influenciou os resultados de condutividade elétrica. Nos lotes 2 e 3 , as sementes com teor de 110 e $130 \mathrm{~g}$ de água/kg, embora não diferindo entre si, apresentaram menor liberação de exsudatos iônicos em relação às sementes com $90 \mathrm{~g}$ de água $/ \mathrm{kg}$, concordando com TAO (1978) e LOEFFLER et al. (1988). Além disso, para TAO (1978), sementes de soja com teor de água de 13, 15 e 19,5\% apresentaram valores semelhantes de condutividade elétrica. Resultados semelhantes foram constatados por LOEFFLER et al. (1988), pois pequenas diferenças ocorreram quando os teores de água permaneceram entre 11 e $18 \%$. 
Tabela 18. Condutividade elétrica: valores médios $(\mu \mathrm{mhos} / \mathrm{cm} / \mathrm{g})$ obtidos para os três lotes de sementes de soja do cultivar IAC-15, com teores de água ajustados, e coeficiente de variação.

\begin{tabular}{ccccr}
\hline & \multicolumn{3}{c}{ Teores de água $(\mathrm{g} / \mathrm{kg}$ de sementes) } & \\
\cline { 2 - 4 } Lotes & 90 & 110 & 130 & Médias \\
\hline 1 & $70.2 \mathrm{Aa}$ & $64.2 \mathrm{Aa}$ & $59.6 \mathrm{Aa}$ & 64.6 \\
2 & $107.8 \mathrm{Bb}$ & $80.9 \mathrm{Ab}$ & $73.1 \mathrm{Ab}$ & 87.2 \\
3 & $116.9 \mathrm{Bb}$ & $94.3 \mathrm{Ac}$ & $93.2 \mathrm{Ac}$ & 101.5 \\
\hline Médias & 98.3 & 79.8 & 75.3 & \\
\hline C.V.(\%) & 7.2 & & & \\
\hline
\end{tabular}

Letras minúsculas: comparações entre médias dentro de cada coluna.

Letras maiusculas: comparações entre médias dentro de cada linha.

O teste de envelhecimento acelerado (Tabela 19) revelou a superioridade do lote 1 em relação aos lotes 2 e 3 , à semelhança do observado no teste de condutividade elétrica (Tabela 18). Nos lotes $\mathrm{I}$ e 2, as sementes com $90 \mathrm{~g}$ de água $/ \mathrm{kg}$ sofreram efeitos menos intensos do envelhecimento que as mais úmidas, concordando com MARCOS FILHO et al. (1978); MARCOS FILHO \& VINHA (1980) e MARCOS FILHO (1994) que verificaram efeitos mais drásticos do envelhecimento acelerado em sementes mais úmidas. No entanto, para o lote 3 , de pior qualidade, o teor de água não influiu significativamente no resultado desse teste. 
Tabela 19. Envelhecimento acelerado: valores médios (\%) obtidos para os três lotes de sementes de soja do cultivar IAC-15, com teores de água ajustados, e coeficiente de variação.

\begin{tabular}{cllll}
\hline & \multicolumn{3}{c}{ Teores de água (g/kg de sementes) } & \\
\cline { 2 - 5 } Lotes & 90 & 110 & 130 & Médias \\
\hline 1 & $88 \mathrm{Aa}$ & $80 \mathrm{Ba}$ & $76 \mathrm{Ba}$ & 81 \\
2 & $76 \mathrm{Ab}$ & $68 \mathrm{Bb}$ & $66 \mathrm{Bb}$ & 70 \\
3 & $60 \mathrm{Ac}$ & $62 \mathrm{Ab}$ & $56 \mathrm{Ac}$ & 59 \\
\hline Médias & 75 & 70 & 66 & \\
\hline C.V.(\%) & 4.2 & & & \\
\hline
\end{tabular}

Letras minúsculas: comparações entre médias dentro de cada coluna.

Letras maíusculas: comparações entre médias dentro de cada linha.

$\mathrm{O}$ exame da Tabela 20 permite verificar que o vigor (TZ 1-3) do lote 1 superou significativamente o do lote 2 , o mesmo ocorrendo em relação ao do lote 3 , à semelhança do observado nos testes de germinação e de primeira contagem (Tabelas $15 \mathrm{e}$ 16). Além disso, esta observação também está de acordo com as apresentadas pelos testes de condutividade elétrica (Tabela 17) e de envelhecimento acelerado (Tabela 18). $\mathrm{Na}$ literatura, diversos estudos tem indicado que o teste de tetrazólio apresenta alta correlação com diferentes métodos de vigor empregados atualmente. COSTA et al. (1988) observaram que o vigor, determinado pelo teste de tetrazólio, apresentou relação com o teste de envelhecimento acelerado. Por outro lado, BARROS (1988) detectou que os testes de tetrazólio e condutividade elétrica são suficientes para a obtenção de informações rápidas, utilizáveis em programas de controle de qualidade. Por esta Tabela, também constatou-se que o teor de água das sementes não interferiu no vigor dos 3 loteš, porém, observou-se pela Tabela 17, que o teor de água interferiu no vigor avaliado pelo teste de condutividade elétrica. Desta forma, devido à natureza do teste de tetrazólio, se durante o pré-condicionamento a embebição for lenta, não deve ser esperado efeito drástico do teor inicial de água. 
Tabela 20. Vigor (TZ 1-3): valores médios (\%) obtidos para os três lotes de sementes de soja do cultivar IAC-15, com teores de água ajustados, e coeficiente de variação.

\begin{tabular}{ccccc}
\hline & \multicolumn{3}{c}{ Teores de água ( $(\mathrm{g} / \mathrm{kg}$ de sementes) } & \\
\cline { 2 - 5 } Lotes & 90 & 110 & 130 & Médias \\
\hline 1 & 92 & 92 & 92 & $92 \mathrm{a}$ \\
2 & 84 & 87 & 89 & $87 \mathrm{~b}$ \\
3 & 82 & 82 & 84 & $83 \mathrm{c}$ \\
\hline Médias & $86 \mathrm{~A}$ & $87 \mathrm{~A}$ & $88 \mathrm{~A}$ & \\
\hline C.V. $(\%)$ & 2.7 & & & \\
\hline
\end{tabular}

Letras minúsculas: comparações entre médias dentro de cada coluna.

Letras maiusculas: comparações entre médias dentro de cada linha.

Nas Tabelas 21 e 22, pode-se constatar que a ocorrência de sintomas de deterioração por "umidade" nas sementes viavéis (TZ 1-5) e nas sementes não viáveis (TZ 6 -8) foi menor no lote 1, de melhor qualidade, em relação aos outros dois lotes, semelhantes entre si.

Pela Tabela 21, também, constatoll-se que os níveis elevados de sementes viáveis com sinais de deterioração por "umiciacie" (TZ 1-5) não resultaram em efeito prejudicial a viabilidade das sementes (Tabela 19), devido à extensão desses danos; considerou-se, portanto, que se os danos tivessem sido suficientemente extensos, as sementes provavelmente não teriam sido classificadas nas categorias 1 a 5 .

Observando-se esses resultados obtidos após o umedecimento artificial, pode-se notar que a viabilidade das sementes, avaliada pelo teste de germinação è tetrazólio, foi superior no lote 1 , embora nem sempre tenha diferido da constatada nos lotes 2 e 3 , seguindo a mesma tendência observada por ocasião das determinações para caracterização dos lotes.

O vigor, estimado pelos testes de primeira contagem e envelhecimento acelerado por ocasião da caracterização dos lotes e pelos testes de primeira contagem e 
tetrazólio por ocasião da caracterização das sementes com diferentes teores de água, foi superior para o lote 1 . Além disso, os testes de condutividade elétrica e envelhecimento acelerado, apesar da interferência do teor de água das sementes, também constataram a tendência de superioridade do lote 1 nesta avaliação após o umedecimento artificial das sementes.

Portanto, dentre estes testes, o de primeira contagem foi o que melhor distinguiu os níveis de vigor dos lotes utilizados, por ocasião da caracterização dos lotes e da caracterização das sementes dos três lotes após umedecimento artificial. No entanto, este teste tem recebido críticas de diversos pesquisadores, no sentido de que o parâmetro em que se baseia, ou seja, de que a velocidade de germinação pode ser afetada por variações de temperatura e umidade do substrato, além de que este teste apresenta baixa sensibilidade, pois muitas vezes não distingue pequenas diferenças de vigor entre os lotes (AOSA, 1983).

Tabela 21. Deterioração por "umidade" (TZ 1-5): valores médios (\%) obtidos para os três lotes de sementes de soja do cultivar IAC-15, com teores de água ajustados, e coeficiente de variação.

\begin{tabular}{cllll}
\hline & \multicolumn{3}{c}{ Teores de água $(\mathrm{g} / \mathrm{kg}$ de sementes $)$} & \\
\cline { 2 - 4 } Lotes & 90 & 110 & 130 & Médias \\
\hline 1 & 70 & 68 & 66 & $68 \mathrm{a}$ \\
2 & 73 & 72 & 71 & $72 \mathrm{~b}$ \\
3 & 74 & 72 & 72 & $73 \mathrm{~b}$ \\
\hline Médias & $72 \mathrm{~A}$ & $71 \mathrm{~A}$ & $70 \mathrm{~A}$ & \\
\hline C.V.(\%) & 2.2 & & & \\
\hline
\end{tabular}

Letras minúsculas: comparações entre médias dentro de cada coluna.

Letras maíusculas: comparações entre médias dentro de cada linha. 
As sementes dos três lotes com maiores teores de água $(110$ e $130 \mathrm{~g} / \mathrm{kg})$ apresentaram melhor desempenho quanto à porcentagem e velocidade de germinação porém, sofreram efeitos mais intensos do envelhecimento acelerado que as mais secas, por ocasião da avaliação após o umedecimento artificial. No entanto, o teor de água das sementes dos três lotes não interferiu na viabilidade, no vigor e na determinação dos sintomas de deterioração, nesta etapa, pelo teste de tetrazólio.

Tabela 22. Deterioração por "umidade" (TZ 6-8): valores médios (\%) obtidos para os três lotes de sementes de soja do cultivar IAC-15, com teores de água ajustados, e coeficiente de variação.

\begin{tabular}{clllc}
\hline & \multicolumn{3}{c}{ Teores de água $(\mathrm{g} / \mathrm{kg}$ de sementes) } & \\
\cline { 2 - 5 } Lotes & 90 & 110 & 130 & Médias \\
\hline 1 & 1.0 & 0.0 & 0.0 & $0.0 \mathrm{a}$ \\
2 & 2.0 & 2.0 & 2.0 & $2.0 \mathrm{~b}$ \\
3 & 5.0 & 4.0 & 3.0 & $4.0 \mathrm{~b}$ \\
\hline Médias & $3.0 \mathrm{~A}$ & $2.0 \mathrm{~A}$ & $2.0 \mathrm{~A}$ & \\
\hline C.V. $(\%)$ & 31.1 & & & \\
\hline
\end{tabular}

Letras minúsculas: comparações entre médias dentro de cada coluna.

Letras maíusculas: comparações entre médias dentro de cada linha.

4.3. Avaliação da absorção de água, sob diferentes potenciais hídricos, em períodos variáveis.

Este estudo, teve por objetivo avaliar, para os três lotes, o processo de absorção de água de sementes, com 90,110 e $130 \mathrm{~g}$ de água $/ \mathrm{kg}$, sob potenciais hídricos do substrato de $-0,04 ;-0,10 ;-0,20$ e $-0,40 \mathrm{MPa}$, através das marchas de absorção e da avaliação da emissão de raiz primária, das sementes intumescidas e dos danos por embebição. 


\subsubsection{Marcha de absorção de água}

Nas Figuras 2 a 8 estão apresentados os resultados obtidos, para quantificar a absorção de água de sementes dos três lotes, com 90,110 e $130 \mathrm{~g}$ de água/kg de sementes úmidas, sob potenciais do substrato de $-0,04 ;-0,10 ;-0,20$ e $-0,40$ MPa.

Examinando-se as Figuras 2 a 8 , em conjunto, observou-se que, as sementes dos três lotes, principalmente, sob o potencial hídrico de $-0,04 \mathrm{MPa}$, absorveram água de maneira semelhante ao padrão trifásico apresentado por LABOURIAU (1983) e por BEWLEY \& BLACK (1985). Assim, as sementes absorveram água mais rapidamente nas primeiras 12 horas, atingindo teores próximos a $400 \mathrm{~g}$ de água $/ \mathrm{kg}$, vindo a absorver mais lentamente durante uma fase intermediária $\mathrm{e}$ tornaram a elevar a velocidade de absorção, atingindo teor de água de cerca de $500 \mathrm{~g} / \mathrm{kg}$, ou seja, de aproximadamente $50 \%$ do seu peso úmido inicial, coincidindo com o aumento, na população, da proporção de sementes que emitiram raiz primária.

Em relação ao teor de água, observou-se que, para os três lotes e para os quatro potenciais hidricos estudados, as senentes com $90 \mathrm{~g}$ de água $/ \mathrm{kg}$ de sementes úmidas tenderam a embeber mais rapidamerte nas primeiras horas, provavelmente, em função do gradiente de potencial hídrico existente entre essas sementes e o substrato. concordando com BEWLEY \& BLACK (1985), que sugeriram que a absorção de água das sementes com menor menor o teor inicial de água ocorre com grande velocidade e depende do gradiente de potencial hídrico. Sendo assim, essa maior velocidade de embebição das sementes com $90 \mathrm{~g}$ de água/kg pode indicar uma maior probabilidade dessas sementes estarem mais sujeitas a danos por embebição. Em outros trabalhos, a maior velocidade de embebição, também foi verificada quando as sementes apresentaramse com menor teor de água (OBENDORF \& HOBBS, 1970; HOBBS \& OBENDORF, 1972; TAO, 1978; AHSWORTH \& ODENDORF, 1980; LOEFFLER et al., 1988).

Pelas Figuras 2 a 8. também, pode-se constatar que com o decorrer do processo de absorção de água, para todos os potenciais hídricos e lotes estudados, a 
velocidade de absorção de água das sementes, com $90 \mathrm{~g}$ de água $/ \mathrm{kg}$, foi semelhante à das sementes que apresentavam-se com teor de 110 e $130 \mathrm{~g}$ de água $/ \mathrm{kg}$, ou seja, com o decorrer do processo, a velocidade de absorção das sementes mais secas tendeu a aproximar-se da velocidade de absorção das sementes mais úmidas.

Durante o processo de absorção de água, com o aumento do teor de água das sementes, provavelmente, foi ocorrendo a reorganização da membrana celular, concordando com BEWLEY \& BLACK (1985). Além disso, para LUZZATTI \& HUDSON (1962), teores superiores a $167 \mathrm{~g}$ de água/kg de sementes úmidas permitem a retomada natural da configuração mais estável das membranas.

Para todos os teores de água e lotes estudados, à medida em que foi reduzido o potencial hídrico inicial do substrato, houve diminuição da velocidade de absorção de água (g de água/hora) das sementes, assim como, também foi constatada diminuição dos teores de água atingidos pelas sementes, de tal modo que as sementes atingiram teores próximos a $500 \mathrm{~g}$ de água $/ \mathrm{kg}$ sob potencial de $-0,04 \mathrm{MPa}$, após 36 horas de embebição e, para os demais potenciais de $-0,10 ;-0,20$ e - $-0,40 \mathrm{MPa}$, atingiram os mesmos teores após 42, 48 e 66 horas de embebição. Isto significa que devido a uma diminuição da velocidade de absorção de água, as sementes sob menores potenciais hídricos demoraram mais tempo para atingirem um determinado teor de água. Para SILVA (1989), a elevação do potencial hídrico acarreta acréscimos do teor de água, porém, a velocidade de absorção uão obedece exatamente a mesma tendência, pois esta está relacionada à fase de hidratação predominante na população no instante de sua avaliação e, consequentemente, ao potencial hídrico desenvolvido por seus indivíduos, de tal forma que as sementes reduzem a absorção de água tão logo sejam emitidas as suas estruturas embrionárias, o que seguramente acontece mais rapidamente pelos individuos mantidos em contato com os potenciais hídricos mais elevados.

Com relação a qualidade fisiológica, as sementes do lote 3 , de qualidade fisiológica inferior aos demais lotes, nas primeiras horas do processo de absorção de água, embeberam mais rapidamente que as sementes dos lotes 1 e 2, para todos os teores de água e potenciais hídricos estudados. 
Neste trabalho, também, pode-se constatar que, no final do processo de embebição, a velocidade de absorção das sementes de pior qualidade fisiológica, do lote 3 , tendeu a aproximar-se da velocidade de embebição das sementes de melhor qualidade. Para VIEIRA et al. (1982) e ROCHA et al. (1984), as sementes de pior qualidade embebem mais rapidamente, ao passo que WOODSTOCK (1988) relatou que as opiniões referentes à associação entre a qualidade fisiológica e a velocidade de absorção de água pelas sementes não são unânimes, pois é dificil individualizar o efeito de permeabilidade do sistema de membranas celulares que frequentemente interage com outros fatores. 

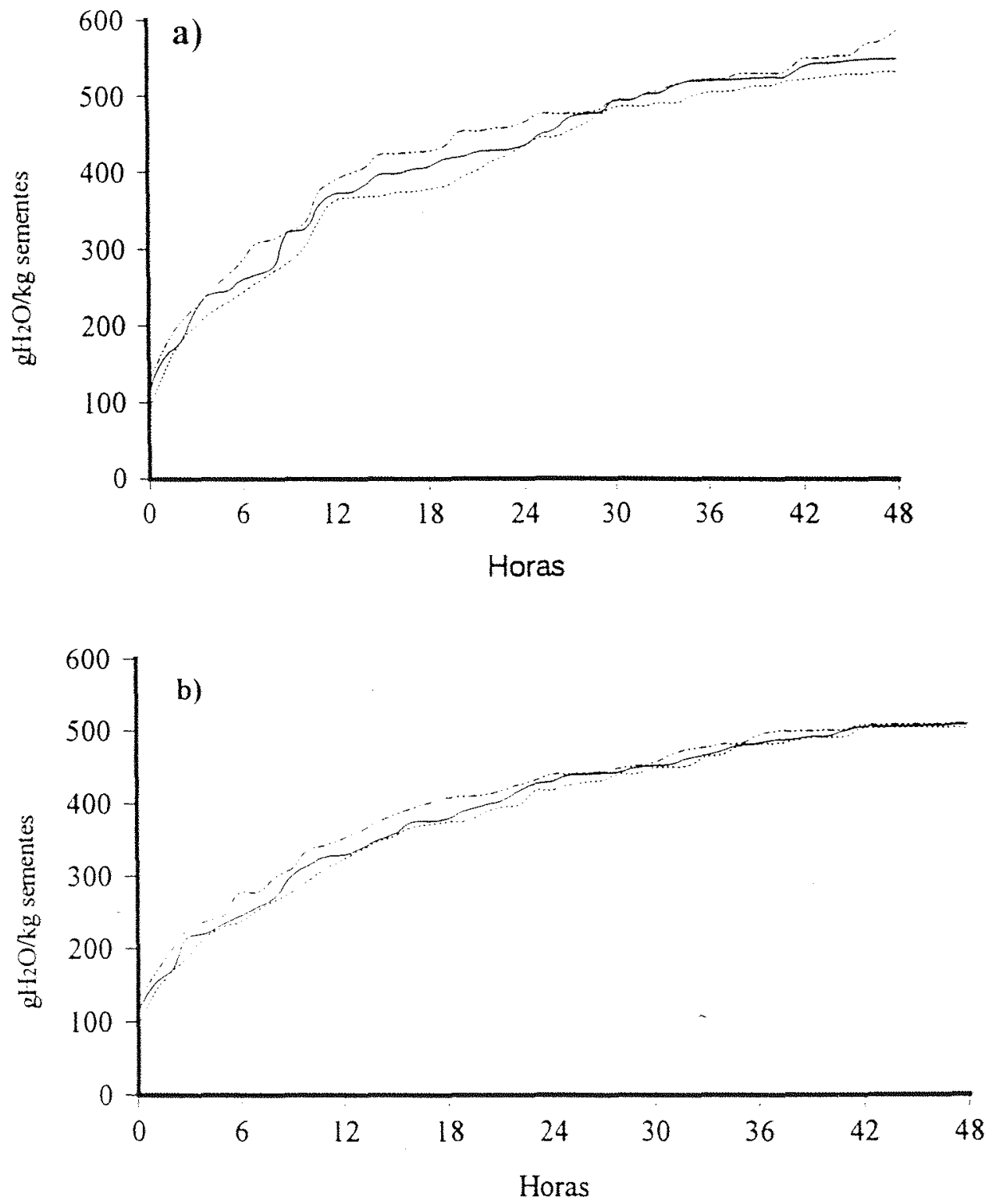

Umidade inicial de $90 \mathrm{~g}$ de água $/ \mathrm{kg}$ de sementes - Umidade inicial de $110 \mathrm{~g}$ de água/kg de sementes -..-Umidade inicial de $130 \mathrm{~g}$ de água/kg de sementes

Figura 2. Marcha de absorção de água, sob tensão de $-0,04$ (a) e $-0,10$ (b) MPa, de sementes do Lote 1 com diferentes teores de água. 

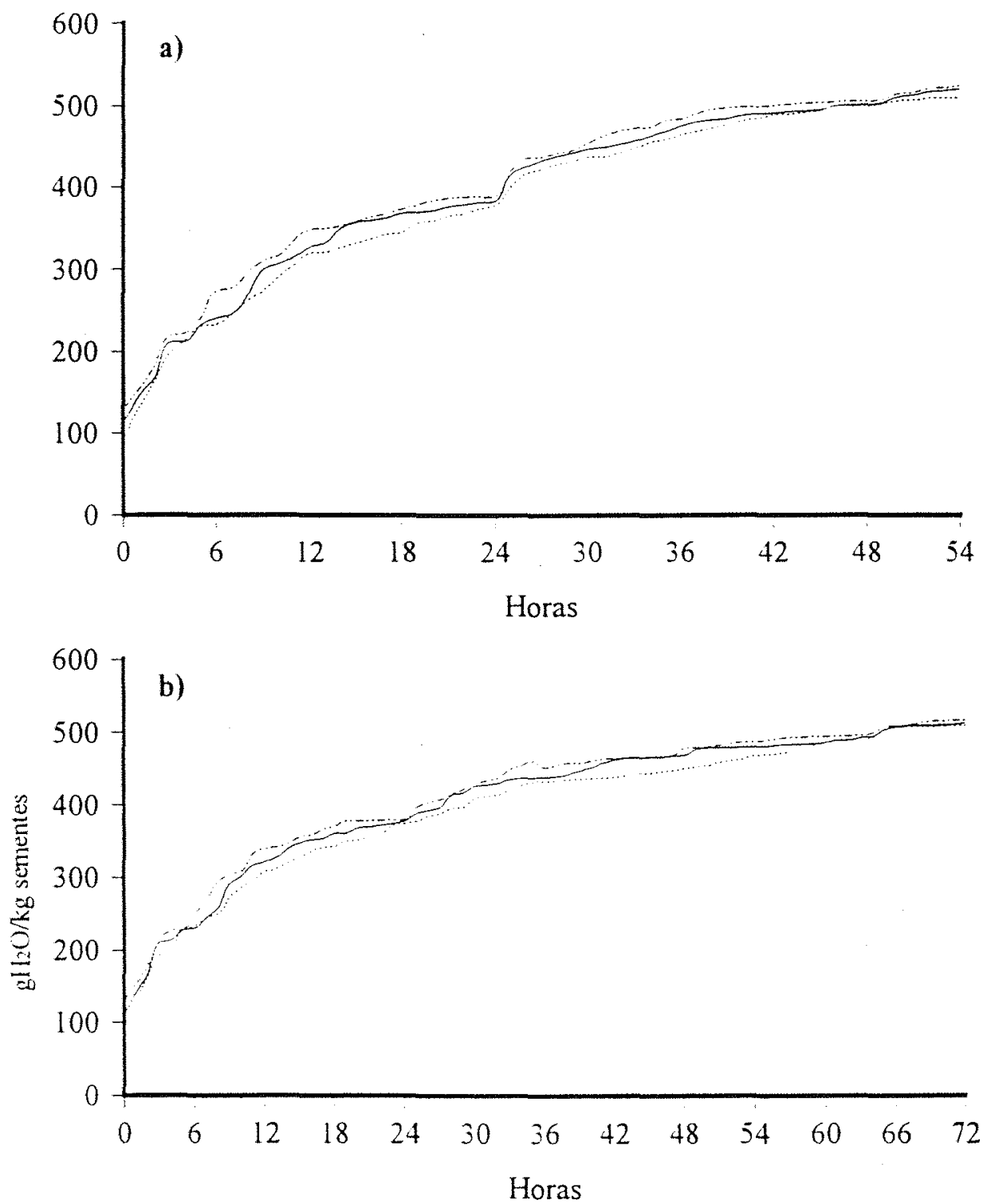

.... Umidade inicial de $90 \mathrm{~g}$ de água $/ \mathrm{kg}$ de sementes -Umidade inicial de $110 \mathrm{~g}$ de água $/ \mathrm{kg}$ de sementes -... Umidade inicial de $130 \mathrm{~g}$ de água $\mathrm{kg}$ de sementes

Figura 3. Marcha de absorção de água. sob tensão de $-0,20$ (a) e $-0,40$ (b) $\mathrm{MPa}$, de sementes do Lote 1 com diferentes teores de água. 

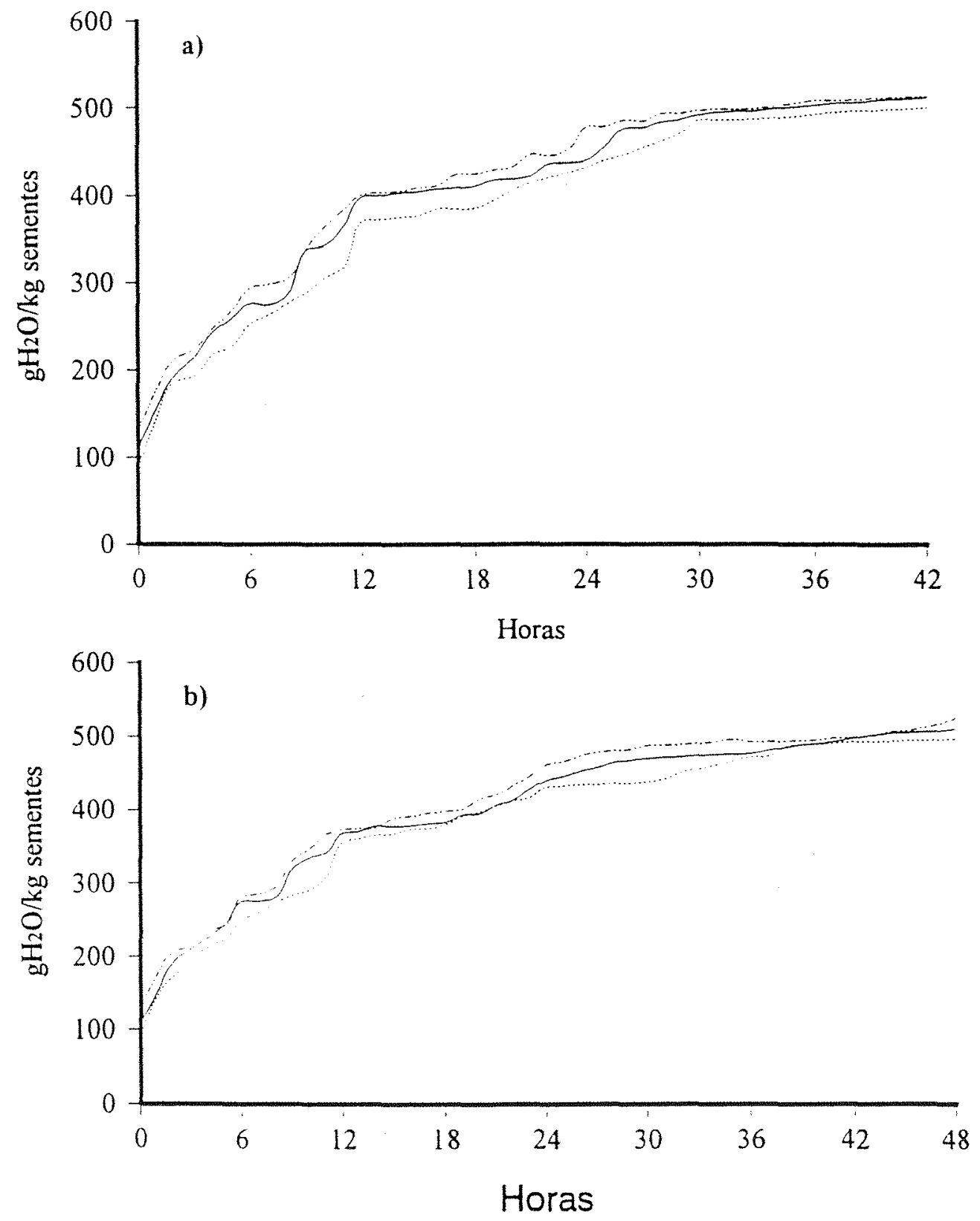

Umidade inicial de $90 \mathrm{~g}$ de água $/ \mathrm{kg}$ de sementes

- Umidade inicial de $110 \mathrm{~g}$ de água $/ \mathrm{kg}$ de sementes

-... Umidade inicial de $130 \mathrm{~g}$ de água $\mathrm{kg}$ de sementes

Figura 4. Marcha de absorção de água, sob tensão de $-0,04$ (a) e $-0,10$ (b) $\mathrm{MPa}$, de sementes do Lote 2 com diferentes teores de água. 

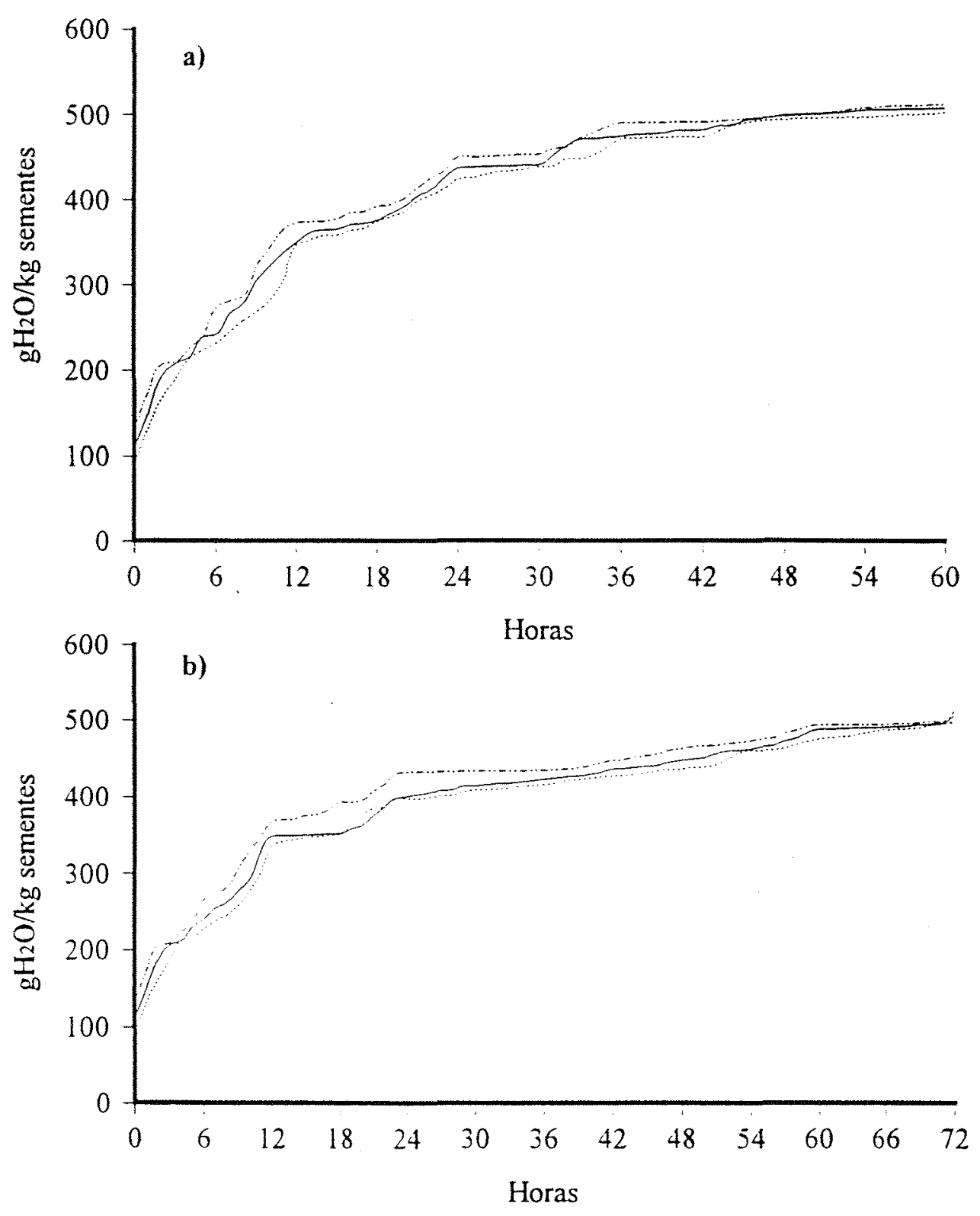

... Umidade inicial de $90 \mathrm{~g}$ de água $\mathrm{kg}$ de sementes

- Umidade inicial de $110 \mathrm{~g}$ de água $/ \mathrm{kg}$ de sementes

-..- Umidade inicial de $130 \mathrm{~g}$ de água $/ \mathrm{kg}$ de sementes

Figura 5. Marcha de absorção de água. sob tensão de $-0,20$ (a) e $-0,40$ (b) MPa, de sementes do Lote 2 com diferentes teores de água. 

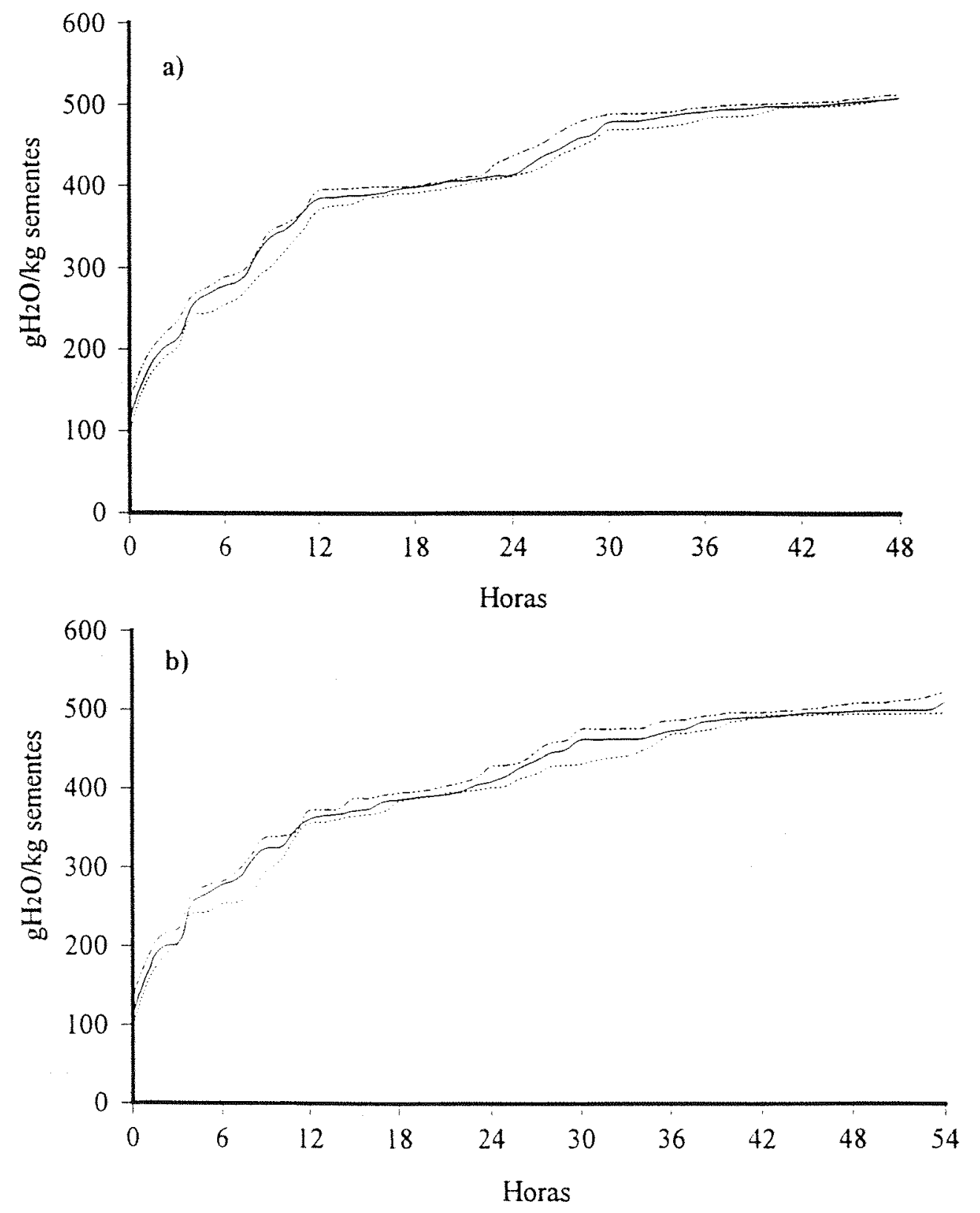

Figura 6. Marcha de absorção de água, sob tensão de $-0,04$ (a) e $-0,10$ (b) MPa, de sementes do Lote 3 com diferentes teores de água. 

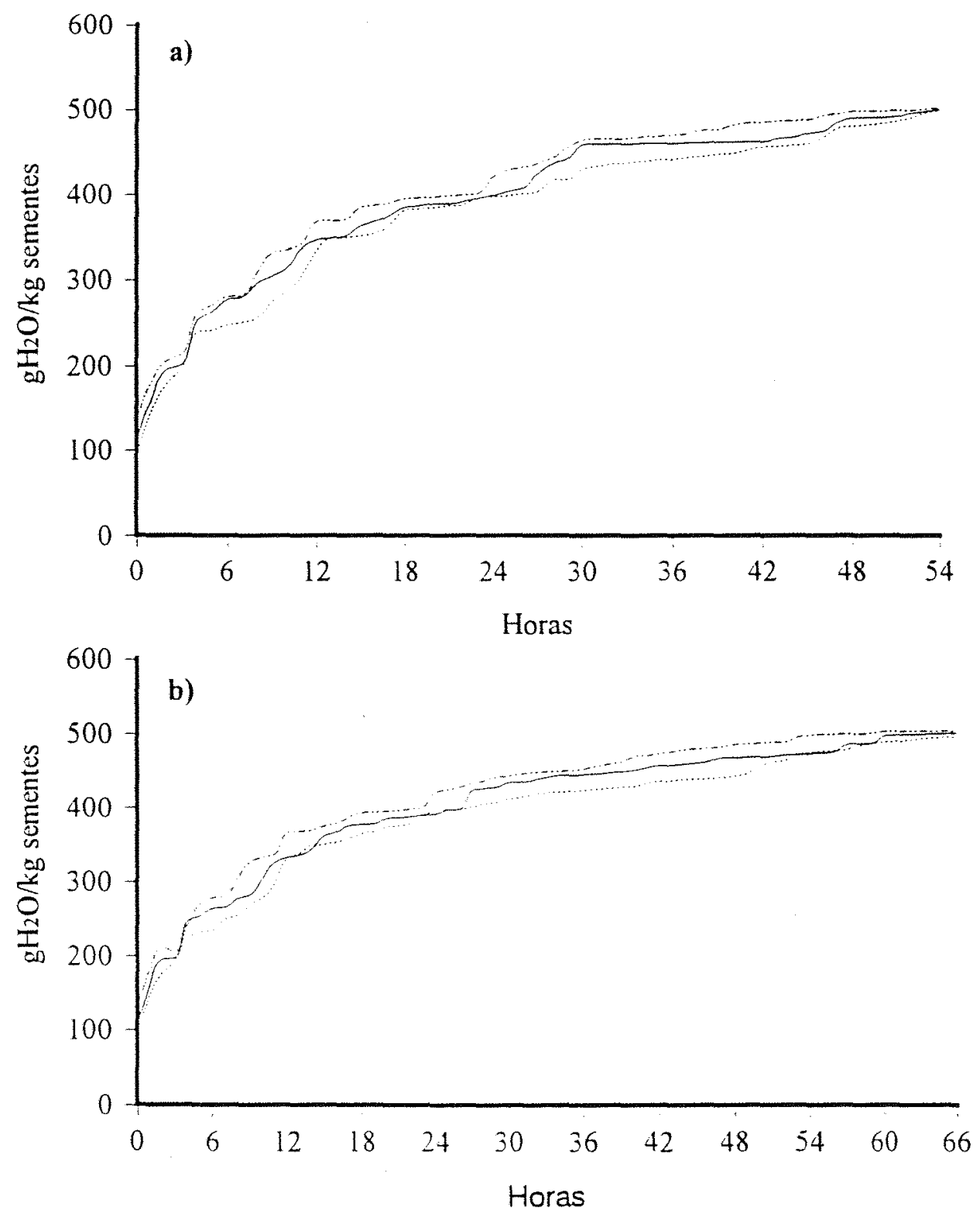

Figura 7. Marcha de absorção de água. sob tensão de -0.20 (a) e $-0,40$ (b) $\mathrm{MPa}$. de sementes do Lote 3 com diferentes teores de água. 


\subsubsection{Emissão de raiz primária}

As porcentagens de sementes dos três lotes, com 90, 110 e $130 \mathrm{~g}$ de água/kg de sementes úmidas, que emitiram raiz primária, sob potenciais hídricos do substrato de $-0,04 ;-0,10 ;-0,20$ e $-0,40 \mathrm{MPa}$, estão apresentadas nas Figuras 8 a 13.

Considerando-se a emissão da raiz primária como o primeiro sinal visível da germinação, a confrontação das marchas de absorção de água das sementes, apresentadas nas Figuras 2 a 7, sugere que, para todos os lotes, teores de água e potenciais hídricos estudados, os teores mínimos de água próximos a $500 \mathrm{~g} / \mathrm{kg}$ de sementes úmidas, ou seja, na proporção de $50 \%$ do peso inicial das sementes, foram suficientes para o início da emissão da raiz primária, concordando com HUNTER \& ERICKSON (1952) e McDONALD Jr et al. (1988a), que constataram que o teor mínimo de hidratação das sementes de soja para que haja início da emissão de raiz primária é de 500 a 550 g de água $/ \mathrm{kg}$ de sementes úmidas. Em trabalho de ARMSTRONG \& Mc DONALD Jr. (1992), 14\% das sementes emitiram raiz primária após 21 horas de embebição sob temperatura de $25^{\circ} \mathrm{C}$, quando o teor de água dos cotilédones, assim como o da semente estava próximo de $550 \mathrm{~g} / \mathrm{kg}$ e, o do eixo embrionário, próximo a $650 \mathrm{~g}$ de água/kg.

Examinando-se as Figuras 8 a 13, em conjunto, pode-se constatar que à medida em que foi reduzido o potencial hidrico do substrato, para os 3 teores iniciais de água e para os três lotes estudados, ocorreu uma diminuição da velocidade de absorção de água pelas sementes, concordando com HUNTER \& ERICKSON (1952); PARMAR. \& MOORE (1968); PHILLIPS (1968); LABOURIAU (1983); CARVALHO \& NAKAGAWA (1983); BRADFORD (1986) e VERTUCCI (1989); que, de um modo geral, verificaram que os retardamentos na absorção e na emissão de raiz primária mostraram-se interdependentes e diretamente relacionados à disponibilidade hídrica do substrato.

À medida que foi reduzido o potencial hídrico, aumentou-se o período de embebição para que as sementes emitissem a raiz primária. Assim, as sementes apresentaram-se com o teor necessário para a emissão da raiz primária, ou seja, atingiram 
$500 \mathrm{~g}$ de água/kg, sob potencial hídrico de $-0,04 \mathrm{MPa}$, após 36 horas de embebição e, para as demais tensões de $-0,10 ;-0,20$ e $-0,40 \mathrm{MPa}$, atingiram o mesmo teor de água após 42, 48 e 66 horas de embebição, conforme já comentado anteriormente (Figuras 2 a 7).

Para todos os teores de água e potenciais hídricos estudados, considerando o mesmo período de embebição que permite atingir o teor de água mínimo para a emissão da raiz primária, observou-se que a porcentagem de sementes do lote 1 superou a do lote 2 , que por sua vez, superou a do lote 3 . Desta forma, nas sementes de pior qualidade fisiológica, dos lotes 2 e 3 , os mecanismos de reparo, provavelmente estavam ausentes ou foram ineficientes, ou ainda, as membranas estavam tão profundamentte danificadas, que o reparo foi impossível, concordando com as informações apresentadas por BEWLEY \& BLACK (1985).

Pelas Figuras 8 a 13, também, pode-se constatar que as sementes dos três lotes, com 110 e $130 \mathrm{~g}$ de água $/ \mathrm{kg}$ de sementes úmidas, emitiram raiz primária mais rapidamente que as sementes com $90 \mathrm{~g}$ de água $/ \mathrm{kg}$, sob situações de diferentes potenciais hídricos do substrato. No entanto, essa diferença nos valores obtidos tendeu a ser reduzida com a diminuição do potencial hídrico, de tal forma que a maior rapidez na emissão da raiz primária com o aumento do teor de água das sementes foi atenuada sob a influência de baixa disponibilidade hídrica do substrato. 

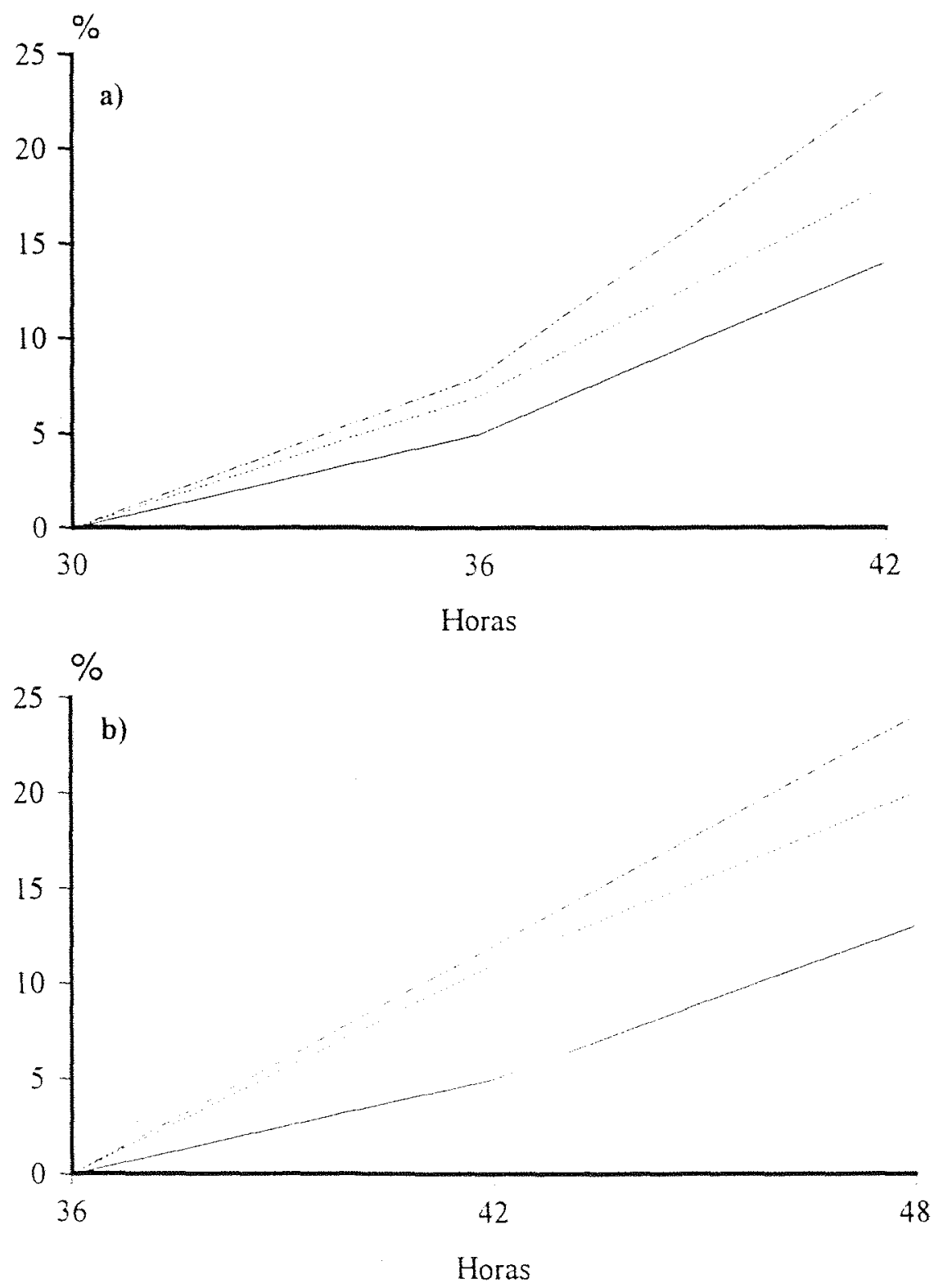

Figura 8. Porcentagem de sementes do Lote 1 , com teores de água distintos, que emitiram raiz primária sob a influência de períodos de embebição e potenciais hídricos: a) -0,04 e b) -0.10 MPa. 


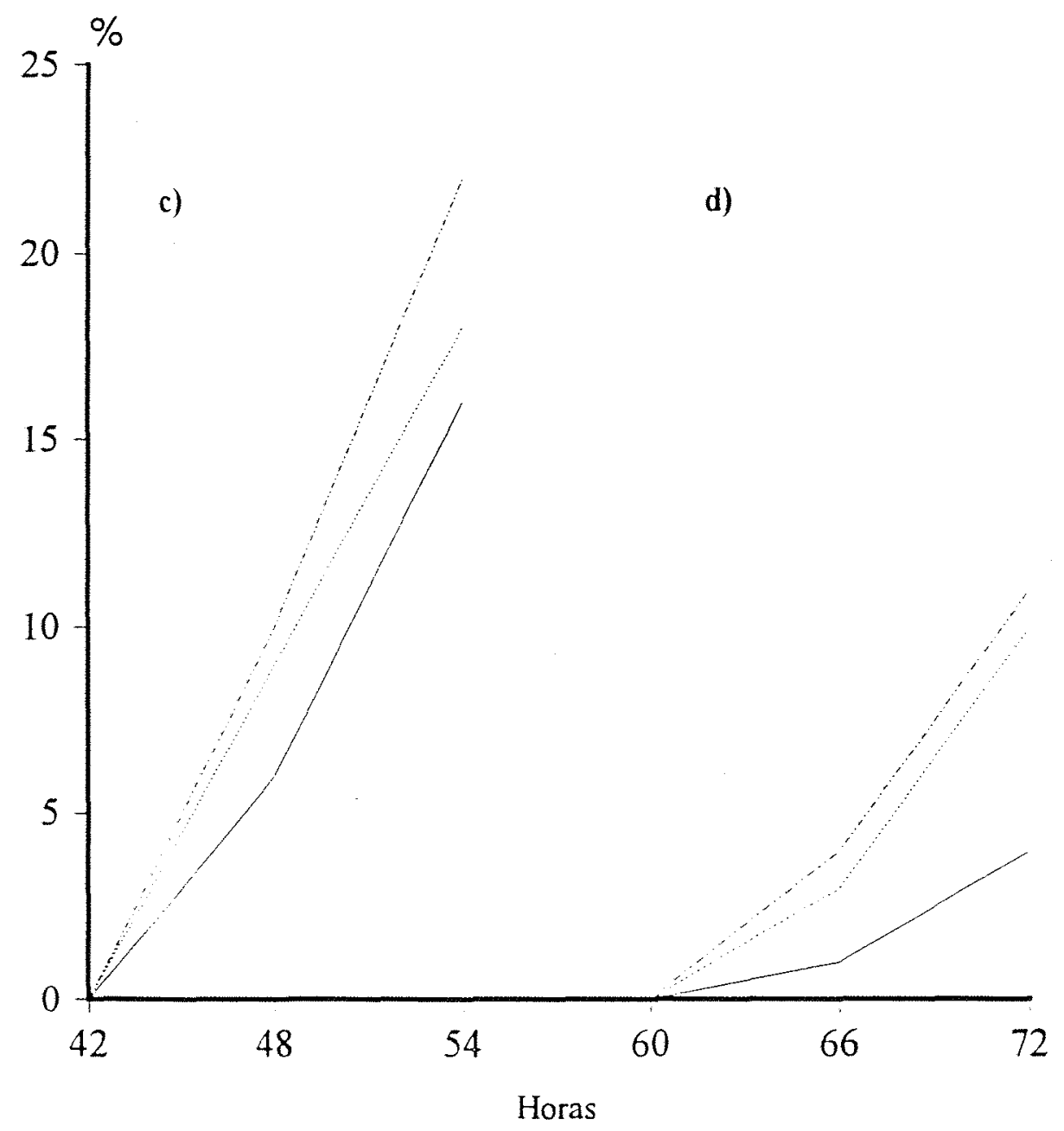

- Umidade inicial de $90 \mathrm{~g}$ de água $/ \mathrm{kg}$ de sementes .. Umidade inicial de $110 \mathrm{~g}$ de água $/ \mathrm{kg}$ de sementes -... Umidade inicial de $130 \mathrm{~g}$ de água $/ \mathrm{kg}$ de sementes

Figura 9. Porcentagem de sementes do Lote 1, com teores de água distintos, que emitiram raiz primária sob a influência de periodos de embebição e potenciais hidricos: c) -0.20 e d) $-0,40 \mathrm{MPa}$. 


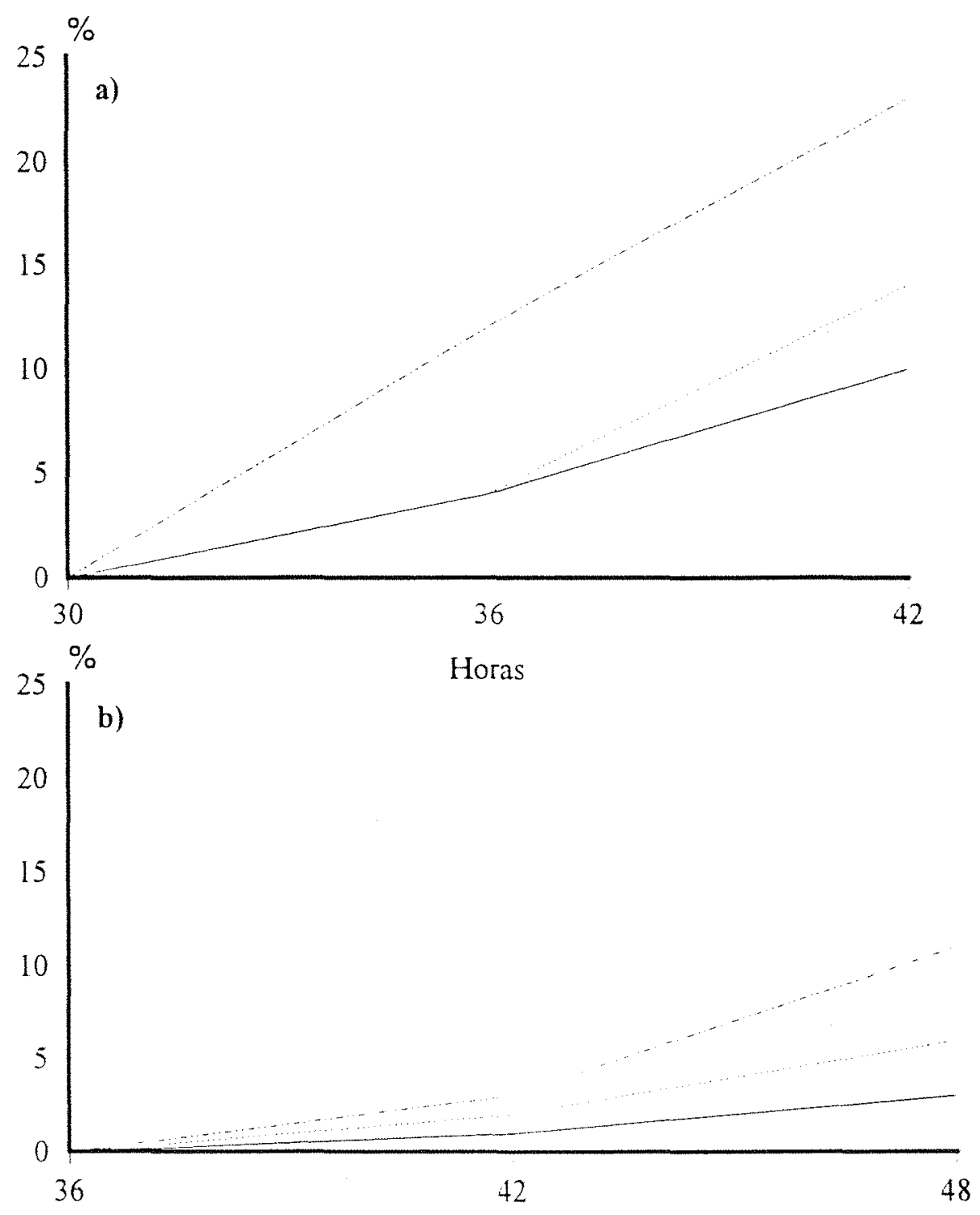

Horas

Figura 10. Porcentagem de sementes do Lote 2, com teores de água distintos, que emitiram raiz primária sob a influència de periodos de embebição e potenciais hídricos: a) -0.04 e b) $-0.10 \mathrm{MPa}$. 


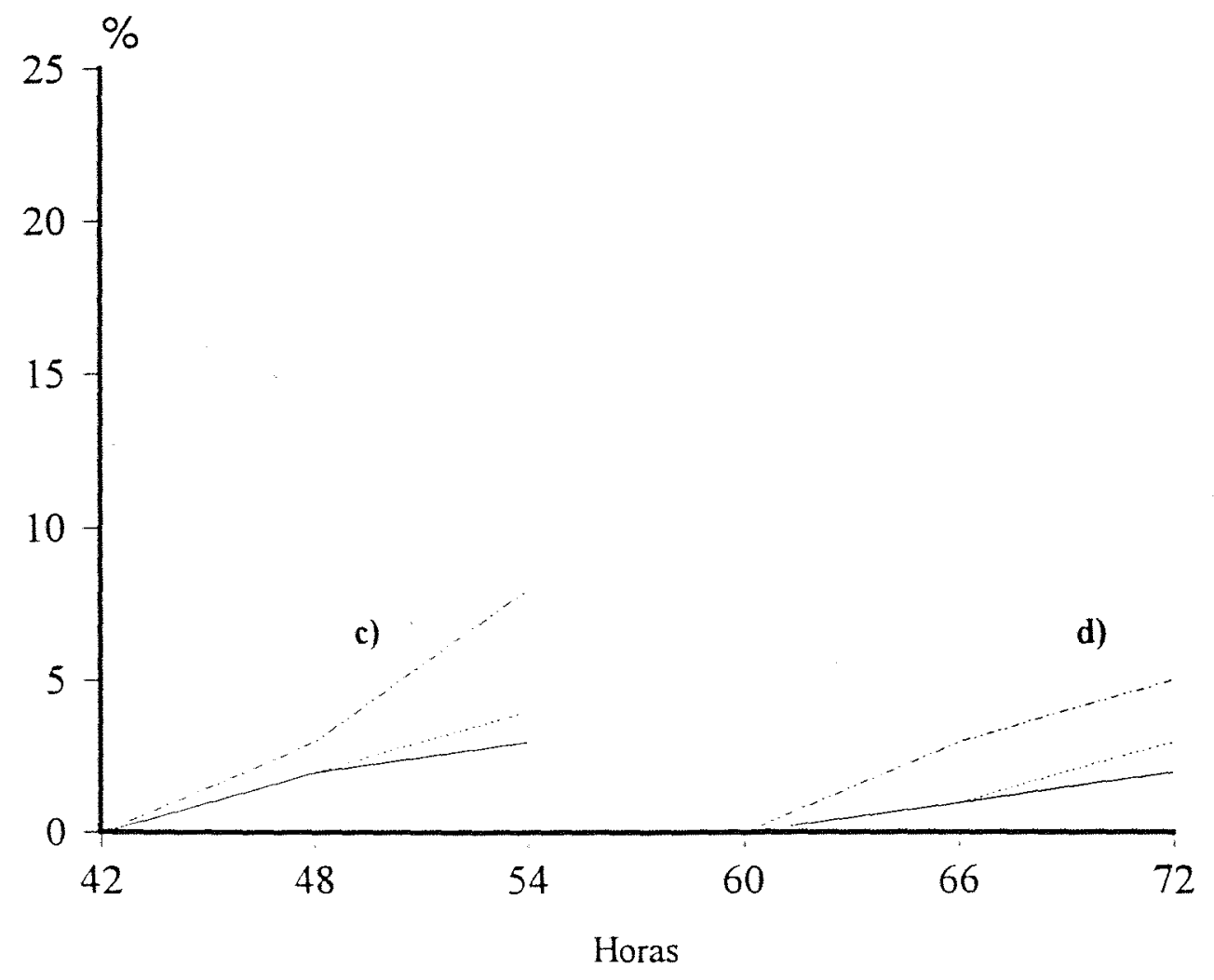

- Umidade inicial de $90 \mathrm{~g}$ de água/ $\mathrm{kg}$ de sementes

...... Umidade inicial de $110 \mathrm{~g}$ de água/ $\mathrm{kg}$ de sementes

-... Umidade inicial de $130 \mathrm{~g}$ de água/kg de sementes

Figura 11. Porcentagem de sementes do Lote 2, com teores de água distintos, que emitiram raiz primária sob a influência de periodos de embebição e potenciais hídricos: c) $-0,20$ e d) $-0,40 \mathrm{MPa}$. 


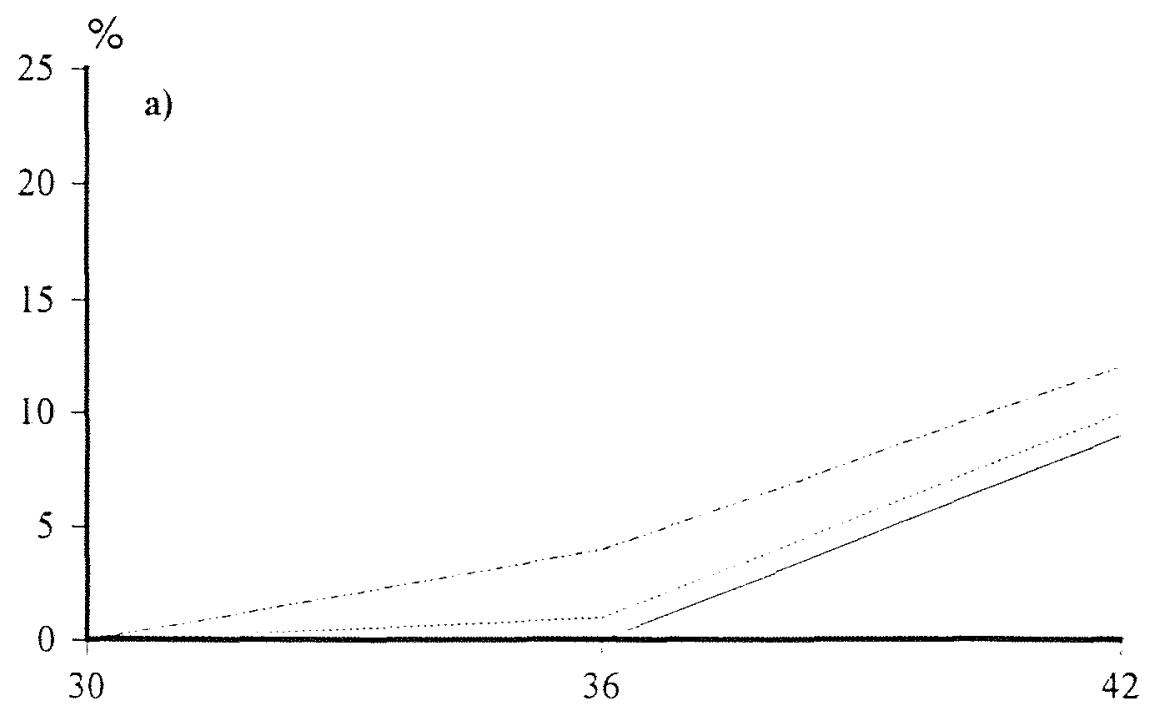

Horas

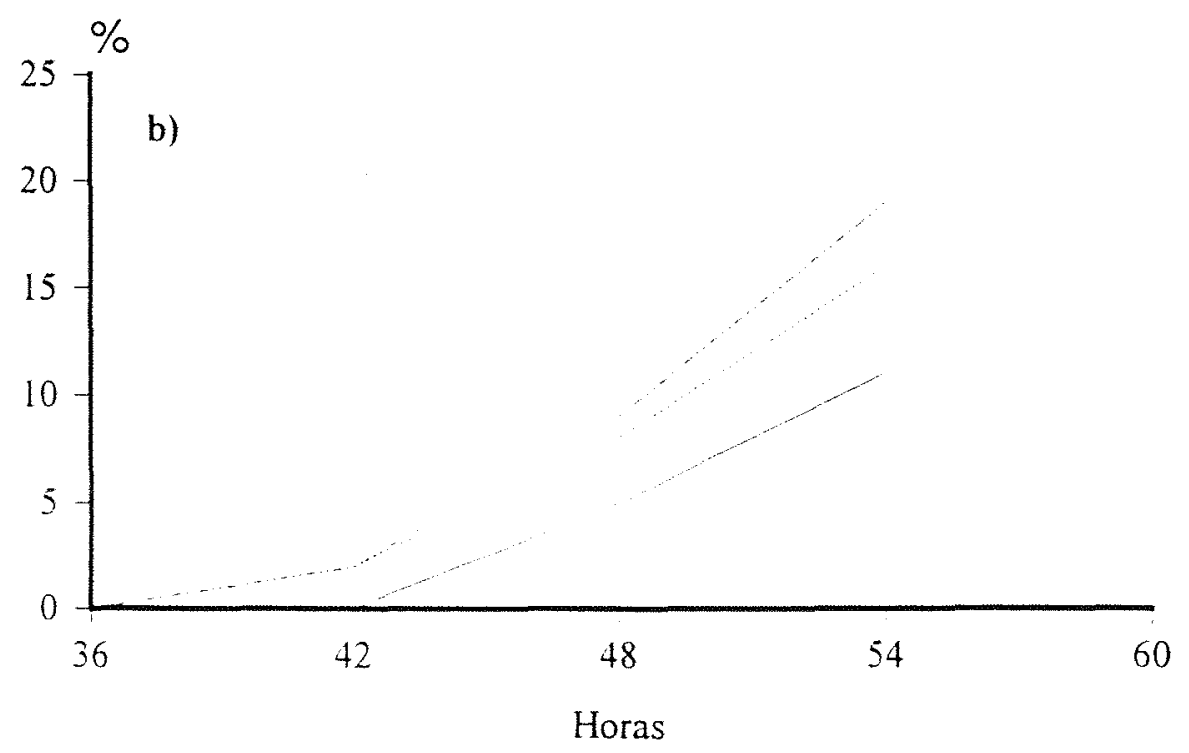

- Umidade inicial de $90 \mathrm{~g}$ de água/kg de sementes Umidade inicial de $110 \mathrm{~g}$ de água $\mathrm{kg}$ de sementes -... Umidade inicial de $130 \mathrm{~g}$ de água $\mathrm{kg}$ de sementes

Figura 12. Porcentagem de sementes do Lote 3 , com teores de água distintos, que emitiram raiz primária sob a influência de períodos de embebição e potenciais hídricos: a) -0.04 e b) $-0.10 \mathrm{MPa}$. 


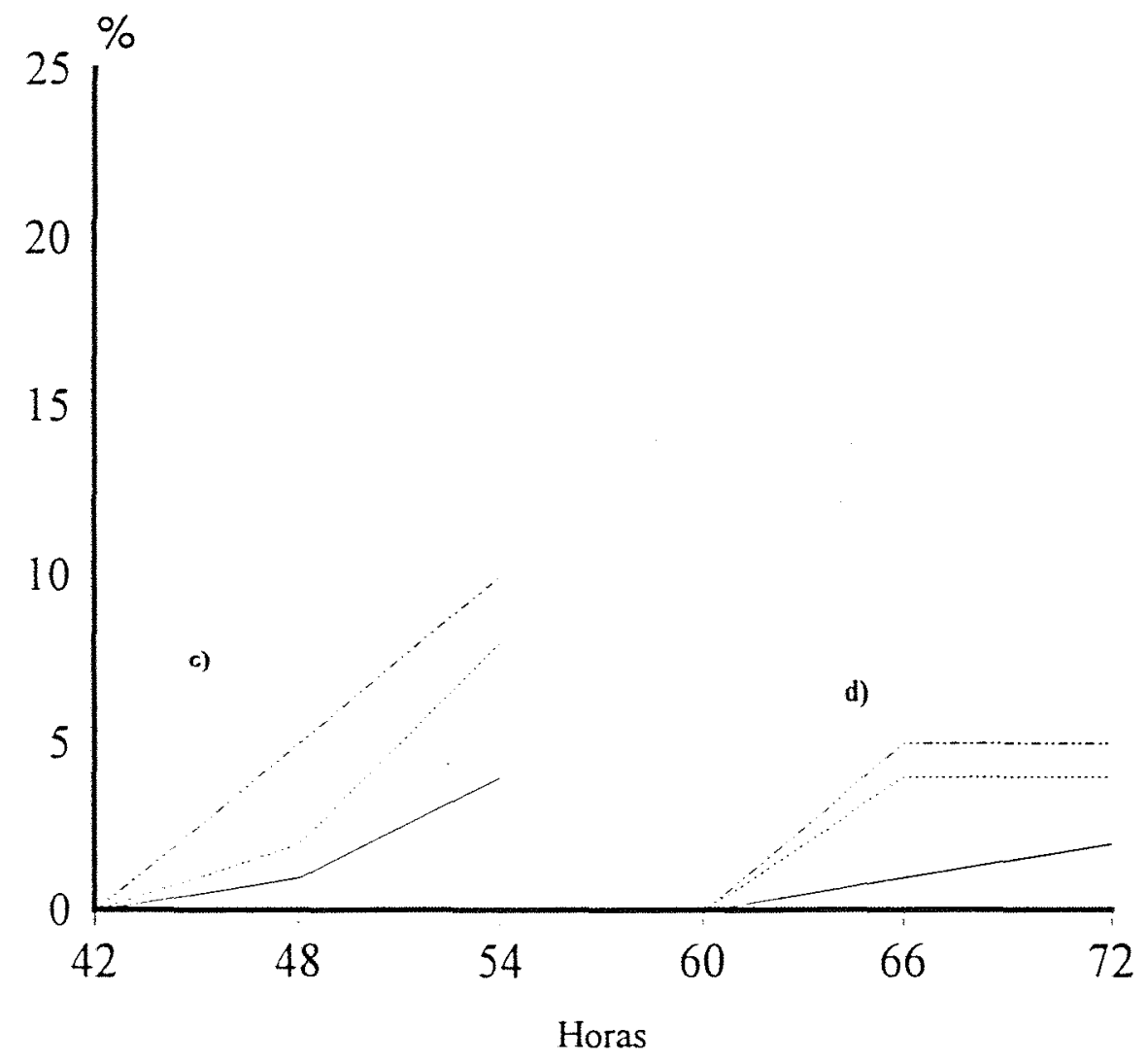

- Umidade inicial de $90 \mathrm{~g}$ de água $\mathrm{kg}$ de sementes Umidade inicial de $110 \mathrm{~g}$ de água/kg de sementes Umidade inicial de $130 \mathrm{~g}$ de água/kg de sementes

Figura 13. Porcentagem de sementes do Lote 3, com teores de água distintos, que emitiram raiz primária sob a influência de períodos de embebição e potenciais hídricos: c) -0,20 e d) -0,40 MPa. 


\subsubsection{Avaliação da proporção de sementes intumescidas}

Examinando-se os valores de $\mathrm{F}$ obtidos nas análises da variància (Tabela 23), verificou-se que ocorreram efeitos significativos, a nível de 5\%, para Tratamentos e para Teores de água sobre a porcentagem de sementes intumescidas do lote 2. Por outro lado, não ocorreram efeitos significativos para a interação Tratamentos x Teores de água sobre a porcentagem de sementes intumescidas dos três lotes.

Tabela 23. Valores de $\mathrm{F}$ obtidos nas análises da variância dos dados referentes à porcentagem de sementes intumescidas após a exposição aos diferentes períodos de absorção de água sob a influência do potencial hídrico de $-0,04$ $\mathrm{MPa}$ (tratamentos), para cada lote.

\begin{tabular}{|c|c|c|}
\hline Lotes & Causas da Variação & $\begin{array}{c}\text { Sementes intumescidas } \\
(\%)\end{array}$ \\
\hline \multirow[t]{3}{*}{1} & Tratamentos $(\mathrm{T})$ & $0.5478^{\mathrm{ns}}$ \\
\hline & Teores de água $(\mathrm{A})$ & $0.1312^{\mathrm{ns}}$ \\
\hline & $\mathrm{T} \times \mathrm{A}$ & $0.0548^{\mathrm{ns}}$ \\
\hline \multirow[t]{3}{*}{2} & Tratamentos $(\mathrm{T})$ & $4.3117^{*}$ \\
\hline & Teores de água $(\mathrm{A})$ & $3.2317^{*}$ \\
\hline & $T \times A$ & $0.4706^{\mathrm{ns}}$ \\
\hline \multirow[t]{3}{*}{3} & Tratamentos $(\mathrm{T})$ & $0.7520^{\mathrm{ns}}$ \\
\hline & Teores de água $(\mathrm{A})$ & 0.7559 ns \\
\hline & $T \times A$ & $1.0505^{\mathrm{ns}}$ \\
\hline
\end{tabular}

significativo ao nivel de $5 \%$ de probabilidade: ${ }^{* *}$ significativo ao nivel de $1 \%$ de probabilidade: ns não significativo 
Para os três teores de água estudados, após a classificação das sementes dos lotes 1 e 3 em peneiras de crivos oblongos de $14 \times 3 / 4$ da polegada, observou-se que, a porcentagem de sementes intumescidas não diferiu após exposição aos diferentes períodos de absorção de água sob a influência do potencial hídrico de $-0,04 \mathrm{MPa}$ (Tabelas 24 e 26). No entanto, após a classificação das sementes do lote 2, constatou-se que a porcentagem de sementes intumescidas foi estável após 4 horas de embebição a 0,04 MPa. Assim, pode-se inferir que seria necessário considerar as mudanças mais acentuadas de espessura, uma vez que a escolha da utilização da peneira 14 × 3/4 não foi adequada, pois as diferenças acusadas por essa peneira em relação a peneira $13 \times 3 / 4$ foram mínimas. Além disso, para o lote 1 , o teor inicial de água não interferiu na porcentagem de sementes intumescidas (Tabela 24) e, para os lotes 2 e 3, o aumento do teor de água proporcionou diminuição da porcentagem de sementes intumescidas (Tabelas 25 e 26).

Os procedimentos adotados para esse estudo, provavelmente, resultaram em danos indesejáveis às sementes com menor teor de água, principalmente às dos lotes 2 e 3 , em consequência de que essas sementes absorveram água muito rapidamente em relação às mais úmidas (110 e $130 \mathrm{~g}$ de água $/ \mathrm{kg}$ de sementes), como também constatado nas Figuras 2 a 7. No entanto, para BEWLEY \& BLACK (1985), em uma determinada amostra submetida à embebição, as sementes que intumescem mais rapidamente são aquelas que, independentemente da sua qualidade fisiológica, também rapidamente iniciam a fase I da embebição e alcançam a fase II.

Em relação à utilização da porcentagem de sementes intumescidas como um possivel teste baseado na velocidade de absorção de água pelas sementes, pode-se inferir que, somente após novos estudos, considerando a avaliação de mudanças mais acentuadas de espessura das sementes, a avaliação da porcentagem de sementes intumescidas possa vir a ser utilizada como um teste que permita a avaliação rápida da viabilidade das sementes de soja. Para tanto, a determinação das porcentagens de retenção em diferentes peneiras durante a embebição, e a comparação desses resultados com os obtidos em outros testes seria um dos procedimentos sugeridos. 
Tabela 24. Sementes intumescidas: valores médios (\%) obtidos para o lote 1 de sementes de soja do cultivar IAC-15, com teores de água ajustados, após exposição à combinação entre períodos de absorção de água e potencial hídrico de $-0,04$ MPa (tratamentos), e coeficiente de variação.

\begin{tabular}{ccccc}
\hline Tratamentos & \multicolumn{3}{c}{ Teores de água (g/kg de sementes) } & \\
\cline { 2 - 4 }$(\mathrm{MPa} / \mathrm{h})$ & 90 & 110 & 130 & Médias \\
\hline$-0,04 / 2$ & 62 & 60 & 62 & $61 \mathrm{a}$ \\
$-0,04 / 4$ & 64 & 63 & 63 & $63 \mathrm{a}$ \\
$-0,04 / 6$ & 64 & 64 & 64 & $64 \mathrm{a}$ \\
$-0,04 / 9$ & 66 & 64 & 68 & $66 \mathrm{a}$ \\
\hline Médias & $64 \mathrm{~A}$ & $63 \mathrm{~A}$ & $64 \mathrm{~A}$ & \\
\hline C.V. $(\%)$ & 10.2 & & \\
\hline
\end{tabular}

Letras minúsculas: comparaçōes entre médias dentro de cada coluna.

Letras maíusculas: comparaçōes entre médias dentro de cada linha.

Tabela 25. Sementes intumescidas: valores médios (\%) obtidos para o lote 2 de sementes de soja do cultivar IAC-15, com teores de água ajustados, após exposição à combinação entre períodos de absorção de água e potencial hídrico de -0,04 MPa (tratamentos), e coeficiente de variação.

\begin{tabular}{ccccc}
\hline Tratamentos & \multicolumn{3}{c}{ Teores de agua $(\mathrm{g} / \mathrm{kg}$ de sementes $)$} & \\
\cline { 2 - 4 }$(\mathrm{MPa} / \mathrm{h})$ & 90 & 110 & 130 & Médias \\
\hline$-0,04 / 2$ & 69 & 58 & 59 & $62 \mathrm{~b}$ \\
$-0,04 / 4$ & 73 & 69 & 64 & $69 \mathrm{ab}$ \\
$-0,04 / 6$ & 73 & 73 & 68 & $71 \mathrm{a}$ \\
$-0,04 / 9$ & 74 & 75 & 70 & $73 \mathrm{a}$ \\
\hline Médias & $72 \mathrm{~A}$ & $69 \mathrm{AB}$ & $65 \mathrm{~B}$ & \\
\hline C.V. $(\%)$ & 8.8 & & \\
\hline
\end{tabular}

Letras minúsculas: comparações entre médias dentro de cada coluna.

Letras maiusculas: comparações entre médias dentro de cada linha. 
Tabela 26. Sementes intumescidas: valores médios (\%) obtidos para o lote 3 de sementes de soja do cultivar IAC-15, com teores de água ajustados, após exposição à combinação entre períodos de absorção de água e potencial hídrico de $-0,04$ MPa (tratamentos), e coeficiente de variação.

\begin{tabular}{|c|c|c|c|c|}
\hline \multirow{2}{*}{$\begin{array}{c}\text { Tratamentos } \\
(\mathrm{MPa} / \mathrm{h})\end{array}$} & \multicolumn{3}{|c|}{ Teores de água ( $\mathrm{g} / \mathrm{kg}$ de sementes) } & \multirow[b]{2}{*}{ Médias } \\
\hline & 90 & 110 & 130 & \\
\hline$-0,04 / 2$ & 77 & 73 & 75 & $75 a$ \\
\hline$-0,04 / 4$ & 81 & 83 & 76 & $80 a$ \\
\hline$-0,04 / 6$ & 84 & 84 & 79 & $82 \mathrm{a}$ \\
\hline$-0,04 / 9$ & 84 & 63 & 83 & $77 \mathrm{a}$ \\
\hline Médias & $82 \mathrm{~A}$ & $76 \mathrm{~A}$ & $78 \mathrm{~A}$ & \\
\hline C.V. $(\%)$ & 13.8 & & & \\
\hline
\end{tabular}

Letras minúsculas: comparações entre médias dentro de cada coluna.

Letras maiusculas: comparações entre médias dentro de cada linha.

\subsubsection{Avaliação dos danos por embebição}

\subsubsection{Liberação de íons}

Examinando-se os resultados das análises da variância, apresentadas nas Tabelas 27 a 29 , pode-se constatar valores de $\mathrm{F}$ significativos para o efeito da interação Períodos de absorção de água $\mathrm{x}$ Teores de água após exposição das sementes do lote 1 aos potenciais hídricos de $-0,10 ;-0,20$ e $-0,40 \mathrm{MPa}$ (Tabela 27) e, após exposição das sementes do lote 2 ao potencial hídrico de $-0,40 \mathrm{MPa}$ (Tabela 28). 
Tabela 27. Valores de $\mathrm{F}$ obtidos nas análises da variância dos dados referentes a liberação de íons para avaliação dos danos por embebição, após exposição à combinação entre determinados períodos de absorção de água e diferentes potenciais hídricos, para o lote 1 .

\begin{tabular}{clc}
\hline Potenciais Hídricos (MPa) & Causas da Variação & Liberação de ions ( $\mu \mathrm{mhos} / \mathrm{cm} / \mathrm{g})$ \\
\hline \multirow{2}{*}{$-0,04$} & Periodos (P) & $14.2261^{* *}$ \\
& Teores de água (A) & $43.2770^{* *}$ \\
& P X A & $1.2750^{\mathrm{ns}}$ \\
$-0,10$ & Periodos (P) & $12.9804^{* *}$ \\
& Teores de água (A) & $56.3030^{* *}$ \\
& PX A & $4.3641^{* *}$ \\
$-0,20$ & Periodos (P) & $15.6579^{* *}$ \\
& Teores de água (A) & $60.2610^{* *}$ \\
& PX A & $3.3757^{* *}$ \\
$-0,40$ & Periodos (P) & $3.6322^{* *}$ \\
& Teores de água (A) & $22.7164^{* *}$ \\
& PX A & $1.9279^{*}$ \\
\hline
\end{tabular}

significativo ao nivel de $5 \%$ de probabilidade. ${ }^{* *}$.nificativo ao nivel de $1 \%$ de probabilidade: ns não significativo 
Tabela 28. Valores de $\mathrm{F}$ obtidos nas análises da variância dos dados referentes a liberação de íons para avaliação dos danos por embebição, após exposição à combinação entre determinados períodos de absorção de água e diferentes potenciais hídricos, para o lote 2 .

\begin{tabular}{clc}
\hline Potenciais Hidricos (MPa) & Causas da Variação & Liberação de íons ( $\mu \mathrm{mhos} / \mathrm{cm} / \mathrm{g})$ \\
\hline \multirow{2}{*}{0,04} & Periodos (P) & $8.5417^{* *}$ \\
& Teores de água (A) & $25.6941^{* *}$ \\
& P X A & $0.8937^{\mathrm{ns}}$ \\
$-0,10$ & Periodos (P) & $14.5851^{* *}$ \\
& Teores de água (A) & $16.2742^{* *}$ \\
& PX A & $1.5481^{\mathrm{ns}}$ \\
$-0,20$ & Periodos (P) & $15.6422^{* *}$ \\
& Teores de água (A) & $2.0099 \mathrm{~ns}$ \\
& P X A & $0.1119 \mathrm{~ns}$ \\
& Periodos (P) & $17.3246^{* *}$ \\
& Teores de água (A) & $16.3914^{* *}$ \\
& PX A & $2.0316^{*}$ \\
\hline
\end{tabular}

* significativo ao nivel de $5 \%$ de probabilidade; ${ }^{* *}$ significativo ao nivel de $1 \%$ de probabilidade; ns não significativo

Também, constatou-se valor de $\mathrm{F}$ altamente significativo para os efeitos de Períodos de absorção de água sobre a liberação de íons após exposição das sementes do lote 1 ao potencial hídrico de -0,04 MPa (Tabela 27); após exposição das sementes do lote 2 aos potenciais hídricos de $-0,04 ;-0,10$ e -0,20 MPa (Tabela 28) e após exposição das sementes do lote 3 aos diferentes potenciais hídricos (Tabelas 29).

Para os efeitos de Teores de água sobre a liberação de íons, verificaram valores de $\mathrm{F}$ significativos após exposição das sementes do lote 1 aos potenciais hídricos de -0,04 MPa (Tabela 27); após à exposição das sementes do lote 2 aos potenciais 
hídricos de -0,04 e -0,10 MPa (Tabela 28) e após exposição das sementes do lote 3 aos potenciais hídricos de $-0,10 ;-0,20$ e $-0,40 \mathrm{MPa}$ (Tabela 29).

Tabela 29. Valores de $\mathrm{F}$ obtidos nas análises da variância dos dados referentes a liberação de íons para avaliação dos danos por embebição, após exposição à combinação entre determinados períodos de absorção de água e diferentes potenciais hídricos, para o lote 3 .

\begin{tabular}{|c|c|c|}
\hline Potenciais Hidricos (MPa) & Causas da Variaçăo & Liberação de íons $(\mu \mathrm{mhos} / \mathrm{cm} / \mathrm{g})$ \\
\hline$-0,04$ & $\begin{array}{l}\text { Periodos (P) } \\
\text { Teores de agua (A) } \\
\text { P X A }\end{array}$ & $\begin{array}{l}5.7177^{* *} \\
2.9216^{\mathrm{ns}} \\
0.1349 \mathrm{~ns}\end{array}$ \\
\hline$-0,10$ & $\begin{array}{l}\text { Periodos (P) } \\
\text { Teores de água (A) } \\
\text { P X A }\end{array}$ & $\begin{array}{c}3.0434^{*} \\
3.2862^{*} \\
0.0898^{\text {ns }}\end{array}$ \\
\hline$-0,20$ & $\begin{array}{l}\text { Periodos (P) } \\
\text { Teores de água (A) } \\
\text { PX A }\end{array}$ & $\begin{array}{l}7.2797^{* *} \\
3.8441^{*} \\
0.2657^{\mathrm{ns}}\end{array}$ \\
\hline-0.40 & $\begin{array}{l}\text { Períodos }(\mathrm{P}) \\
\text { Teores de agua }(\mathrm{A}) \\
\text { PXA }\end{array}$ & $\begin{array}{l}11.9585^{* *} \\
9.6132^{* *} \\
0.2193^{\mathrm{ns}}\end{array}$ \\
\hline
\end{tabular}

* significativo ao nivel de $5 \%$ de probabilidade: ${ }^{* *}$ significativo ao nivel de $1 \%$ de probabilidade: ns não significativo 
Observando as Tabelas 30 a 32, em conjunto, observou-se que para todos os lotes e teores de água, à medida em que foi reduzido o potencial hídrico do substrato, houve uma redução na intensidade de liberação de íons durante as primeiras 24 horas de absorção de água devido, provavelmente, a diminuição da velocidade de absorção de água, como constatado anteriormente pelas Figuras 2 a 7 . Desta forma, provavelmente, as sementes se encontravam em fases diferentes no processo de hidratação.

Sob plena disponibilidade hídrica, a liberação de íons das sementes dos lotes 1 e 2 foi relativamente intensa nas primeiras 6 horas de embebição sob o potencial hídrico de -0,04 $\mathrm{MPa}$, para os três teores de água das sementes estudados. Além disso, as sementes com menor teor inicial de água, $90 \mathrm{~g} / \mathrm{kg}$, apresentaram maior liberação em relação às mais úmidas, concordando com PARRISH \& LEOPOLD (1977) que observaram que a liberação de íons, avaliada pela condutividade elétrica da solução, varia com o teor inicial de água das sementes, sendo que as mais secas, com $35 \mathrm{~g}$ de água $/ \mathrm{kg}$ de sementes úmidas, mostraram maior liberação que as mais úmidas, ou seja, com 78 e $88 \mathrm{~g}$ de água/kg de sementes úmidas.

As sementes com menor teor de água apresentam conformação hexagonal dos fosfolipídios que compõem as membranas, o que permite a perda indiscriminada de substâncias no interior das células (SINGER \& NICHOLSON, 1972); porém, dependendo da velocidade de hidratação, estas membranas se reorganizam durante a embebição (SIMON \& MILLS, 1983). Desta forma, pode-se constatar neste traballo que, com o aumento do teor de água das sementes, houve uma diminuição da liberação de íns devido à possibilidade de reparo celular, ou seja, de ocorrer a restauração das membranas sob condição de hidratação lenta.

As sementes do lote 3, de pior qualidade fisiológica, apresentaram maior liberação de íons nas primeiras 4 horas de embebição sob o potencial hídrico de $-0,04$ $\mathrm{MPa}$, para os três teores de água estudados. No entanto, a liberação de íons pelas sementes com menor teor de água, $90 \mathrm{~g} / \mathrm{kg}$, não diferiu da liberação de íons pelas demais $(110$ e $130 \mathrm{~g} / \mathrm{kg}$ ) sob essa condição de plena disponibilidade hídrica (Tabela 32). Assim, o aumento do teor de água para 110 e $130 \mathrm{~g} / \mathrm{kg}$ não interferiu na liberação de íons das sementes do lote 3 pois, provavelmente, sob plena disponibilidade hídrica, onde a 
velocidade de absorção foi maior, não houve tempo para reparo das membranas que já apresentavam-se danificadas. Para BEWLEY \& BLACK (1985), em sementes mais deterioradas ou não viáveis, os mecanismos de reparo estariam ausentes ou seriam imeficientes, ou ainda, as membranas estariam tão profundamente danificadas, que o reparo seria impossível.

Quando a disponibilidade de água foi menor, ou seja, sob condição de hidratação mais lenta, a liberação de íons das sementes do lote 1, que apresentavam-se com menor teor de água, foi mais intensa nas primeiras horas de embebição, sob potenciais hídricos de $-0,10 ;-0,20$ e $-0,40 \mathrm{MPa}$, e não diferiu das mais úmidas após esses períodos de embebição. Assim, no início do processo de absorção de água, a liberação de íns das sementes secas foi mais intensa e, com o decorrer do processo, a quantidade de exsudatos iônicos das sementes foi se estabilizando, provavelmente, devido à restauração das membranas (Tabela 30). Para BEWLEY \& BLACK (1985), com o decorrer desse processo de absorção de água ocorre a retomada natural da configuração mais estável das membranas ou reparo das membranas por algum mecanismo enzimático ainda não identificado perfeitamente.

Para as sementes do lote 2. quando a disponibilidade hídrica foi menor, a liberação de íons foi mais intensa nas primenas 4 horas de embebição sob potencial hídrico de $-0,10$ e -0,20 $\mathrm{MPa}$, para os trés tenres de água estudados. Além disso, a liberação de íons foi mais intensa nas sementes com menor teor inicial de água $(90 \mathrm{~g} / \mathrm{kg}$ sementes) sob a influência desses mesmos potenciais (Tabela 31 ).

Para as sementes do lote 3. sob condição de baixa disponibilidade hídrica, a liberação de ions foi mais intensa nas primeiras horas de embebição sob potencial hidricos de $-0,10 ;-0,20$ e $-0,40 \mathrm{MPa}$, para os très teores de água estudados. Além disso, a liberaçào de ions foi mais intensa pelas sementes com menor teor de água $(90 \mathrm{~g} / \mathrm{kg}) \mathrm{sob}$ os mesmos potenciais hídricos (Tabela 32 ).

Desta forma. neste trabalho, para o lote 3, sob condição de hidratação mais lenta, sob influência de potenciais hidricos menores, o aumento do teor de água das sementes atenuou a velocidade de absorção de água, possivelmente por permitir uma 
reorganização das membranas em função da menor velocidade de absorção em condição de baixa disponibilidade hídrica (Tabela 32).

Em termos numéricos, quando compararam-se os 3 lotes, observou-se que a liberação de íons foi ligeiramente acentuada no lote 3 (Tabela 32), provavelmente, em função dos danos nos tegumentos dessas sementes, concordando com LOOMIS \& SMITH (1980); WOODSTOCK \& TAO (1981); SCHOETTLE \& LEOPOLD (1984); BRUGGINK et al. (1991) e BEECROFT \& LOTT (1993), segundo os quais a liberação de íons aumenta com a idade e com a presença de danos nos tegumentos das sementes. 
Tabela 30. Liberação de íons: valores médios $(\mu \mathrm{mhos} / \mathrm{cm} / \mathrm{g})$ obtidos para o lote 1 de sementes de soja do cultivar IAC-15, com teores de água ajustados, após exposição à combinação entre períodos de absorção de água e diferentes potenciais hídricos, e coeficiente de variação.

\begin{tabular}{|c|c|c|c|c|c|}
\hline \multirow{2}{*}{$\begin{array}{c}\text { Potenciais } \\
\text { Hidricos } \\
\mathrm{MPa}\end{array}$} & \multirow{2}{*}{$\begin{array}{c}\text { Períodos } \\
\text { de absorção } \\
\text { h }\end{array}$} & \multicolumn{3}{|c|}{ Teores de água ( $\mathrm{g} / \mathrm{kg}$ de sementes) } & \multirow[t]{2}{*}{ Médias } \\
\hline & & 90 & 110 & 130 & \\
\hline \multirow{7}{*}{-0.04} & 2 & 11.5 & 8.4 & 5.1 & $8.3 \mathrm{~b}$ \\
\hline & 4 & 8.4 & 6.6 & 6.1 & $7.0 \mathrm{~cd}$ \\
\hline & 6 & 9.2 & 6.5 & 5.9 & $7.2 \mathrm{~cd}$ \\
\hline & 9 & 8.9 & 4.1 & 3.8 & $5.6 b c$ \\
\hline & 12 & 7.2 & 4.9 & 4.0 & $5.4 a b c$ \\
\hline & 18 & 5.0 & 2.9 & 2.9 & $3.6 \mathrm{a}$ \\
\hline & 24 & 6.5 & 3.1 & 3.2 & $4.3 \mathrm{ab}$ \\
\hline Médias & & $8.1 \mathrm{~B}$ & $5.2 \mathrm{~A}$ & $4.4 \mathrm{~A}$ & \\
\hline C.V. $(\%)$ & & 26.3 & & & \\
\hline \multirow{7}{*}{$-0,10$} & 2 & $11.0 \mathrm{Cd}$ & $7.9 \mathrm{Bc}$ & $4.0 \mathrm{Aa}$ & 7.6 \\
\hline & 4 & $8.0 \mathrm{Bbc}$ & $4.4 \mathrm{Aab}$ & $5.6 \mathrm{Aa}$ & 6.0 \\
\hline & 6 & $9.9 \mathrm{Ccd}$ & $6.7 \mathrm{Bbc}$ & $3.8 \mathrm{Aa}$ & 6.8 \\
\hline & 9 & $8.2 \mathrm{Bbc}$ & $4.4 \mathrm{Aab}$ & $4.5 \mathrm{Aa}$ & 5.7 \\
\hline & 12 & 4.7 Aab & $4.7 \mathrm{Aab}$ & $3.9 \mathrm{Aa}$ & 4.4 \\
\hline & 18 & $5.2 \mathrm{Aa}$ & $4.3 \mathrm{Aab}$ & $3.8 \mathrm{Aa}$ & 4.5 \\
\hline & 24 & $6.3 \mathrm{Bab}$ & $3.1 \mathrm{Aa}$ & $3.0 \mathrm{Aa}$ & 4.1 \\
\hline Médias & & 7.6 & 5.1 & 4.1 & \\
\hline C.V. $(\%)$ & & 22.9 & & & \\
\hline \multirow{7}{*}{-0.20} & 2 & $10.9 \mathrm{Cc}$ & $7 \therefore B C$ & $4.4 \mathrm{Aab}$ & 7.4 \\
\hline & 4 & $7.4 \mathrm{Aab}$ & $\therefore \quad a b c$ & $5.6 \mathrm{Ab}$ & 6.6 \\
\hline & 6 & $7.0 \mathrm{Bab}$ & $\div$ Aabc & $4.4 \mathrm{Aab}$ & 5.4 \\
\hline & 9 & $8.5 \mathrm{Bbc}$ & $+.1 \mathrm{Aa}$ & $3.9 \mathrm{Aab}$ & 5.5 \\
\hline & 12 & $5.0 \mathrm{Ba}$ & $+.5 \mathrm{ABab}$ & $2.8 \mathrm{Aa}$ & 4.1 \\
\hline & 18 & $6.0 \mathrm{Ba}$ & $3.4 \mathrm{Aa}$ & $2.7 \mathrm{Aa}$ & 4.0 \\
\hline & 24 & $5.4 \mathrm{Aa}$ & $4.7 \mathrm{Aabc}$ & $3.7 \mathrm{Aab}$ & 4.6 \\
\hline Médias & & 7.1 & 5.0 & 4.0 & \\
\hline C.V. $(\%)$ & & 20.7 & & & \\
\hline \multirow{7}{*}{-0.40} & 2 & $10.2 \mathrm{Bb}$ & $4.3 \mathrm{Aa}$ & $3.2 \mathrm{Aa}$ & 5.9 \\
\hline & 4 & 7.2 $\mathrm{Bab}$ & $3.6 \mathrm{Aa}$ & $2.8 \mathrm{Aa}$ & 4.5 \\
\hline & 6 & 7.0 Aab & $5.4 \mathrm{Aa}$ & $4.8 \mathrm{Aa}$ & 5.7 \\
\hline & 9 & $5.6 \mathrm{Aa}$ & $3.5 \mathrm{Aa}$ & $3.4 \mathrm{Aa}$ & 4.2 \\
\hline & 12 & $6.8 \mathrm{Bab}$ & $3.9 \mathrm{ABa}$ & $3.7 \mathrm{Aa}$ & 4.8 \\
\hline & 18 & $4.1 \mathrm{Aa}$ & $3.6 \mathrm{Aa}$ & 3.1 Aa & 3.6 \\
\hline & 24 & $3.8 \mathrm{Aa}$ & $3.0 \mathrm{Aa}$ & $3.5 \mathrm{Aa}$ & 3.4 \\
\hline Médias & & 64 & 3.9 & 3.5 & \\
\hline C.V. $(\%)$ & & 37.9 & & & \\
\hline
\end{tabular}

Letras minusculas: comparações entre médias dentro de cada coluna.

Letras maiusculas: comparações entre médias dentro de cada linha. 
Tabela 31. Liberação de íons: valores médios $(\mu \mathrm{mhos} / \mathrm{cm} / \mathrm{g})$ obtidos para o lote 2 de sementes de soja do cultivar IAC-15, com teores de água ajustados, após exposição à combinação entre períodos de absorção de água e diferentes potenciais hídricos, e coeficiente de variação.

\begin{tabular}{|c|c|c|c|c|c|}
\hline \multirow{2}{*}{$\begin{array}{c}\text { Potenciais } \\
\text { Hidricos } \\
\text { MPa }\end{array}$} & \multirow{2}{*}{$\begin{array}{c}\text { Periodos } \\
\text { de absorção } \\
\text { h }\end{array}$} & \multicolumn{3}{|c|}{ Teores de água ( $\mathrm{g} / \mathrm{kg}$ de sementes) } & \multirow[t]{2}{*}{ Médias } \\
\hline & & 90 & 110 & 130 & \\
\hline \multirow{7}{*}{$-0,04$} & 2 & 12.0 & 9.6 & 6.8 & $9.5 \mathrm{c}$ \\
\hline & 4 & 10.2 & 5.6 & 5.5 & $7.1 \mathrm{bc}$ \\
\hline & 6 & 9.5 & 5.7 & 5.1 & $6.8 \mathrm{bc}$ \\
\hline & 9 & 9.4 & 5.0 & 4.5 & $6.3 \mathrm{ab}$ \\
\hline & 12 & 7.5 & 5.3 & 4.3 & $5.7 \mathrm{ab}$ \\
\hline & 18 & 5.1 & 3.5 & 3.3 & $4.0 \mathrm{a}$ \\
\hline & 24 & 6.4 & 5.8 & 4.8 & $5.7 \mathrm{ab}$ \\
\hline Médias & & $8.6 \mathrm{~B}$ & $5.8 \mathrm{~A}$ & $4.9 \mathrm{~A}$ & \\
\hline C.V. $(\%)$ & & 31.1 & & & \\
\hline \multirow{7}{*}{$-.0,10$} & 2 & 10.5 & 6.7 & 6.7 & $7.9 \mathrm{~b}$ \\
\hline & 4 & 8.3 & 7.5 & 5.1 & $6.9 \mathrm{~b}$ \\
\hline & 6 & 6.4 & 4.6 & 4.5 & $5.2 \mathrm{a}$ \\
\hline & 9 & 6.1 & 4.5 & 4.2 & $5.0 \mathrm{a}$ \\
\hline & 12 & 5.4 & 5.3 & 5.1 & $5.3 \mathrm{a}$ \\
\hline & 18 & 5.1 & 4.4 & 2.7 & $4.0 \mathrm{a}$ \\
\hline & 24 & 4.3 & 3.9 & 3.8 & $4.0 \mathrm{a}$ \\
\hline Médias & & $6.6 \mathrm{~B}$ & $5.2 \mathrm{~A}$ & $4.6 \mathrm{~A}$ & \\
\hline C.V. $(\%)$ & & 24.4 & & & \\
\hline \multirow{7}{*}{$-0,20$} & 2 & 10.5 & 9.6 & 8.8 & $9.6 \mathrm{~b}$ \\
\hline & 4 & 8.6 & 8.2 & 8.0 & $8.2 \mathrm{~b}$ \\
\hline & 6 & 6.3 & 5.5 & 4.3 & $5.3 \mathrm{a}$ \\
\hline & 9 & 5.7 & 5.5 & 5.1 & $5.4 \mathrm{a}$ \\
\hline & 12 & 5.9 & 5.5 & 5.4 & $5.6 \mathrm{a}$ \\
\hline & 18 & 4.5 & 4.5 & 3.9 & $4.3 \mathrm{a}$ \\
\hline & 24 & 4.2 & 3.6 & 3.1 & $3.6 \mathrm{a}$ \\
\hline Médias & & $6.5 \mathrm{~A}$ & $6.0 \mathrm{~A}$ & $5.5 \mathrm{~A}$ & \\
\hline C.V $(\%)$ & & 31.4 & & & \\
\hline \multirow{7}{*}{$-0,40$} & 2 & $9.8 \mathrm{Bc}$ & $8.9 \mathrm{Bc}$ & $6.7 \mathrm{Ab}$ & 8.5 \\
\hline & 4 & $7.2 \mathrm{Bbc}$ & $3.2 \mathrm{Aa}$ & $2.7 \mathrm{Aa}$ & 4.4 \\
\hline & 6 & $6.9 \mathrm{Bab}$ & $5.6 \mathrm{ABab}$ & $4.5 \mathrm{Aab}$ & 5.6 \\
\hline & 9 & $6.5 \mathrm{Aab}$ & $6.7 \mathrm{Abc}$ & $5.4 \mathrm{Aab}$ & 6.2 \\
\hline & 12 & $5.4 \mathrm{Aab}$ & $5.1 \mathrm{Aab}$ & $4.7 \mathrm{Aab}$ & 5.1 \\
\hline & 18 & $5.1 \mathrm{Aab}$ & $4.3 \mathrm{Aab}$ & $4.2 \mathrm{Aab}$ & 4.5 \\
\hline & 24 & $4.3 \mathrm{Aa}$ & $4.2 \mathrm{Aab}$ & $3.8 \mathrm{Aa}$ & 4.1 \\
\hline Média & & 6.5 & 5.4 & 4.6 & \\
\hline C.V. $(\%)$ & & 22.8 & & & \\
\hline
\end{tabular}

Letras minúsculas: comparações entre médias dentro de cada coluna.

Letras maiusculas: comparações entre médias dentro de cada linha. 
Tabela 32. Liberação de íons: valores médios ( $\mu$ mhos $/ \mathrm{cm} / \mathrm{g}$ ) obtidos para o lote 3 de sementes de soja do cultivar IAC-15, com teores de água ajustados, após exposição à combinação entre períodos de absorção de água e diferentes potenciais hídricos, e coeficiente de variação.

\begin{tabular}{|c|c|c|c|c|c|}
\hline \multirow{2}{*}{$\begin{array}{c}\text { Potenciais } \\
\text { Hidricos } \\
\mathrm{MPa} \\
\end{array}$} & \multirow{2}{*}{$\begin{array}{c}\text { Períodos } \\
\text { de absorção } \\
\text { b }\end{array}$} & \multicolumn{3}{|c|}{ Teores de água ( $\mathrm{g} / \mathrm{kg}$ de sementes) } & \multirow[t]{2}{*}{ Médias } \\
\hline & & 90 & 110 & 130 & \\
\hline \multirow{7}{*}{$-0,04$} & 2 & 11.0 & 10.8 & 10.6 & $10.8 \mathrm{~b}$ \\
\hline & 4 & 9.4 & 8.2 & 8.9 & $8.8 \mathrm{ab}$ \\
\hline & 6 & 8.1 & 6.8 & 6.1 & $7.0 \mathrm{a}$ \\
\hline & 9 & 7.8 & 6.8 & 6.3 & $7.0 \mathrm{a}$ \\
\hline & 12 & 8.2 & 7.2 & 6.3 & $7.2 \mathrm{a}$ \\
\hline & 18 & 8.4 & 7.2 & 6.4 & $7.3 \mathrm{a}$ \\
\hline & 24 & 7.4 & 6.6 & 6.4 & $6.8 \mathrm{a}$ \\
\hline Médias & & $8.6 \mathrm{~A}$ & $7.6 \mathrm{~A}$ & $7.3 \mathrm{~A}$ & \\
\hline C.V. $(\%)$ & & 26.9 & & & \\
\hline \multirow{7}{*}{$-.0 .10$} & 2 & 11.0 & 10.2 & 9.5 & $10.2 \mathrm{~b}$ \\
\hline & 4 & 8.7 & 8.4 & 6.5 & $7.9 \mathrm{ab}$ \\
\hline & 6 & 8.2 & 7.2 & 6.5 & $7.3 \mathrm{a}$ \\
\hline & 9 & 8.4 & 7.7 & 6.9 & $7.7 \mathrm{ab}$ \\
\hline & 12 & 8.9 & 7.9 & 6.9 & $7.9 \mathrm{ab}$ \\
\hline & 18 & 8.1 & 6.7 & 64 & $7.0 \mathrm{a}$ \\
\hline & 24 & 6.9 & 6.6 & 6.3 & $6.6 \mathrm{a}$ \\
\hline Médias & & $8.6 \mathrm{~B}$ & $7.8 \mathrm{AB}$ & $7.0 \mathrm{~A}$ & \\
\hline C.V. $(\%)$ & & 29.8 & & & \\
\hline \multirow{7}{*}{-0.20} & 2 & 11.0 & 9.4 & 8.8 & $9.7 \mathrm{c}$ \\
\hline & 4 & 8.4 & 8.3 & 6.6 & $7.7 \mathrm{bc}$ \\
\hline & 6 & 7.5 & 8.1 & 6.8 & $7.5 \mathrm{abc}$ \\
\hline & 9 & 7.3 & 6.2 & 5.8 & $6.4 a b$ \\
\hline & 12 & 7.4 & 5.8 & 5.9 & $64 a b$ \\
\hline & 18 & 6.8 & 6.5 & 5.9 & $6.4 \mathrm{a}$ \\
\hline & 24 & 5.5 & 5.6 & 4.7 & $5.2 \mathrm{a}$ \\
\hline Médias & & $7.7 \mathrm{~B}$ & $7.1 \mathrm{AB}$ & $6.3 \mathrm{~A}$ & \\
\hline C.V. $(\%)$ & & 26.3 & & & \\
\hline \multirow{7}{*}{-0.40} & 2 & 10.0 & 9.0 & 8.2 & $9.1 \mathrm{c}$ \\
\hline & 4 & 8.2 & 7.9 & 6.4 & $7.5 \mathrm{~b}$ \\
\hline & 6 & 7.7 & 7.4 & 6.1 & $7.1 \mathrm{ab}$ \\
\hline & 9 & 6.3 & 6.2 & 5.7 & $6.0 \mathrm{ab}$ \\
\hline & 12 & 6.7 & 5.9 & 5.5 & $6.0 \mathrm{ab}$ \\
\hline & 18 & $6+$ & 5.8 & 5.3 & $5.8 \mathrm{a}$ \\
\hline & 24 & 6.6 & 5.8 & 4.9 & $5.7 \mathrm{a}$ \\
\hline Medias & & $7 .+B$ & $6.8 \mathrm{~A}$ & $5.9 \mathrm{~A}$ & \\
\hline$C . V(\%)$ & & 18.1 & & & \\
\hline
\end{tabular}

Letras minusculas: comparaçōes entre médias dentro de cada coluna.

Letras maiusculas: comparações entre medias dentro de cada linha 


\subsubsection{Deterioração por "umidade"}

Os resultados das análises da variância referentes aos testes realizados para avaliação da ocorrência dos sintomas de deterioração por "umidade" nas sementes dos três lotes, com 90, 100 e $130 \mathrm{~g}$ de água $/ \mathrm{kg}$ de sementes úmidas, estão apresentados nas Tabelas 33 a 35 .

Observaram-se, para os lotes 1 e 2, valores de F não significativos para os efeitos de Períodos de absorção de água, para os efeitos de Teores de água e para o efeito da interação Períodos de absorção de água $\mathrm{x}$ Teores de água sobre a viabilidade (TZ 1-5) após exposição das sementes aos diferentes potenciais hídricos do substrato (Tabelas 33 e 34). No entanto, para o lote 3, constatataram-se valores de F significativos para os efeitos de Períodos de absorção de água sobre a viabilidade após exposição a potenciais hídricos de $-0,20$ e $-0,40 \mathrm{MPa}$ e, valor de $\mathrm{F}$ significativo para o efeito da interação Períodos de absorção de água x Teores de água sobre a viabilidade após exposição das sementes aos potenciais hídricos de -0,04 e -0,10 MPa (Tabela 35).

Além disso, verificaram-se valores de $\mathrm{F}$ altamente significativos para o efeito da interação Períodos de embebição $\mathrm{x}$ Teores de água sobre os sintomas de deterioração nas sementes viáveis (TZ 1-5) após exposição das sementes do lote 1 aos potenciais hídricos de $-0,10,-0,20$ e $-0,40 \mathrm{MPa}$ (Tabela 33); após exposição das sementes do lote 2 ao potencial hídrico de -0,40 MPa (Tabela 34) e, após exposição das sementes do lote 3 ao potencial hídrico de $-0,10 \mathrm{MPa}$ (Tabela 35). Observaram-se, também, valores de $\mathrm{F}$ altamente significativos para os efeitos de Teores de água sobre os sintomas de deterioração por "umidade", após exposição das sementes do lote 1 ao potencial hídrico de -0,04 MPa (Tabela 33) e após exposição das sementes do lote 2 aos potenciais hídricos de -0,10 e -0,20 MPa (Tabela 34). 
Tabela 33. Valores de $\mathrm{F}$ obtidos nas análises da variância dos dados referentes a viabilidade e a detecção de sintomas de deterioração por "umidade" nas sementes viávies para avaliação dos danos por embebição, após exposição à combinação entre determinados períodos de absorção de água e diferentes potenciais hídricos. para o lote 1 .

\begin{tabular}{|c|c|c|c|}
\hline $\begin{array}{l}\text { Potenciais Hidricos } \\
\qquad(\mathrm{MPa})\end{array}$ & Causas da Variação & $\begin{array}{c}\text { Viabilidade } \\
(\%)\end{array}$ & $\begin{array}{c}\text { Sintomas } \\
(\%)\end{array}$ \\
\hline$-0,04$ & $\begin{array}{l}\text { Periodos }(\mathrm{P}) \\
\text { Teores de água }(\mathrm{A}) \\
\text { P X A }\end{array}$ & $\begin{array}{l}1.3965 \mathrm{~ns} \\
2.7331 \mathrm{~ns} \\
1.1424 \mathrm{~ns}\end{array}$ & $\begin{array}{l}1.7200^{\mathrm{ns}} \\
30.7035^{* *} \\
2.2483^{\mathrm{ns}}\end{array}$ \\
\hline$-0,10$ & $\begin{array}{l}\text { Periodos }(\mathrm{P}) \\
\text { Teores de água }(\mathrm{A}) \\
\text { P X A }\end{array}$ & $\begin{array}{l}0.6473 \mathrm{~ns} \\
0.8937 \mathrm{~ns} \\
2.2998 \mathrm{~ns}\end{array}$ & $\begin{array}{l}8.2551^{* *} \\
53.9156^{* *} \\
3.5409^{* *}\end{array}$ \\
\hline$-0,20$ & $\begin{array}{l}\text { Periodos }(\mathrm{P}) \\
\text { Teores de água }(\mathrm{A}) \\
\mathrm{PXA}\end{array}$ & $\begin{array}{l}2.4182 \mathrm{~ns} \\
3.2287 \mathrm{~ns} \\
0.4313 \mathrm{~ns}\end{array}$ & $\begin{array}{r}3.0375^{*} \\
85.8728^{* *} \\
4.5658^{* *}\end{array}$ \\
\hline$-0,40$ & $\begin{array}{l}\text { Periodos }(\mathrm{P}) \\
\text { Teores de água }(\mathrm{A}) \\
\text { PXA }\end{array}$ & $\begin{array}{l}1.2506 \mathrm{~ns} \\
0.2481 \mathrm{~ns} \\
0.4616^{\mathrm{ns}}\end{array}$ & $\begin{array}{c}0.8806^{\mathrm{ns}} \\
48.2289^{* * *} \\
5.8843^{* *}\end{array}$ \\
\hline
\end{tabular}

* significativo ao nivel de $5 \%$ de probabilidade: ${ }^{* *}$ significativo ao nivel de $1 \%$ de probabilidade; ns não significativo 
Tabela 34. Valores de $\mathrm{F}$ obtidos nas análises da variância dos dados referentes a viabilidade e a detecção de sintomas de deterioração por "umidade" nas sementes viáveis para avaliação dos danos por embebição, após exposição à combinação entre determinados períodos de absorção de água e diferentes potenciais hídricos, para o lote 2 .

\begin{tabular}{|c|c|c|c|}
\hline $\begin{array}{l}\text { Potenciais Hidricos } \\
\text { (MPa) }\end{array}$ & Causas da Variação & $\begin{array}{c}\text { Viabilidade } \\
(\%)\end{array}$ & $\begin{array}{c}\text { Sintomas } \\
(\%)\end{array}$ \\
\hline$-0,04$ & $\begin{array}{l}\text { Periodos }(\mathrm{P}) \\
\text { Teores de água }(\mathrm{A}) \\
\text { P X A }\end{array}$ & $\begin{array}{l}1.5849 \mathrm{~ns} \\
0.5427 \mathrm{~ns} \\
1.4046 \mathrm{~ns}\end{array}$ & $\begin{array}{l}1.3132 \mathrm{~ns} \\
1.2682 \mathrm{~ns} \\
1.2948 \mathrm{~ns}\end{array}$ \\
\hline$-0,10$ & $\begin{array}{l}\text { Periodos }(\mathrm{P}) \\
\text { Teores de água }(\mathrm{A}) \\
\text { P X A }\end{array}$ & $\begin{array}{l}0.2339 \mathrm{~ns} \\
0.3899 \mathrm{~ns} \\
0.2553 \mathrm{~ns}\end{array}$ & $\begin{array}{c}2.2454^{\mathrm{ns}} \\
18.7680^{* *} \\
1.9791^{\mathrm{ns}}\end{array}$ \\
\hline$-0,20$ & $\begin{array}{l}\text { Periodos }(\mathrm{P}) \\
\text { Teores de água }(\mathrm{A}) \\
\text { P X A }\end{array}$ & $\begin{array}{l}1.2442 \mathrm{~ns} \\
0.7823 \mathrm{~ns} \\
2.2622 \mathrm{~ns}\end{array}$ & $\begin{array}{l}0.9041 \mathrm{~ns} \\
5.9325^{* *} \\
2.0445 \mathrm{~ns}\end{array}$ \\
\hline$-0,40$ & $\begin{array}{l}\text { Periodos }(\mathrm{P}) \\
\text { Teores de água }(\mathrm{A}) \\
\text { P X A }\end{array}$ & $\begin{array}{l}0.4440^{\mathrm{ns}} \\
0.4118^{\mathrm{ns}} \\
1.1131^{\mathrm{ns}}\end{array}$ & $\begin{array}{c}2.3512^{\mathrm{ns}} \\
0.0209 \mathrm{~ns} \\
6.6299^{*}\end{array}$ \\
\hline
\end{tabular}

* significativo ao nivel de $5 \%$ de probabilidade; ${ }^{* *}$ significativo ao nivel de $1 \%$ de probabilidade; ns não significativo 
Tabela 35. Valores de $\mathrm{F}$ obtidos nas análises da variância dos dados referentes a viabilidade e a deteç̧ão de sintomas de deterioração por "umidade" nas sementes viavéis para avaliação dos danos por embebição, após exposição à combinação entre determinados períodos de absorção de água e diferentes potenciais hídricos, para o lote 3 .

\begin{tabular}{|c|c|c|c|}
\hline $\begin{array}{l}\text { Potenciais Hidricos } \\
\qquad(\mathrm{MPa})\end{array}$ & Causas da Variação & $\begin{array}{c}\text { Viabilidade } \\
(\%)\end{array}$ & $\begin{array}{c}\text { Sintomas } \\
(\%)\end{array}$ \\
\hline$-0,04$ & $\begin{array}{l}\text { Períodos }(\mathrm{P}) \\
\text { Teores de água }(\mathrm{A}) \\
\text { P X A }\end{array}$ & $\begin{array}{l}0.7075 \mathrm{~ns} \\
1.2681^{\mathrm{ns}} \\
3.1156^{*}\end{array}$ & $\begin{array}{l}1.0503 \mathrm{~ns} \\
0.0001 \mathrm{~ns} \\
0.8995 \mathrm{~ns}\end{array}$ \\
\hline$-0,10$ & $\begin{array}{l}\text { Periodos }(\mathrm{P}) \\
\text { Teores de água }(\mathrm{A}) \\
\mathrm{P} X \mathrm{~A}\end{array}$ & $\begin{array}{l}2.7699^{*} \\
4.3700^{*} \\
2.5445^{*}\end{array}$ & $\begin{array}{l}3.5806^{*} \\
5.0867^{*} \\
2.6242^{*}\end{array}$ \\
\hline-0.20 & $\begin{array}{l}\text { Periodos (P) } \\
\text { Teores de água (A) } \\
\text { P X A }\end{array}$ & $\begin{array}{l}8.3671^{* *} \\
0.9453^{\mathrm{ns}} \\
2.2041^{\mathrm{ns}}\end{array}$ & $\begin{array}{l}4.7285^{* *} \\
1.2644 \text { ns } \\
0.7131 \text { ns }\end{array}$ \\
\hline-0.40 & $\begin{array}{l}\text { Periodos }(\mathrm{P}) \\
\text { Teores de água }(\mathrm{A}) \\
\mathrm{P} X \mathrm{~A}\end{array}$ & $\begin{array}{l}3.5612^{*} \\
1.2146^{\mathrm{ns}} \\
1.1710^{\mathrm{ns}}\end{array}$ & $\begin{array}{l}1.7892 \mathrm{~ns} \\
0.5090 \mathrm{~ns} \\
1.3964 \mathrm{~ns}\end{array}$ \\
\hline
\end{tabular}

* significativo ao nivel de $5 \%$ de probabilidade: ${ }^{* *}$ significativo ao nivel de $1 \%$ de probabilidade: ns nào significativo 
Pelas Tabelas 36 e 37, constatou-se que a viabilidade das sementes dos lotes 1 e 2 não diferiu durante as 18 horas de absorção de água, para os quatro potenciais hídricos do substrato e para os três teores de água estudados. Além disso, a viabilidade das sementes que apresentavam-se com menor teor de água, $90 \mathrm{~g} / \mathrm{kg}$, não diferiu da apresentada pelas sementes mais úmidas ( 110 e $130 \mathrm{~g}$ de água $/ \mathrm{kg}$ ).

A viabilidade das sementes do lote 3 , para os três teores de água estudados, não diferiu após os períodos de embebição sob a influência dos potenciais hídricos de $\quad-0,20$ e $-0,40 \mathrm{MPa}$ (Tabela 38 ), embora, para esse último potencial hídrico, tenha apresentado significância pelo teste $\mathrm{F}$ (Tabela 35). Além disso, a viabilidade das sementes desse lote, que apresentavam-se com menor teor de água, 90 $\mathrm{g} / \mathrm{kg}$, não diferiu da apresentada pelas sementes mais úmidas (110 e $130 \mathrm{~g}$ de água $/ \mathrm{kg}$ ) sob os mesmos potenciais hídricos de $-0,20$ e $-0,40 \mathrm{MPa}$.

Sob plena disponibilidade hídrica, a ocorrência de sintomas de deterioração por "umidade" nas sementes do lote 1, de qualidade fisiológica superior aos demais, não diferiu nas primeiras 18 horas de embebição sob o potencial hídrico de $-0,04$ MPa, para os três teores de água estudados (Tabela 39). Além disso, as sementes, com menor teor inicial de água, $90 \mathrm{~g} / \mathrm{kg}$, apresentaram maior ocorrência de sintomas de deterioração por "umidade" em relação as com $130 \mathrm{~g} / \mathrm{kg}$ e, não diferiram das com 110 $\mathrm{g} / \mathrm{kg}$ (Tabela 39), porém esses sintomas de deterioração por "umidade" apresentados pelas sementes com $90 \mathrm{~g}$ de água $/ \mathrm{kg}$ não afetaram a viabilidade (Tabela 36). Desta forma, pode-se inferir que o aumento do teor de água das sementes do lote 1 proporcionou a redução da ocorrência de sintomas de deterioração por "umidade" (Tabela 39), assim como a redução da liberação de íons sob plena disponibilidade hídrica (Tabela 30). 
Tabela 36. Viabilidade (TZ 1-5): valores médios (\%) obtidos para o lote 1 de sementes de soja do cultivar IAC-15, com teores de água ajustados, após exposição à combinação entre períodos de absorção de água e diferentes potenciais hídricos, e coeficiente de variação.

\begin{tabular}{|c|c|c|c|c|c|}
\hline \multirow{2}{*}{$\begin{array}{c}\text { Potenciais } \\
\text { Hidricos } \\
\mathrm{MPa}\end{array}$} & \multirow{2}{*}{$\begin{array}{c}\text { Periodos de } \\
\text { absorção } \\
\text { h }\end{array}$} & \multicolumn{3}{|c|}{ Teores de agua ( $\mathrm{g} / \mathrm{kg}$ de sementes) } & \multirow[t]{2}{*}{ Médias } \\
\hline & & 90 & 110 & 130 & \\
\hline \multirow{6}{*}{$-0,04$} & 2 & 95 & 96 & 99 & $97 \mathrm{a}$ \\
\hline & 4 & 97 & 98 & 98 & $98 \mathrm{a}$ \\
\hline & 6 & 95 & 98 & 98 & 97 a \\
\hline & 9 & 96 & 95 & 98 & 96 a \\
\hline & 12 & 97 & 100 & 98 & $98 \mathrm{a}$ \\
\hline & 18 & 99 & 97 & 99 & $98 \mathrm{a}$ \\
\hline Médias & & $97 \mathrm{~A}$ & $97 \mathrm{~A}$ & $98 \mathrm{~A}$ & \\
\hline C.V. $(\%)$ & & 5.3 & & & \\
\hline \multirow{6}{*}{-0.10} & 2 & 95 & 96 & 98 & 96 a \\
\hline & 4 & 96 & 96 & 98 & 97 a \\
\hline & 6 & 96 & 99 & 97 & $97 \mathrm{a}$ \\
\hline & 9 & 98 & 95 & 100 & 98 a \\
\hline & 12 & 97 & 99 & 96 & 97 a \\
\hline & 18 & 98 & 97 & 96 & $97 \mathrm{a}$ \\
\hline Médias & & $97 \mathrm{~A}$ & $97 \mathrm{~A}$ & $98 \mathrm{~A}$ & \\
\hline C.V. $(\%)$ & & 4.8 & & & \\
\hline \multirow{6}{*}{$-0,20$} & 2 & 95 & 96 & 96 & $96 \mathrm{a}$ \\
\hline & 4 & 95 & 96 & 96 & $96 \mathrm{a}$ \\
\hline & 6 & 96 & 98 & 98 & 97 a \\
\hline & 9 & 97 & 98 & 99 & $98 \mathrm{a}$ \\
\hline & 12 & 97 & 100 & 98 & 98 a \\
\hline & 18 & 98 & 99 & 98 & $98 \mathrm{a}$ \\
\hline Medias & & $96 \mathrm{~A}$ & $98 \mathrm{~A}$ & $98 \mathrm{~A}$ & \\
\hline C.V. $(\%)$ & & 5.3 & & & \\
\hline \multirow{6}{*}{$-0,40$} & 2 & 96 & 96 & 96 & $96 \mathrm{a}$ \\
\hline & 4 & 96 & 96 & 96 & $96 a$ \\
\hline & 6 & 96 & 96 & 97 & $96 \mathrm{a}$ \\
\hline & 9 & 98 & 96 & 96 & $97 \mathrm{a}$ \\
\hline & 12 & 98 & 98 & 97 & $98 \mathrm{a}$ \\
\hline & 18 & 98 & 97 & 99 & $98 \mathrm{a}$ \\
\hline Médias & & $97 \mathrm{~A}$ & $97 \mathrm{~A}$ & $97 \mathrm{~A}$ & \\
\hline C.V. $(\%)$ & & 5.4 & & & \\
\hline
\end{tabular}

Letras minúsculas: comparaçǒes entre médias dentro de cada coluna.

Letras maiúsculas: comparações entre médias dentro de cada linha. 
Tabela 37. Viabilidade (TZ 1-5): valores médios (\%) obtidos para o lote 2 de sementes de soja do cultivar IAC-15, com teores de água ajustados, após exposição à combinação entre períodos de absorção de água e diferentes potenciais hídricos, e coeficiente de variação.

\begin{tabular}{|c|c|c|c|c|c|}
\hline \multirow{2}{*}{$\begin{array}{c}\text { Potenciais } \\
\text { Hídricos } \\
\mathrm{MPa}\end{array}$} & \multirow{2}{*}{$\begin{array}{c}\text { Periodos de } \\
\text { absorção } \\
\text { h }\end{array}$} & \multicolumn{3}{|c|}{ Teores de água ( $\mathrm{g} / \mathrm{kg}$ de sementes) } & \multirow[t]{2}{*}{ Médias } \\
\hline & & 90 & 110 & 130 & \\
\hline \multirow{6}{*}{$-0,04$} & 2 & 92 & 92 & 94 & 93 a \\
\hline & 4 & 94 & 94 & 94 & $94 \mathrm{a}$ \\
\hline & 6 & 92 & 94 & 94 & $94 \mathrm{a}$ \\
\hline & 9 & 94 & 92 & 94 & $93 \mathrm{a}$ \\
\hline & 12 & 95 & 94 & 94 & $94 \mathrm{a}$ \\
\hline & 18 & 94 & 94 & 94 & $94 \mathrm{a}$ \\
\hline Médias & & $94 \mathrm{~A}$ & $93 \mathrm{~A}$ & $94 \mathrm{~A}$ & \\
\hline C.V. $(\%)$ & & 1.60 & & & \\
\hline \multirow{6}{*}{$-.0,10$} & 2 & 93 & 94 & 94 & $94 \mathrm{a}$ \\
\hline & 4 & 94 & 94 & 94 & $94 \mathrm{a}$ \\
\hline & 6 & 92 & 95 & 94 & $94 \mathrm{a}$ \\
\hline & 9 & 94 & 95 & 94 & $94 \mathrm{a}$ \\
\hline & 12 & 95 & 94 & 95 & $95 \mathrm{a}$ \\
\hline & 18 & 94 & 94 & 93 & $94 \mathrm{a}$ \\
\hline Médias & & $94 \mathrm{~A}$ & $94 \mathrm{~A}$ & $94 \mathrm{~A}$ & \\
\hline C.V. $(\%)$ & & 3.36 & & & \\
\hline \multirow{6}{*}{$-0,20$} & 2 & 94 & 92 & 94 & $93 \mathrm{a}$ \\
\hline & 4 & 97 & 94 & 95 & $95 \mathrm{a}$ \\
\hline & 6 & 94 & 97 & 94 & $95 \mathrm{a}$ \\
\hline & 9 & 95 & 95 & 94 & $95 \mathrm{a}$ \\
\hline & 12 & 92 & 97 & 93 & $94 \mathrm{a}$ \\
\hline & 18 & 94 & 94 & 95 & $94 \mathrm{a}$ \\
\hline Médias & & $94 \mathrm{~A}$ & $95 \mathrm{~A}$ & $94 \mathrm{~A}$ & \\
\hline C.V. $(\%)$ & & 3.68 & & & \\
\hline \multirow{6}{*}{$-0,40$} & 2 & 92 & 94 & 94 & $93 \mathrm{a}$ \\
\hline & 4 & 96 & 93 & 93 & $94 \mathrm{a}$ \\
\hline & 6 & 93 & 94 & 95 & $94 \mathrm{a}$ \\
\hline & 9 & 93 & 95 & 94 & $94 \mathrm{a}$ \\
\hline & 12 & 94 & 94 & 95 & $94 \mathrm{a}$ \\
\hline & 18 & 94 & 95 & 95 & $95 \mathrm{a}$ \\
\hline Médias & & $94 \mathrm{~A}$ & $94 \mathrm{~A}$ & $94 \mathrm{~A}$ & \\
\hline C.V. $(\%)$ & & 2.59 & & & \\
\hline
\end{tabular}

Letras minúsculas: comparações entre médias dentro de cada coluna.

Letras maiúsculas: comparações entre médias dentro de cada linha. 
Tabela 38. Viabilidade (TZ 1-5): valores médios (\%) obtidos para o lote 3 de sementes de soja do cultivar IAC-15, com teores de água ajustados, após exposição à combinação entre períodos de absorção de água e diferentes potenciais hídricos, e coeficiente de variação.

\begin{tabular}{|c|c|c|c|c|c|}
\hline \multirow{2}{*}{$\begin{array}{l}\text { Potenciais } \\
\text { Hidricos } \\
\mathrm{MPa}\end{array}$} & \multirow{2}{*}{$\begin{array}{c}\text { Periodos de } \\
\text { absorção } \\
h\end{array}$} & \multicolumn{3}{|c|}{ Teores de água ( $\mathrm{g} / \mathrm{kg}$ de sementes) } & \multirow[t]{2}{*}{ Médias } \\
\hline & & 90 & 110 & 130 & \\
\hline \multirow{6}{*}{$-0,04$} & 2 & $88 \mathrm{Aa}$ & $91 \mathrm{Ab}$ & $89 \mathrm{Aab}$ & 89 \\
\hline & 4 & $90 \mathrm{Aa}$ & $91 \mathrm{Ab}$ & $91 \mathrm{Aab}$ & 91 \\
\hline & 6 & $91 \mathrm{Aa}$ & $89 \mathrm{Ab}$ & $88 \mathrm{Aa}$ & 89 \\
\hline & 9 & $91 \mathrm{Aa}$ & $88 \mathrm{Aab}$ & $89 \mathrm{Aab}$ & 89 \\
\hline & 12 & $89 \mathrm{Ba}$ & $88 \mathrm{Ba}$ & $93 \mathrm{Ab}$ & 90 \\
\hline & 18 & $93 \mathrm{Aa}$ & $89 \mathrm{Bb}$ & $88 \mathrm{Ba}$ & 90 \\
\hline Médias & & 90 & 89 & 90 & \\
\hline C.V. $(\%)$ & & 2.17 & & & \\
\hline \multirow{6}{*}{$-.0,10$} & 2 & $89 \mathrm{Aa}$ & $93 \mathrm{Abc}$ & $90 \mathrm{Aa}$ & 91 \\
\hline & 4 & $89 \mathrm{Aa}$ & $88 \mathrm{Aab}$ & $91 \mathrm{Aa}$ & 89 \\
\hline & 6 & $88 \mathrm{Ba}$ & $90 \mathrm{Bc}$ & $90 \mathrm{Aa}$ & 89 \\
\hline & 9 & $88 \mathrm{Aa}$ & $86 \mathrm{Aa}$ & $88 \mathrm{Aa}$ & 87 \\
\hline & 12 & $88 \mathrm{Aa}$ & $88 \mathrm{Aab}$ & $92 \mathrm{Aa}$ & 89 \\
\hline & 18 & $88 \mathrm{Aa}$ & $92 \mathrm{Aabc}$ & $91 \mathrm{Aa}$ & 90 \\
\hline Médias & & 88 & 90 & 90 & \\
\hline C.V. $(\%)$ & & 2.78 & & & \\
\hline \multirow{6}{*}{$-0,20$} & 2 & 90 & 94 & 91 & $92 \mathrm{ab}$ \\
\hline & 4 & 86 & 90 & 90 & $89 a$ \\
\hline & 6 & 92 & 96 & 94 & $94 \mathrm{~b}$ \\
\hline & 9 & 91 & 94 & 92 & $92 \mathrm{~b}$ \\
\hline & 12 & 90 & 93 & 89 & $91 \mathrm{~b}$ \\
\hline & 18 & 93 & 93 & 94 & $93 \mathrm{~b}$ \\
\hline Médias & & $90 \mathrm{~A}$ & $93 \mathrm{~A}$ & $92 \mathrm{~A}$ & \\
\hline C.V. $(\%)$ & & 3.65 & & & \\
\hline \multirow{6}{*}{$-0,40$} & 2 & 92 & 91 & 91 & $91 \mathrm{a}$ \\
\hline & 4 & 94 & 93 & 90 & $92 \mathrm{a}$ \\
\hline & 6 & 80 & 90 & 93 & $91 a$ \\
\hline & 9 & 90 & 89 & 93 & $91 \mathrm{a}$ \\
\hline & 12 & 96 & 91 & 94 & $95 a$ \\
\hline & 18 & 94 & 92 & 96 & $94 a$ \\
\hline Médias & & $93 \mathrm{~A}$ & $91 \mathrm{~A}$ & $93 \mathrm{~A}$ & \\
\hline C.V. $(\%)$ & & 3.51 & & & \\
\hline
\end{tabular}

Letras minusculas: comparações entre medias dentro de cada coluna.

Letras maiúsculas: comparações entre médias dentro de cada linha. 
A ocorrência de sintomas de deterioração por "umidade" nas sementes dos lotes 2 e 3 não diferiu nas primeiras 18 horas de embebição sob o potencial hídrico de 0,04 MPa, para os três teores de água estudados, como também observado para o lote 1 , de qualidade fisiológica superior a esses 2 lotes. Além disso, a ocorrência de sintomas de deterioração por "umidade" nas sementes com menor teor de água, $90 \mathrm{~g} / \mathrm{kg}$, não diferiu da ocorrência de sintomas de deterioração nas demais com 110 e $130 \mathrm{~g}$ de água $/ \mathrm{kg}$ (Tabelas 40 e 41). Assim, o aumento do teor de água para 110 e $130 \mathrm{~g} / \mathrm{kg}$ não interferiu na ocorrência de sintomas de deterioração após as primeiras 18 horas sob plena disponibilidade hídrica, assim como também não interferiu na liberação de íons das sementes do lote 3 , conforme as informações apresentadas na Tabela 32.

Quando a disponibilidade de água foi menor, ou seja, sob condição de hidratação mais lenta, a ocorrência de sintomas de deterioração por "umidade" nas sementes do lote 1 , que apresentavam-se com menor teor de água, foi mais acentuada durante as primeiras horas de embebição sob os potenciais hídricos de $-0,10$ e $-0,20 \mathrm{MPa}$ (Tabela 39).

Para as sementes do lote 2, quando a disponibidade bídrica foi menor, a ocorrência de sintomas por deterioração por "umidade" não diferiu durante as primeiras 18 horas de embebição sob potenciais hídricos de $-0,10$ e $-0,20 \mathrm{MPa}$, para os três teores de água estudados. Além disso, a ocorrência de sintomas de deterioração foi mais acentuada nas sementes com menor teor inicial de água, $90 \mathrm{~g} / \mathrm{kg}$, em relação às demais com 110 e $130 \mathrm{~g}$ de água/kg sob os mesmos potenciais hídricos de - $-0,10$ e $-0,20 \mathrm{MPa}$ (Tabela 40), porém esses sintomas apresentados pelas sementes com $90 \mathrm{~g}$ de água/kg não afetaram a viabilidade (Tabela 37 ).

Pela Tabela 41, pode-se observar que para as sementes do lote 3 , quando a disponibilidade hídrica foi menor, a ocorrência de sintomas por deterioração por "umidade" não diferiu durante as primeiras 18 horas de embebição sob potencial hídrico de $-0,40 \mathrm{MPa}$, para os três teores de água estudados. Além disso, a ocorrência de sintomas de deterioração por "umidade" das sementes que apresentavam-se com menor teor de água, $90 \mathrm{~g} / \mathrm{kg}$, não diferiu das mais úmidas (110 e $130 \mathrm{~g}$ de água $/ \mathrm{kg})$ sob o mesmo potencial hídrico de $-0,40 \mathrm{MPa}$. 
Tabela 39. Deterioração por "umidade" (TZ 1-5): valores médios (\%) obtidos para o lote 1 de sementes de soja do cultivar IAC-15, com teores de água ajustados, após exposição à combinação entre períodos de absorção de água e diferentes potenciais hídricos, e coeficiente de variação.

\begin{tabular}{|c|c|c|c|c|c|}
\hline \multirow{2}{*}{$\begin{array}{l}\text { Potenciais } \\
\text { Hidricos } \\
\mathrm{MPa}\end{array}$} & \multirow{2}{*}{$\begin{array}{c}\text { Periodos de } \\
\text { absorção } \\
\text { h }\end{array}$} & \multicolumn{3}{|c|}{ Teores de água ( $\mathrm{g} / \mathrm{kg}$ de sementes) } & \multirow[t]{2}{*}{ Médias } \\
\hline & & 90 & 110 & 130 & \\
\hline \multirow{6}{*}{$-0,04$} & 2 & 70 & 70 & 69 & $70 \mathrm{a}$ \\
\hline & 4 & 70 & 71 & 66 & $69 \mathrm{a}$ \\
\hline & 6 & 70 & 70 & 64 & $68 \mathrm{a}$ \\
\hline & 9 & 70 & 68 & 66 & $68 \mathrm{a}$ \\
\hline & 12 & 73 & 69 & 64 & $69 \mathrm{a}$ \\
\hline & 18 & 70 & 70 & 60 & $67 \mathrm{a}$ \\
\hline Médias & & $71 \mathrm{~B}$ & $70 \mathrm{AB}$ & $65 \mathrm{~A}$ & \\
\hline C.V. $(\%)$ & & 2.09 & & & \\
\hline \multirow{6}{*}{$-.0,10$} & 2 & $70 \mathrm{Babc}$ & $63 \mathrm{Aa}$ & $60 \mathrm{Aa}$ & 64 \\
\hline & 4 & $66 \mathrm{Ba}$ & $67 \mathrm{Bab}$ & $59 \mathrm{Aa}$ & 64 \\
\hline & 6 & $68 \mathrm{Aab}$ & $71 \mathrm{Ab}$ & $67 \mathrm{Ab}$ & 69 \\
\hline & 9 & $74 \mathrm{BC}$ & $68 \mathrm{Aab}$ & $65 \mathrm{Aab}$ & 69 \\
\hline & 12 & $72 \mathrm{Bbc}$ & $71 \mathrm{Bb}$ & $61 \mathrm{Aab}$ & 68 \\
\hline & 18 & $71 \mathrm{Babc}$ & $68 \mathrm{Bab}$ & $63 \mathrm{Aab}$ & 68 \\
\hline Médias & & 70 & 68 & 63 & \\
\hline C.V. $(\%)$ & & 2.06 & & & \\
\hline \multirow{6}{*}{-0.20} & 2 & $72 \mathrm{Ca}$ & $67 \mathrm{Bab}$ & $58 \mathrm{Aab}$ & 66 \\
\hline & 4 & $72 \mathrm{Ba}$ & $63 \mathrm{Aa}$ & $60 \mathrm{Aabc}$ & 65 \\
\hline & 6 & $67 \mathrm{Ba}$ & $69 \mathrm{Bab}$ & $59 \mathrm{Aab}$ & 65 \\
\hline & 9 & $70 \mathrm{Ba}$ & $70 \mathrm{Bb}$ & $64 \mathrm{Abc}$ & 68 \\
\hline & 12 & $69 \mathrm{Aa}$ & $69 \mathrm{Aab}$ & $66 \mathrm{Ac}$ & 68 \\
\hline & 18 & $72 \mathrm{Ba}$ & $68 \mathrm{Bab}$ & $57 \mathrm{Aa}$ & 66 \\
\hline Médias & & 70 & 67 & 61 & \\
\hline C.V. $(\%)$ & & 2.07 & & & \\
\hline \multirow{6}{*}{-0.40} & 2 & $66 \mathrm{Aa}$ & $67 \mathrm{Aabc}$ & $63 \mathrm{Aab}$ & 66 \\
\hline & 4 & $68 \mathrm{Ba}$ & $69 \mathrm{Bbc}$ & $61 \mathrm{Aab}$ & 66 \\
\hline & 6 & $67 \mathrm{Aa}$ & $63 \mathrm{Aab}$ & $67 \mathrm{Ab}$ & 66 \\
\hline & 9 & $72 \mathrm{Ba}$ & $63 \mathrm{Aa}$ & $60 \mathrm{Aa}$ & 65 \\
\hline & 12 & $71 \mathrm{Ba}$ & $70 \mathrm{Bc}$ & $60 \mathrm{Aa}$ & 67 \\
\hline & 18 & $70 \mathrm{Ba}$ & $69 \mathrm{Bbc}$ & $60 \mathrm{Aa}$ & 67 \\
\hline Médias & & 69 & 67 & 62 & \\
\hline C.V. $(\%)$ & & 2.10 & & & \\
\hline
\end{tabular}

Letras minusculas: comparaçōes entre médias dentro de cada coluna.

Letras maiúsculas: comparações entre médias dentro de cada linha 
Tabela 40. Deterioração por "umidade". (TZ 1-5): valores médios (\%) obtidos para o lote 2 de sementes de soja do cultivar IAC-15, com teores de água ajustados, após exposição à combinação entre períodos de absorção de água e diferentes potenciais hídricos, e coeficiente de variação.

\begin{tabular}{|c|c|c|c|c|c|}
\hline \multirow{2}{*}{$\begin{array}{c}\text { Potenciais } \\
\text { Hídricos } \\
\mathrm{MPa}\end{array}$} & \multirow{2}{*}{$\begin{array}{c}\text { Períodos de } \\
\text { absorção } \\
\text { h }\end{array}$} & \multicolumn{3}{|c|}{ Teores de água ( $\mathrm{g} / \mathrm{kg}$ de sementes) } & \multirow[t]{2}{*}{ Médias } \\
\hline & & 90 & 110 & 130 & \\
\hline \multirow{6}{*}{$-0,04$} & 2 & 77 & 71 & 73 & $73 \mathrm{a}$ \\
\hline & 4 & 78 & 74 & 73 & $75 \mathrm{a}$ \\
\hline & 6 & 76 & 75 & 74 & $75 \mathrm{a}$ \\
\hline & 9 & 72 & 76 & 71 & $73 \mathrm{a}$ \\
\hline & 12 & 74 & 74 & 74 & $74 \mathrm{a}$ \\
\hline & 18 & 72 & 74 & 73 & $73 \mathrm{a}$ \\
\hline Médias & & $75 \mathrm{~A}$ & $74 \mathrm{~A}$ & $73 \mathrm{~A}$ & \\
\hline C.V. $(\%)$ & & 2.44 & & & \\
\hline \multirow{6}{*}{$-.0,10$} & 2 & 78 & 72 & 71 & 74 a \\
\hline & 4 & 77 & 74 & 71 & $74 \mathrm{a}$ \\
\hline & 6 & 76 & 70 & 73 & $73 \mathrm{a}$ \\
\hline & 9 & 74 & 69 & 70 & $71 \mathrm{a}$ \\
\hline & 12 & 74 & 74 & 66 & $71 \mathrm{a}$ \\
\hline & 18 & 74 & 72 & 72 & $73 \mathrm{a}$ \\
\hline Médias & & $76 \mathrm{~B}$ & $72 \mathrm{~A}$ & $71 \mathrm{~A}$ & \\
\hline C.V. $(\%)$ & & 2.26 & & & \\
\hline \multirow{6}{*}{$-0,20$} & 2 & 72 & 70 & 72 & $71 \mathrm{a}$ \\
\hline & 4 & 71 & 72 & 71 & $71 \mathrm{a}$ \\
\hline & 6 & 74 & 73 & 71 & $73 \mathrm{a}$ \\
\hline & 9 & 74 & 69 & 71 & $71 \mathrm{a}$ \\
\hline & 12 & 76 & 71 & 71 & $73 \mathrm{a}$ \\
\hline & 18 & 72 & 74 & 69 & $72 \mathrm{a}$ \\
\hline Médias & & $73 \mathrm{~B}$ & $72 \mathrm{AB}$ & $71 \mathrm{~A}$ & \\
\hline C.V. $(\%)$ & & 1.96 & & & \\
\hline \multirow{6}{*}{$-0,40$} & 2 & $71 \mathrm{Aab}$ & $73 \mathrm{ABab}$ & $76 \mathrm{Bb}$ & 73 \\
\hline & 4 & $70 \mathrm{Aa}$ & $78 \mathrm{Bb}$ & $71 \mathrm{Aab}$ & 73 \\
\hline & 6 & $73 \mathrm{Aab}$ & $73 \mathrm{Aab}$ & $72 \mathrm{Aab}$ & 73 \\
\hline & 9 & $71 \mathrm{ABab}$ & $68 \mathrm{Aa}$ & $73 \mathrm{Bab}$ & 71 \\
\hline & 12 & $76 \mathrm{Bb}$ & $72 \mathrm{ABa}$ & $70 \mathrm{Aa}$ & 73 \\
\hline & 18 & $73 \mathrm{Aab}$ & $69 \mathrm{Aba}$ & $72 \mathrm{Aab}$ & 71 \\
\hline Médias & & 72 & 72 & 72 & \\
\hline C.V. $(\%)$ & & 2.14 & & & \\
\hline
\end{tabular}

Letras minúsculas: comparações entre médias dentro de cada coluna.

Letras maiúsculas: comparações entre médias dentro de cada linha. 
Tabela 41. Deterioração por "umidade" (TZ 1-5): valores médios (\%) obtidos para o lote 3 de sementes de soja do cultivar IAC-15, com teores de água ajustados, após exposição à combinação entre períodos de absorção de água e diferentes potenciais hídricos, e coeficiente de variação.

\begin{tabular}{|c|c|c|c|c|c|}
\hline \multirow{2}{*}{$\begin{array}{c}\text { Potenciais } \\
\text { Hidricos } \\
\mathrm{MPa}\end{array}$} & \multirow{2}{*}{$\begin{array}{c}\text { Períodos de } \\
\text { absorção } \\
\text { h }\end{array}$} & \multicolumn{3}{|c|}{ Teores de água ( $\mathrm{g} / \mathrm{kg}$ de sementes) } & \multirow[t]{2}{*}{ Médias } \\
\hline & & 90 & 110 & 130 & \\
\hline & 2 & 78 & 80 & 80 & $80 \mathrm{a}$ \\
\hline \multirow[t]{5}{*}{$-0,04$} & 4 & 77 & 79 & 80 & $78 \mathrm{a}$ \\
\hline & 6 & 79 & 78 & 80 & $79 a$ \\
\hline & 9 & 80 & 80 & 76 & 79 a \\
\hline & 12 & 76 & 77 & 79 & $77 \mathrm{a}$ \\
\hline & 18 & 79 & 76 & 76 & $77 \mathrm{a}$ \\
\hline Médias & & $78 \mathrm{~A}$ & $78 \mathrm{~A}$ & $79 \mathrm{~A}$ & \\
\hline C.V. $(\%)$ & & 2.72 & & & \\
\hline \multirow{6}{*}{$-0,10$} & 2 & $80 \mathrm{Aa}$ & $79 \mathrm{Ab}$ & $77 \mathrm{Aa}$ & 79 \\
\hline & 4 & $78 \mathrm{Aa}$ & $76 \mathrm{Aab}$ & $79 \mathrm{Aa}$ & 78 \\
\hline & 6 & $80 \mathrm{Aa}$ & $77 \mathrm{Aab}$ & $77 \mathrm{Aa}$ & 78 \\
\hline & 9 & $76 \mathrm{ABa}$ & $72 \mathrm{Aa}$ & $78 \mathrm{Ba}$ & 75 \\
\hline & 12 & $77 \mathrm{Aa}$ & $78 \mathrm{Ab}$ & $75 \mathrm{Aa}$ & 77 \\
\hline & 18 & $78 \mathrm{Aa}$ & $75 \mathrm{Aab}$ & $77 \mathrm{Aa}$ & 77 \\
\hline Médias & & 79 & 76 & 77 & \\
\hline C.V. $(\%)$ & & 1.69 & & & \\
\hline \multirow{6}{*}{$-0,20$} & 2 & 77 & 77. & 80 & $78 \mathrm{~b}$ \\
\hline & 4 & 72 & 73 & 75 & $73 \mathrm{ab}$ \\
\hline & 6 & 75 & 75 & 77 & $76 \mathrm{ab}$ \\
\hline & 9 & 77 & 76 & 75 & $76 \mathrm{ab}$ \\
\hline & 12 & 75 & 74 & 74 & $74 \mathrm{a}$ \\
\hline & 18 & 77 & 76 & 77 & $77 \mathrm{ab}$ \\
\hline Médias & & $76 \mathrm{~A}$ & $75 \mathrm{~A}$ & $76 \mathrm{~A}$ & \\
\hline C.V. $(\%)$ & & 2.06 & & & \\
\hline \multirow{6}{*}{-0.40} & 2 & 75 & 77 & 79 & $77 a$ \\
\hline & 4 & 77 & 77 & 73 & $76 a$ \\
\hline & 6 & 74 & 75 & 74 & $74 a$ \\
\hline & 9 & 73 & 74 & 76 & $74 \mathrm{a}$ \\
\hline & 12 & 75 & 77 & 76 & $76 \mathrm{a}$ \\
\hline & 18 & 76 & 75 & 75 & $75 \mathrm{a}$ \\
\hline Médias & & $75 \mathrm{~A}$ & $76 \mathrm{~A}$ & $76 \mathrm{~A}$ & \\
\hline C.V. $(\%)$ & & 2.08 & & & \\
\hline
\end{tabular}

Letras minúsculas: comparaçōes entre médias dentro de cada coluna.

Letras maiusculas: comparações entre médias dentro de cada linha. 
Em termos numéricos, quando compararam-se os 3 lotes, observou-se que a ocorrência de sintomas de deterioração por "umidade" foi ligeiramente acentuada nos lotes 2 e 3 , de qualidade fisiológica inferior ao lote 1 , durante as primeiras 18 horas sob diferentes potenciais hídricos do substrato (Tabelas 39 a 41). Tal observação, também, foi constatada por ocasião das determinações para caracterizaçcão dos lotes. Desta forma, após 18 horas de embebição, igualou-se todos os tratamentos de hidratação.

4.4. Relações entre o teor de água e a germinação das sementes sob a influência de diferentes potenciais hídricos

Nas Tabelas 42 a 44, onde estão apresentados os resultados das análises da variância dos dados referentes aos testes para avaliação das relações entre o teor de água e a germinação de sementes, observaram-se valores de $\mathrm{F}$ altamente significativos para os efeitos de Potenciais hídricos sobre germinação e ocorrência de plântulas anormais na avaliação realizada com os 3 lotes e, sobre a emissão de raiz primária e ocorrência de plântulas normais na primeira contagem do teste de germinação na avaliação realizada com os lotes 2 e 3 . Observaram-se, também, valores de F significativos para os efeitos de Teores de água sobre a germinação na avaliação realizada com os lotes 1 e 2 e sobre a ocorrência de plântulas anormais do teste de germinação na avaliação realizada com o lote 1 . 
Tabela 42. Valores de F obtidos nas análises da variância dos dados referentes ao estudo das relações entre o teor de água e germinação das sementes do lote 1 sob a influència de diferentes potenciais hídricos do substrato.

\begin{tabular}{lcccc}
\hline Causas da Variação & $\begin{array}{c}\text { Emissão de raiz } \\
\text { primária } \\
(\%)\end{array}$ & $\begin{array}{c}\text { Germinação } \\
(\%)\end{array}$ & $\begin{array}{c}\text { Plântulas } \\
\text { Anormais } \\
(\%)\end{array}$ & $\begin{array}{c}\text { Primeira } \\
\text { Contagem } \\
(\%)\end{array}$ \\
\hline Potenciais (H) & $90.7521^{* *}$ & $277.8242^{* *}$ & $267.7427^{* *}$ & $287.8832^{* *}$ \\
Teores de água (A) & $0.1654^{\text {ns }}$ & $5.4250^{* *}$ & $3.4163^{*}$ & $0.4076^{\text {ns }}$ \\
HX A & $2.7834^{*}$ & $0.7512^{\mathrm{ns}}$ & $0.5389^{\mathrm{ns}}$ & $2.7600^{*}$ \\
\hline
\end{tabular}

* significativo ao nivel de $5 \%$ de probabilidade; ${ }^{* *}$ significativo ao nível de $1 \%$ de probabilidade ns não significativo

Tabela 43. Valores de F obtidos nas análises da variância dos dados referentes ao estudo das relações entre o teor de água e germinação das sementes do lote 2 sob a influência de diferentes potenciais hídricos do substrato.

\begin{tabular}{lcccc}
\hline Causas da Variação & $\begin{array}{c}\text { Emissão de raiz } \\
\text { primária } \\
(\%)\end{array}$ & $\begin{array}{c}\text { Germinação } \\
(\%)\end{array}$ & $\begin{array}{c}\text { Plântulas } \\
\text { Anormais } \\
(\%)\end{array}$ & $\begin{array}{c}\text { Primeira } \\
\text { Contagem } \\
(\%)\end{array}$ \\
\hline Potenciais (H) & $86.0944^{* *}$ & $176.9501^{* *}$ & $101.0706^{* *}$ & $123.4899^{* *}$ \\
Teores de água (A) & $0.9067^{\mathrm{ns}}$ & $3.2841^{*}$ & $1.8189^{\mathrm{ns}}$ & $0.4665^{\mathrm{ns}}$ \\
HX A & $1.0169^{\mathrm{ns}}$ & $0.7793^{\mathrm{ns}}$ & $0.7825^{\mathrm{ns}}$ & $0.3943^{\mathrm{ns}}$ \\
\hline
\end{tabular}

* significativo ao nivel de $5 \%$ de probabilidade; ${ }^{* *}$ significativo ao nivel de $1 \%$ de probabilidade ns não significativo 
Tabela 44. Valores de F obtidos nas análises da variância dos dados referentes ao estudo das relações entre o teor de água e germinação das sementes do lote 3 sob a influência de diferentes potenciais hídricos do substrato.

\begin{tabular}{|c|c|c|c|c|}
\hline Causas da Variação & $\begin{array}{c}\text { Emissão de raiz } \\
\text { primária } \\
(\%) \\
\end{array}$ & $\begin{array}{c}\text { Germinação } \\
(\%) \\
\end{array}$ & $\begin{array}{c}\text { Plântulas } \\
\text { Anormais } \\
(\%)\end{array}$ & $\begin{array}{c}\text { Primeira } \\
\text { Contagem } \\
(\%) \\
\end{array}$ \\
\hline Potenciais $(\mathrm{H})$ & $85.6312^{* *}$ & $132.4512^{* *}$ & $78.1966^{* *}$ & $216.8445^{* *}$ \\
\hline Teores de água (A) & $1.9981^{\mathrm{nS}}$ & $2.9507^{\mathrm{ns}}$ & $0.1286^{\mathrm{ns}}$ & $2.7210^{\mathrm{ns}}$ \\
\hline $\mathrm{HXA}$ & $0.7043^{\mathrm{ns}}$ & $1.2393^{\mathrm{ns}}$ & $0.2911^{\mathrm{ns}}$ & $1.9111^{\mathrm{nS}}$ \\
\hline
\end{tabular}

${ }^{*}$ significativo ao nivel de $5 \%$ de probabilidade; ${ }^{* *}$ significativo ao nível de $1 \%$ de probabilidade ns não significativo

Pela Tabela 45, pode-se constatar que houve uma redução mais acentuada da emissão de raiz primária nas sementes do lote 1 , que apresentavam-se com $110 \mathrm{~g}$ de água/kg sob a influência do potencial hídrico de -0,40 MPa. Notou-se que, por ocasião da avaliação da emissão da raiz primária das sementes do lote 1 após 3 dias da instalação do teste de germinação, praticamente todas as sementes já tinham emitido a raiz primária sob os potenciais hídricos de $-0,04$ e $-0,10 \mathrm{MPa}$, concordando com as informações da Figura 8, onde essa emissão ocorreu após 36 e 42 horas de embebição, respectivamente, para os potenciais hídricos citados, caracterizando o início da fase III descrita por BEWLEY \& BLACK (1985). 
Tabela 45. Emissão de raiz primária: valores médios (\%) obtidos para o lote 1 de sementes de soja do cultivar IAC-15, com teores de água ajustados, após exposição a diferentes potenciais hídricos, e coeficiente de variação.

\begin{tabular}{ccccc}
\hline Potenciais hídricos $(\mathrm{MPa})$ & \multicolumn{3}{c}{ Teores de água $(\mathrm{g} / \mathrm{kg}$ de sementes) } & \multirow{2}{*}{ Médias } \\
\cline { 2 - 4 } & 90 & 110 & 130 & 100 \\
$-0,04$ & $100 \mathrm{Aa}$ & $100 \mathrm{Aa}$ & $100 \mathrm{Aa}$ & 98 \\
$-0,10$ & $99 \mathrm{Aab}$ & $98 \mathrm{Aa}$ & $98 \mathrm{Aab}$ & 95 \\
$-0,20$ & $95 \mathrm{Ab}$ & $98 \mathrm{Aa}$ & $93 \mathrm{Ab}$ & 67 \\
$-0,40$ & $63 \mathrm{ABc}$ & $59 \mathrm{Bb}$ & $78 \mathrm{Ac}$ & \\
\hline Médias & 90 & 89 & 92 & \\
\hline C.V. $(\%)$ & 7.3 & & & \\
\hline
\end{tabular}

Letras minúsculas: comparações entre médias dentro de cada coluna.

Letras maiúsculas: comparações entre médias dentro de cada linha.

A emissão da raiz primária das sementes dos lotes 2 e 3 foi diminuindo à medida em que foi reduzido o potencial hídrico, para os três teores de água estudados. No entanto, a emissão de raiz primária não diferiu sob os potenciais hídricos de $-0,04 \mathrm{e}$ $0,10 \mathrm{MPa}$ (Tabelas 46 e 47).

Pelas Tabelas 46 e 47, também. nota-se que por ocasião da avaliação da emissão da raiz primária das sementes dos lotes 2 e 3 , após 3 dias da instalação do teste de germinação, praticamente todas as sementes já tinham emitido a raiz primária sob os potenciais hídricos de $-0,04$ e $-0,10 \mathrm{MPa}$, à semelhança do observado para o lote 1 e de acordo com as informações das Figuras 10 e 12, onde esta emissão ocorreu após 36 e 42 horas de embebição, respectivamente, para os potenciais hídricos citados (Tabelas $46 \mathrm{e}$ 47).

Em relação ao teor de água das sementes, verificou-se que a emissão de raiz primária das sementes dos lotes 2 e 3 . com menor teor de água $(90 \mathrm{~g} / \mathrm{kg})$, não diferiu da observada para as sementes com 110 e $130 \mathrm{~g}$ de água $/ \mathrm{kg}$. Assim, a menor velocidade de absorção de água não interferiu na emissão de raiz primária (Tabelas 46 e 47). 
Tabela 46. Emissão de raiz primária: valores médios (\%) obtidos para o lote 2 de sementes de soja do cultivar IAC-15, com teores de água ajustados, após exposição a diferentes potenciais hídricos, e coeficiente de variação.

\begin{tabular}{|c|c|c|c|c|}
\hline \multirow[t]{2}{*}{ Potenciais hidricos $(\mathrm{MPa})$} & \multicolumn{3}{|c|}{ Teores de água ( $\mathrm{g} / \mathrm{kg}$ de sementes) } & \multirow[b]{2}{*}{ Médias } \\
\hline & 90 & 110 & 130 & \\
\hline$-0,04$ & 97 & 100 & 96 & $98 \mathrm{a}$ \\
\hline$-0,10$ & 95 & 95 & 98 & $96 \mathrm{a}$ \\
\hline$-0,20$ & 84 & 89 & 87 & $86 \mathrm{~b}$ \\
\hline$-0,40$ & 47 & 47 & 39 & $44 \mathrm{c}$ \\
\hline Médias & $80 \mathrm{~A}$ & $83 \mathrm{~A}$ & $80 \mathrm{~A}$ & \\
\hline C.V. $(\%)$ & 10.5 & & & \\
\hline
\end{tabular}

Letras minúsculas: comparações entre médias dentro de cada coluna.

Letras maiúsculas: comparações entre médias dentro de cada linha.

Tabela 47. Emissão de raiz primária: valores médios (\%) obtidos para o lote 3 de sementes de soja do cultivar IAC-15, com teores de água ajustados, após exposição a diferentes potenciais hídricos, e coeficiente de variação.

\begin{tabular}{ccccc}
\hline Potenciais hídricos $(\mathrm{MPa})$ & \multicolumn{3}{c}{ Teores de água $(\mathrm{g} / \mathrm{kg}$ de sementes) } & Médias \\
\cline { 2 - 5 } & 90 & 110 & 130 & $94 \mathrm{a}$ \\
$-0,04$ & 94 & 97 & 92 & $95 \mathrm{a}$ \\
$-0,10$ & 95 & 95 & 96 & $74 \mathrm{~b}$ \\
$-0,20$ & 67 & 74 & 81 & $47 \mathrm{c}$ \\
$-0,40$ & 45 & 52 & 45 & \\
\hline Médias & $75 \mathrm{~A}$ & $80 \mathrm{~A}$ & $79 \mathrm{~A}$ & \\
\hline C.V. $(\%)$ & 9.8 & & & \\
\hline
\end{tabular}

Letras minúsculas: comparaçōes entre médias dentro de cada coluna.

Letras maiúsculas: comparações entre médias dentro de cada linha. 
A germinação das sementes dos três lotes foi afetada significativamente pelo potencial hídrico do substrato (Tabelas 48 a 50). Assim, à medida em que foi reduzido o potencial hídrico do substrato, ocorreu uma diminuição na germinação das sementes do lote 1, para os três teores de água estudados. No entanto, sob potencial hídrico de -0,04 e -0,10 MPa, a germinação das sementes do lote 1 não diferiu entre si.

Em relação ao teor de água das sementes, pode-se constatar que a germinação das sementes do lote 1 , com menor teor de água $(90 \mathrm{~g} / \mathrm{kg})$, foi mais prejudicada que a das sementes com 110 e $130 \mathrm{~g}$ de água $/ \mathrm{kg}$, sob os diferentes potenciais hídricos (Tabela 48). Além disso, as sementes do lote 1 , com menor teor de água $(90 \mathrm{~g} / \mathrm{kg})$, apresentaram danos por embebição mais intensos, avaliados tanto através da liberação de íons na solução como pela ocorrência de sintomas de deterioração por "umidade" sob todos os potenciais hídricos, principalmente, sob o potencial hídrico de $0,04 \mathrm{MPa}$. Desta forma, pode-se constatar que o aumento do teor de água diminuiu os danos por embebição, avaliados tanto pela liberação de íons como pela ocorrência de sintomas de deterioração por umidade e favoreceu a germinação das sementes principalmente sob o potencial hídrico de -0,04 MPa.

Pelas Tabelas 49 e 50 , pode-se constatar que à medida em que foi reduzido o potencial hídrico, ocorreu uma diminuição na germinação das sementes dos lotes 2 e 3, para os três teores de água estudados à semelhança do observado para o lote 1, provavelmente, devido a uma redução crítica da quantidade de água necessária para o desenvolvimento das plântulas. No entanto, sob potencial hídrico de $-0,04$ e $-0,10 \mathrm{MPa}$, a germinação dessas sementes não diferiu, à semelhança do observado para as sementes do lote 1. Para SÁ (1987), à medida em que se reduziu o potencial hídrico, ocorreu uma significativa diminuição da germinação das sementes, principalmente, para o potencial hídrico de $-0,6 \mathrm{MPa}$. 
Tabela 48. Germinação: valores médios (\%) obtidos para o lote 1 de sementes de soja do cultivar IAC-15, com teores de água ajustados, após exposição a diferentes potenciais hídricos, e coeficiente de variação.

\begin{tabular}{ccccc}
\hline Potenciais hídricos $(\mathrm{MPa})$ & \multicolumn{3}{c}{ Teores de água $(\mathrm{g} / \mathrm{kg}$ de sementes) } & \multirow{2}{*}{ Médias } \\
\cline { 2 - 5 } & 90 & 110 & 130 & $86 \mathrm{a}$ \\
\hline$-0,04$ & 83 & 88 & 87 & $82 \mathrm{a}$ \\
$-0,10$ & 81 & 81 & 83 & $58 \mathrm{~b}$ \\
$-0,20$ & 51 & 63 & 60 & $30 \mathrm{c}$ \\
$-0,40$ & 27 & 32 & 31 & \\
\hline Médias & $61 \mathrm{~B}$ & $66 \mathrm{~A}$ & $65 \mathrm{~A}$ & \\
\hline C.V. $(\%)$ & 6.2 & & & \\
\hline
\end{tabular}

Letras minúsculas: comparações entre médias dentro de cada coluna.

Letras maiúsculas: comparações entre médias dentro de cada linha.

Em relação ao teor de água das sementes, pode-se constatar que a germinação das sementes do lote 2 , com menor teor de água $(90 \mathrm{~g} / \mathrm{kg})$, não diferiu da germinação das sementes com 110 e $130 \mathrm{~g}$ de água $/ \mathrm{kg}$ sob os diferentes potenciais hídricos (Tabela 49). No entanto, verificaram-se valores de $\mathrm{F}$ significativos para os teores de água sobre a germinação dessas sementes (Tabela 43). Além disso, quando avaliaramse os danos por embebição do lote 2, as sementes com menor teor de água apresentaram intensa liberação de ions, principalmente sob os potenciais hídricos de $-0,04$ e $-0,10 \mathrm{MPa}$, e maior ocorrência de sintomas de deterioração por "umidade" sob os potenciais de $-0,10$ e -0,20 MPa. Desta forma, o aumento do teor de água diminuiu os danos por embebição avaliados pela liberação de ions, principalmente sob os potenciais hídricos de $-0,04 \mathrm{e}$ $0,10 \mathrm{MPa}$ e tendeu a favorecer a germinação das sementes. 
Tabela 49. Germinação: valores médios (\%) obtidos para o lote 2 de sementes de soja do cultivar IAC-15, com teores de água ajustados, após exposição a diferentes potenciais hídricos, e coeficiente de variação.

\begin{tabular}{|c|c|c|c|c|}
\hline \multirow[t]{2}{*}{ Potenciais hídricos (MPa) } & \multicolumn{3}{|c|}{ Teores de água ( $g / \mathrm{kg}$ de sementes) } & \multirow[b]{2}{*}{ Médias } \\
\hline & 90 & 110 & 130 & \\
\hline$-0,04$ & 77 & 77 & 78 & $77 \mathrm{a}$ \\
\hline$-0,10$ & 71 & 67 & 79 & $73 \mathrm{a}$ \\
\hline$-0,20$ & 53 & 54 & 61 & $56 \mathrm{~b}$ \\
\hline$-0,40$ & 19 & 21 & 22 & $20 \mathrm{c}$ \\
\hline Médias & $55 \mathrm{~A}$ & $55 \mathrm{~A}$ & $60 \mathrm{~A}$ & \\
\hline C.V. $(\%)$ & 8.4 & & & \\
\hline
\end{tabular}

Letras minúsculas: comparações entre médias dentro de cada coluna.

Letras maiúsculas: comparações entre médias dentro de cada linha.

Tabela 50. Germinação: valores médios (\%) obtidos para o lote 3 de sementes de soja do cultivar IAC-15, com teores de água ajustados, após exposição a diferentes potenciais hídricos, e coeficiente de variação.

\begin{tabular}{ccccc}
\hline Potenciais hidricos (MPa) & \multicolumn{2}{c}{ Teores de agua $(\mathrm{g} / \mathrm{kg}$ de sementes) } & \\
\cline { 2 - 4 } & 90 & 110 & 130 & Médias \\
\hline$-0,04$ & 64 & 67 & 68 & $66 \mathrm{a}$ \\
$-0,10$ & 67 & 64 & 69 & $67 \mathrm{a}$ \\
$-0,20$ & 33 & 40 & 48 & $40 \mathrm{~b}$ \\
$-0,40$ & 24 & 24 & 24 & $24 \mathrm{c}$ \\
\hline Médias & $47 \mathrm{~A}$ & $49 \mathrm{~A}$ & $52 \mathrm{~A}$ & \\
\hline C.V. $\%)$ & 8.4 & & & \\
\hline
\end{tabular}

Letras minúsculas: comparações entre médias dentro de cada coluna.

Letras maiúsculas: comparações entre médias dentro de cada linha. 
$\mathrm{Na}$ Tabela 50, pode-se constatar que a germinação das sementes do lote 3 , com menor teor de água $(90 \mathrm{~g} / \mathrm{kg})$, não diferiu da germinação das sementes com $110 \mathrm{e}$ $130 \mathrm{~g}$ de água $/ \mathrm{kg}$ sob os diferentes potenciais hídricos, à semelhança do constatado para o lote 2. Além disso, quando avaliaram-se os danos por embebição do lote 3, observou-se que as sementes com menor teor de água $(90 \mathrm{~g} / \mathrm{kg})$ apresentaram intensa liberação de íons sob os potenciais hídricos de $-0,10 ;-0,20$ e -0,40 MPa e, não diferiram das mais úmidas (110 e $130 \mathrm{~g}$ de água $/ \mathrm{kg}$ ) quanto à ocorrência de sintomas de deterioração por "umidade". Porém, estes danos, avaliados pela liberação de íons, não interferiram na viabilidade.

Constata-se pelas Tabelas 51 a 53 , que à medida em que foi reduzido o potencial hídrico, houve acréscimos de plântulas anormais provenientes dos lotes $1,2 \mathrm{e}$ 3 , para os três teores de água estudados. No entanto, sob potencial hídrico de $-0,04$ e $-0,10 \mathrm{MPa}$, a ocorrência de plântulas anormais não diferiu. Além disso, o aumento do teor de água das sementes dos três lotes não diminuiu a ocorrência de plântulas anormais, porém, verificaram-se valores de $\mathrm{F}$ significativos para efeitos dos teores de água sobre a ocorrência de plântulas anormais provenientes das sementes do lote 1 .

$\mathrm{O}$ aumento de plântulas anormais infeccionadas foi devido ao crescimento de patógenos, principalmente, para as condições de menor potencial hídrico do substrato, ou seja, de hidratação lenta, que favoreceram a maior exsudação de íons pelas sementes; resultados semelhantes foram obtidos por PEREIRA et al. (1981). Neste caso, o tratamento prévio das sementes com fungicidas não foi eficiente. 
Tabela 51. Plântulas Anormais: valores médios (\%) obtidos para o lote 1 de sementes de soja do cultivar IAC-15, com teores de água ajustados, após exposição a diferentes potenciais hídricos, e coeficiente de variação.

\begin{tabular}{|c|c|c|c|c|}
\hline \multirow[t]{2}{*}{ Potenciais hídricos $(\mathrm{MPa})$} & \multicolumn{3}{|c|}{ Teores de água ( $\mathrm{g} / \mathrm{kg}$ de sementes) } & \multirow[b]{2}{*}{ Médias } \\
\hline & 90 & 110 & 130 & \\
\hline$-0,04$ & 14 & 11 & 11 & $12 c$ \\
\hline$-0,10$ & 16 & 16 & 15 & $16 \mathrm{c}$ \\
\hline$-0,20$ & 46 & 36 & 38 & $40 \mathrm{~b}$ \\
\hline$-0,40$ & 68 & 64 & 64 & $65 \mathrm{a}$ \\
\hline Médias & $36 \mathrm{~A}$ & $32 \mathrm{~A}$ & $32 \mathrm{~A}$ & \\
\hline C.V. $(\%)$ & 9.7 & & & \\
\hline
\end{tabular}

Letras minúsculas: comparações entre médias dentro de cada coluna.

Letras maiúsculas: comparações entre médias dentro de cada linha.

Tabela 52. Plântulas Anormais: valores médios (\%) obtidos para o lote 2 de sementes de soja do cultivar IAC-15, com teores de água ajustados, após exposição a diferentes potenciais hídricos, e coeficiente de variação.

\begin{tabular}{ccccc}
\hline Potenciais hidricos $(\mathrm{MPa})$ & \multicolumn{2}{c}{ Teores de água $(\mathrm{g} / \mathrm{kg}$ de sementes $)$} & \\
\cline { 2 - 4 } & 90 & 110 & 130 & Médias \\
\hline$-0,04$ & 19 & 19 & 18 & $19 \mathrm{c}$ \\
$-0,10$ & 24 & 29 & 18 & $24 \mathrm{c}$ \\
$-0,20$ & 40 & 41 & 34 & $38 \mathrm{~b}$ \\
$-0,40$ & 64 & 69 & 69 & $67 \mathrm{a}$ \\
\hline Médias & $37 \mathrm{~A}$ & $40 \mathrm{~A}$ & $35 \mathrm{~A}$ & \\
\hline C.V. $(\%)$ & 12.4 & & & \\
\hline
\end{tabular}

Letras minusculas: comparações entre médias dentro de cada coluna.

Letras maiusculas: comparações entre médias dentro de cada linha. 
Tabela 53. Plântulas Anormais: valores médios (\%) obtidos para o lote 3 de sementes de soja do cultivar IAC-15, com teores de água ajustados, após exposição a diferentes potenciais hídricos, e coeficiente de variação.

\begin{tabular}{|c|c|c|c|c|}
\hline \multirow[t]{2}{*}{ Potenciais hídricos $(\mathrm{MPa})$} & \multicolumn{3}{|c|}{ Teores de água ( $\mathrm{g} / \mathrm{kg}$ de sementes) } & \multirow[b]{2}{*}{ Médias } \\
\hline & 90 & 110 & 130 & \\
\hline$-0,04$ & 26 & 25 & 25 & $25 \mathrm{c}$ \\
\hline$-0,10$ & 24 & 25 & 25 & $25 \mathrm{c}$ \\
\hline$-0,20$ & 51 & 46 & 45 & $47 \mathrm{~b}$ \\
\hline$-0,40$ & 61 & 61 & 63 & $62 \mathrm{a}$ \\
\hline Médias & $41 \mathrm{~A}$ & $39 \mathrm{~A}$ & $40 \mathrm{~A}$ & \\
\hline C.V. $(\%)$ & 10.9 & & & \\
\hline
\end{tabular}

Letras minúsculas: comparações entre médias dentro de cada coluna.

Letras maiúsculas: comparações entre médias dentro de cada linha.

À medida em que foi reduzido o potencial hídrico, houve uma diminuição do vigor, avaliado na primeira contagem do teste de germinação, para os três teores de água estudados (Tabelas 54 a 56), concordando com SÁ (1987) que, também, constatou que houve prejuizo ao desempenho das sementes, avaliado através da primeira contagem do teste de germinação, à medida em que foi reduzido o potencial hídrico do substrato.

Nas Tabelas 55 e 56, também, pode-se constatar que o aumento do teor de água das sementes dos lotes 2 e 3 não favorecea ocorrência de plântulas normais por ocasião da primeira contagem do teste de germinação. Para o lote 1 , o aumento do teor de água, também, não favoreceu o vigor, com exceção sob o potencial hídrico de $-0,10$ MPa (Tabela 54). 
Tabela 54. Primeira contagem do teste de germinação: valores médios (\%) obtidos para o lote 1 de sementes de soja do cultivar IAC-15, com teores de água ajustados, após exposição a diferentes potenciais hídricos, e coeficiente de variação.

\begin{tabular}{clccc}
\hline Potenciais hídricos $(\mathrm{MPa})$ & \multicolumn{3}{c}{ Teores de água $(\mathrm{g} / \mathrm{kg}$ de sementes) } & \multirow{2}{*}{ Médias } \\
\cline { 2 - 4 } & 90 & 110 & 130 & 80 \\
\hline$-0,04$ & $75 \mathrm{Aa}$ & $82 \mathrm{Aa}$ & $82 \mathrm{Aa}$ & 69 \\
$-0,10$ & $75 \mathrm{Aa}$ & $63 \mathrm{Bb}$ & $69 \mathrm{ABb}$ & 69 \\
$-0,20$ & $48 \mathrm{Ab}$ & $49 \mathrm{Ac}$ & $50 \mathrm{Ac}$ & 49 \\
$-0,40$ & $21 \mathrm{Ac}$ & $21 \mathrm{Ad}$ & $21 \mathrm{Ad}$ & 21 \\
\hline Médias & 55 & 54 & 56 & \\
\hline C.V. (\%) & 6.7 & & & \\
\hline
\end{tabular}

Letras minúsculas: comparações entre médias dentro de cada coluna.

Letras maiúsculas: comparações entre médias dentro de cada linha

Tabela 55. Primeira contagem do teste de germinação: valores médios (\%) obtidos para o lote 2 de sementes de soja do cultivar IAC-15, com teores de água ajustados, após exposição a diferentes potenciais hídricos, e coeficiente de variação.

\begin{tabular}{ccccc}
\hline Potenciais hidricos (MPa) & \multicolumn{3}{c}{ Teores de agua $(\mathrm{g} / \mathrm{kg}$ de sementes) } & Médias \\
\cline { 2 - 5 } & 90 & 110 & 130 & $73 \mathrm{a}$ \\
\hline-0.04 & 75 & 72 & 72 & $60 \mathrm{~b}$ \\
$-0,10$ & 57 & 59 & 65 & $40 \mathrm{c}$ \\
$-0,20$ & 40 & 38 & 43 & $11 \mathrm{~d}$ \\
$-0,40$ & 13 & 10 & 11 & \\
\hline Médias & $46 \mathrm{~A}$ & $45 \mathrm{~A}$ & $48 \mathrm{~A}$ & \\
\hline C.V. $(\%)$ & 12.8 & & \\
\hline
\end{tabular}

Letras minúsculas: comparações entre médias dentro de cada coluna.

Letras maiúsculas: comparações entre médias dentro de cada linha. 
Tabela 56. Primeira contagem do teste de germinação: valores médios (\%) obtidos para o lote 3 de sementes de soja do cultivar IAC-15, com teores de água ajustados, após exposição a diferentes potenciais hídricos, e coeficiente de variação.

\begin{tabular}{ccccc}
\hline Potenciais hídricos $(\mathrm{MPa})$ & \multicolumn{3}{c}{ Teores de água $(\mathrm{g} / \mathrm{kg}$ de sementes) } & \\
\cline { 2 - 4 } & \multicolumn{9}{c}{90} & 110 & 130 & Médias \\
\hline$-0,04$ & 59 & 60 & 57 & $59 \mathrm{a}$ \\
$-0,10$ & 58 & 57 & 63 & $59 \mathrm{a}$ \\
$-0,20$ & 26 & 36 & 37 & $33 \mathrm{~b}$ \\
$-0,40$ & 10 & 7 & 13 & $10 \mathrm{c}$ \\
\hline Médias & $38 \mathrm{~A}$ & $40 \mathrm{~A}$ & $43 \mathrm{~A}$ & \\
\hline C.V. $(\%)$ & 9.4 & & & \\
\hline
\end{tabular}

Letras minúsculas: comparações entre médias dentro de cada coluna.

Letras maiúsculas: comparações entre médias dentro de cada linha.

Comparando-se os dados de vigor (primeira contagem) das sementes dos três lotes (Tabelas 54 a 56) com a porcentagem de emissão de raiz primária das sementes dos três lotes após 3 dias da instalação do teste de germinação (Tabelas 45 a 47), para os três teores de água estudados, constatou-se que as sementes, embora tivessem atingido o teor mínimo de água requerido para o início da fase III, ou seja, para a emissão da raiz primária como constatado nas Tabelas 45 a 47, apresentaram o desenvolvimento das plântulas prejudicado como constatado nas Tabelas 54 a 56, principalmente, sob condição de menor potencial hídrico, pois à medida em que aumentou-se a restrição hídrica através da maior concentração de polietilenoglicol (PEG), ocorreu aumento da viscosidade do meio e redução da velocidade de absorção de água das sementes, concordando com as informações relatadas por VERTUCCI (1989); consequentemente, ocorreu uma redução da velocidade dos processos fisiológicos e bioquímicos, de tal forma que, as plântulas apresentaram-se com menor desenvolvimento, fato também constatado por SÁ (1987). Além disso, esses dados mostram que a necessidade de água é maior na fase III 


\subsection{Relações entre o teor de água e emergência de plântulas sob a influência de diferentes potenciais hídricos}

Nas Tabela 57 a 59 , onde estão apresentados os resultados das análises da variância dos dados referentes aos testes para avaliação das relações entre o teor de água e emergência das plântulas, observaram-se valores de F altamente significativos para os efeitos de potenciais hídricos sobre a emergência de plântulas dos lotes 1 e 2 e sobre a velocidade de emergência de plântulas dos lotes 1,2 e 3. Observaram-se também valores de $\mathrm{F}$ altamente significativos para os efeitos de teores de água sobre a emergência de plântulas do lote 1 e sobre a velocidade de emergência de plântulas dos lotes 1,2 e 3 .

Tabela 57. Valores de F obtidos nas análises da variância dos dados referentes ao estudo das relações entre o teor de água das sementes do lote 1 e emergência das plântulas sob a influência de diferentes potenciais hídricos do substrato.

\begin{tabular}{lcc}
\hline Causas da Variação & $\begin{array}{c}\text { Emergência das Plântulas } \\
(\%)\end{array}$ & $\begin{array}{c}\text { Indice de Velocidade } \\
(\%)\end{array}$ \\
\hline Potenciais (H) & $14.9549^{* *}$ & $35.2649^{* *}$ \\
Teores de água (A) & $7.0417^{* *}$ & $6.6678^{* *}$ \\
HX A & $0.4028^{\text {ns }}$ & $0.5435^{\text {ns }}$ \\
\hline
\end{tabular}

* significativo ao nivel de $5 \%$ de probabilidade; ${ }^{* *}$ significativo ao nivel de $1 \%$ de probabilidade ns não significativo 
Tabela 58. Valores de F obtidos nas análises da variância dos dados referentes ao estudo das relações entre o teor de água das sementes do lote 2 e emergência das plântulas sob a influência de diferentes potenciais hídricos do substrato.

\begin{tabular}{clcc}
\hline Lote & Causas da Variação & $\begin{array}{c}\text { Emergência das Plântulas } \\
(\%)\end{array}$ & $\begin{array}{c}\text { Indice de Velocidade } \\
(\%)\end{array}$ \\
\hline \multirow{2}{*}{2} & Potenciais (H) & $7.9048^{* *}$ & $12.8836^{* *}$ \\
& Teores de água (A) & $2.1221^{\text {ns }}$ & $3.5985^{*}$ \\
& H X A & $0.1674^{\text {ns }}$ & $0.7206^{\mathrm{ns}}$ \\
\hline
\end{tabular}

* significativo ao nível de $5 \%$ de probabilidade; ${ }^{* *}$ significativo ao nível de $1 \%$ de probabilidade ns não significativo

Tabela 59. Valores de F obtidos nas análises da variância dos dados referentes ao estudo das relações entre o teor de água das sementes do lote 3 e emergência das plântulas sob a influência de diferentes potenciais hídricos do substrato.

\begin{tabular}{clcc}
\hline Lote & Causas da Variação & $\begin{array}{c}\text { Emergência das Plântulas } \\
(\%)\end{array}$ & $\begin{array}{c}\text { Indice de Velocidade } \\
(\%)\end{array}$ \\
\hline \multirow{3}{*}{3} & Potenciais $(\mathrm{H})$ & $2.6403^{\mathrm{ns}}$ & $7.7313^{* *}$ \\
& Teores de água (A) & $2.2194^{\mathrm{ns}}$ & $3.5460^{*}$ \\
& H X A & $0.2740^{\mathrm{ns}}$ & $0.1550^{\mathrm{ns}}$ \\
\hline
\end{tabular}

${ }^{*}$ significativo ao nivel de $5 \%$ de probabilidade; ${ }^{* *}$ significativo ao nivel de $1 \%$ de probabilidade ns não significativo 
A velocidade de emergência das plântulas provenientes das sementes do lote 1 foi superior sob potencial hídrico de $-0,04 \mathrm{MPa}$ e, não diferiu entre si sob os potenciais hídricos de $-0,10$ e $-0,20 \mathrm{MPa}$ (Tabela 61 ), para os três teores de água estudados. Além disso, a velocidade de emergência das plântulas provenientes dessas sementes do lote 1 , com menor teor de água $(90 \mathrm{~g} / \mathrm{kg})$, foi a mais prejudicada, embora não tenha diferido estatisticamente da velocidade de emergência das plântulas provenientes das sementes com $110 \mathrm{~g}$ de água $/ \mathrm{kg}$.

A velocidade de emergência das plântulas provenientes das sementes do lote 2, não diferiu sob os potenciais hídricos de $-0,04 ;-0,10$ e -0,20 MPa (Tabela 61), para os três teores de água estudados. Notou-se que as plântulas sob potencial hídricos de $-0,40 \mathrm{MPa}$ apresentaram uma restrição do desenvolvimento, fato semelhante ao observado por SÁ (1987). Além disso, a velocidade de emergência das plântulas provenientes dessas sementes do lote 2 , com menor teor de água $(90 \mathrm{~g} / \mathrm{kg})$, foi a mais prejudicada, embora não tenha diferido da velocidade de emergência das plântulas provenientes das sementes com $110 \mathrm{~g}$ de água $/ \mathrm{kg}$, de tal forma que o aumento do teor de água favoreceu a velocidade de emergência das plântulas; à semelhança do observado para o lote 1.

A velocidade de emergência das plàntulas provenientes das sementes do lote 3, não diferiu sob os potenciais hídricos de $-0,04$ e -0,10 MPa (Tabela 61), para os très teores de água estudados. Além disso, a velocidade de emergência das plântulas provenientes dessas sementes do lote 3 , com menor teor de água $(90 \mathrm{~g} / \mathrm{kg})$, foi a mais prejudicada, embora não tenha diferido estatisticamente da velocidade de emergência das plântulas provenientes das sementes com $110 \mathrm{~g}$ de água/kg; à semelhança do observado para os lotes 1 e 2 . 
Tabela 60. Velocidade de emergência de plântulas: valores médios obtidos para o lote 1 de sementes de soja do cultivar IAC-15, com teores de água ajustados, após exposição a diferentes potenciais hídricos, e coeficiente de variação.

\begin{tabular}{|c|c|c|c|c|}
\hline \multirow[t]{2}{*}{ Potenciais hídricos (MPa) } & \multicolumn{3}{|c|}{ Teores de água ( $\mathrm{g} / \mathrm{kg}$ de sementes) } & \multirow[b]{2}{*}{ Médias } \\
\hline & 90 & 110 & 130 & \\
\hline$-0,04$ & 5.80 & 6.23 & 7.04 & $6.35 \mathrm{a}$ \\
\hline$-0,10$ & 4.61 & 5.41 & 5.33 & $5.12 \mathrm{~b}$ \\
\hline$-0,20$ & 4.36 & 5.05 & 5.27 & $4.89 \mathrm{~b}$ \\
\hline$-0,40$ & 2.55 & 2.78 & 3.91 & $3.08 \mathrm{c}$ \\
\hline Médias & $4.33 \mathrm{~B}$ & $4.86 \mathrm{AB}$ & $5.38 \mathrm{~A}$ & \\
\hline C.V. $(\%)$ & 18.3 & & & \\
\hline
\end{tabular}

Letras minúsculaś: comparações entre médias dentro de cada coluna.

Letras maiúsculas: comparações entre médias dentro de cada linha.

Tabela 61. Velocidade de emergência de plântulas: valores médios obtidos para o lote 2 de sementes de soja do cultivar IAC-15, com teores de água ajustados, após exposição a diferentes potenciais hídricos, e coeficiente de variação.

\begin{tabular}{ccccc}
\hline Potenciais hidricos $(\mathrm{MPa})$ & \multicolumn{3}{c}{ Teores de água $(\mathrm{g} / \mathrm{kg}$ de sementes) } & \\
\cline { 2 - 4 } & 90 & 110 & 130 & Médias \\
\hline$-0,04$ & 4.73 & 4.74 & 4.82 & $4.76 \mathrm{a}$ \\
$-0,10$ & 3.31 & 4.55 & 4.20 & $4.02 \mathrm{a}$ \\
$-0,20$ & 3.58 & 4.43 & 5.31 & $4.44 \mathrm{a}$ \\
$-0,40$ & 2.24 & 2.51 & 2.99 & $2.58 \mathrm{~b}$ \\
\hline Médias & $3.46 \mathrm{~B}$ & $4.06 \mathrm{AB}$ & $4.33 \mathrm{~A}$ & \\
\hline C.V. (\%) & 26.9 & & & \\
\hline
\end{tabular}

Letras minúsculas: comparações entre médias dentro de cada coluna.

Letras maiúsculas: comparações entre médias dentro de cada linha. 
Tabela 62. Velocidade de emergência de plântulas: valores médios obtidos para o lote 3 de sementes de soja do cultivar IAC-15, com teores de água ajustados, após exposição a diferentes potenciais hídricos, e coeficiente de variação.

\begin{tabular}{|c|c|c|c|c|}
\hline \multirow[t]{2}{*}{ Potenciais hídricos (MPa) } & \multicolumn{3}{|c|}{ Teores de água ( $\mathrm{g} / \mathrm{kg}$ de sementes) } & \multirow[b]{2}{*}{ Médias } \\
\hline & 90 & 110 & 130 & \\
\hline$-0,04$ & 3.90 & 4.18 & 4.82 & $4.30 \mathrm{a}$ \\
\hline$-0,10$ & 2.90 & 3.43 & 4.14 & $3.49 \mathrm{ab}$ \\
\hline$-0,20$ & 2.49 & 2.94 & 3.01 & $2.81 \mathrm{~b}$ \\
\hline$-0,40$ & 2.52 & 2.65 & 3.23 & $2.80 \mathrm{~b}$ \\
\hline Médias & $2.95 \mathrm{~B}$ & $3.30 \mathrm{AB}$ & $3.80 \mathrm{~A}$ & \\
\hline C.V. (\%) & 28.3 & & & \\
\hline
\end{tabular}

Letras minúsculas: comparações entre médias dentro de cada coluna.

Letras maiúsculas: comparações entre médias dentro de cada linha.

A emergência das plântulas dos lotes 1 e 2, para os três teores de água estudados, não diferiu entre si sob os potenciais hídricos de -0,04; -0,10 e - $-0,20 \mathrm{MPa}$ e, foi superior ao potencial hídrico de -0,40 MPa (Tabelas 63 e 64). Notou-se, também, que para o lote 2 , a redução da disponibilidade hídrica afetou igualmente a velocidade e a emergência das plântulas.

Pela Tabela 63, pode-se, também, constatar que a emergência das plântulas provenientes das sementes do lote 1 , com menor teor de água $(90 \mathrm{~g} / \mathrm{kg})$, foi a mais prejudicada, embora não tenha diferido estatisticamente daquela apresentada pelas sementes com $110 \mathrm{~g}$ de água $/ \mathrm{kg}$, de tal forma que, o aumento do teor de água favoreceu a emergência das plântulas.

Para o lote 2 , a emergência das plântulas provenientes das sementes com menor teor de água $(90 \mathrm{~g} / \mathrm{kg})$ não diferiu significativamente daquela apresentada pelas sementes com 110 e $130 \mathrm{~g}$ de água $/ \mathrm{kg}$, embora o valor numérico das médias tenha revelado os beneficios do umedecimento das sementes (Tabela 64).

Pela Tabela 65 , pode-se constatar que a emergência das plântulas do lote 3 não diferiu entre si, à medida em que foi reduzido o potencial hídrico, para os très teores 
de água estudados. Além disso, a emergência das plântulas provenientes das sementes com menor teor de água $(90 \mathrm{~g} / \mathrm{kg})$ não diferiu significativamente da emergência das plântulas provenientes de sementes com 110 e $130 \mathrm{~g}$ de água $/ \mathrm{kg}$, embora o valor numérico das médias tenha revelado os beneficios do umedecimento das sementes, como também constatado para o lote 2 (Tabela 64).

Quando compararam-se valores obtidos de germinação e a emergência de plântulas, pode-se constatar que a maior germinação dos três lotes foi observada sob os potenciais hídricos de $-0,04$ e $-0,10 \mathrm{MPa}$. Além disso, observou-se que a maior e mais rápida emergência dos lotes 1 e 2 foram observadas sob os potenciais hídricos de -0,04; 0,10 e -0,20 MPa e para o lote 3, a mais rápida emergência das plântulas foi observada sob o potencial hídrico de $-0,04$ e $-0,10 \mathrm{MPa}$.

Para os três lotes, observou-se pequena diferença entre as médias de germinação (Tabelas 48 a 50) e de emergência de plântulas (Tabelas 63 a 65), sob os potenciais hídricos de $-0,04$ e $-0,10 \mathrm{MPa}$; porém, à medida em que aumentou a restrição hídrica, essas diferenças tornaram-se mais acentuadas, sendo que as médias de emergência superaram as de germinação, provavelmente, devido a alta incidência de plântulas anormais infeccionadas quando foi avaliada a germinação em substrato papel toalha (Tabelas 51 a 53). Estas observações diferiram das apresentadas por SÁ (1987) onde os valores de germinação, quando utilizou-se substrato umedecido com soluções de manitol, superaram os de emergência.

Além disso, a média de germinação e de emergência das plântulas, para os três teores de água estudados, foi superior no lote 1, de qualidade fisiológica superior aos outros dois, principalmente sob menores potenciais hídricos, concordando com SÁ (1987) que também verificou um desempenho superior de sementes mais vigorosas, principalmente quando ocorrem condições de deficiência hídrica. 
Tabela 63. Emergência de plântulas: valores médios (\%) obtidos para o lote 1 de sementes de soja do cultivar IAC-15, com teores de água ajustados, após exposição a diferentes potenciais hídricos, e coeficiente de variação.

\begin{tabular}{|c|c|c|c|c|}
\hline \multirow[t]{2}{*}{ Potenciais hidricos $(\mathrm{MPa})$} & \multicolumn{3}{|c|}{ Teores de água ( $\mathrm{g} / \mathrm{kg}$ de sementes) } & \multirow[b]{2}{*}{ Médias } \\
\hline & 90 & 110 & 130 & \\
\hline$-0,04$ & 80 & 88 & 96 & $88 \mathrm{a}$ \\
\hline$-0,10$ & 84 & 86 & 90 & $87 \mathrm{a}$ \\
\hline$-0,20$ & 74 & 88 & 92 & $85 \mathrm{a}$ \\
\hline$-0,40$ & 52 & 60 & 72 & $81 \mathrm{~b}$ \\
\hline Médias & $73 \mathrm{~B}$ & $81 \mathrm{AB}$ & $88 \mathrm{~A}$ & \\
\hline$\overline{C . V .(\%)}$ & 15.8 & & & \\
\hline
\end{tabular}

Letras minúsculas: comparações entre médias dentro de cada coluna.

Letras maiúsculas: comparações entre médias dentro de cada linha.

Tabela 64. Emergència de plântulas: valores médios (\%) obtidos para o lote 2 de sementes de soja do cultivar IAC-15, com teores de água ajustados, após exposição a diferentes potenciais hídricos, e coeficiente de variação.

\begin{tabular}{ccccc}
\hline Potenciais hídricos $(\mathrm{MPa})$ & \multicolumn{3}{c}{ Teores de agua $(\mathrm{g} / \mathrm{kg}$ de sementes) } & \\
\cline { 2 - 4 } & 90 & 110 & 130 & Médias \\
\hline$-0,04$ & 80 & 82 & 86 & $83 \mathrm{a}$ \\
$-0,10$ & 74 & 76 & 80 & $77 \mathrm{a}$ \\
$-0,20$ & 70 & 80 & 88 & $79 \mathrm{a}$ \\
$-0,40$ & 48 & 50 & 60 & $53 \mathrm{~b}$ \\
\hline Médias & $68 \mathrm{~A}$ & $72 \mathrm{~A}$ & $79 \mathrm{~A}$ & \\
\hline C..$(\%)$ & 22.9 & & & \\
\hline
\end{tabular}

Letras minúsculas: comparações entre médias dentro de cada coluna.

Letras maiúsculas: comparações entre médias dentro de cada linha. 
Tabela 65. Emergência de plântulas: valores médios (\%) para o lote 3 de sementes de soja do cultivar IAC-15, com teores de água ajustados, após exposição a diferentes potenciais hídricos, e coeficiente de variação.

\begin{tabular}{ccccc}
\hline Potenciais hídricos $(\mathrm{MPa})$ & \multicolumn{3}{c}{ Teores de água $(\mathrm{g} / \mathrm{kg}$ de sementes) } & \\
\cline { 2 - 4 } & \multicolumn{9}{c}{90} & 110 & 130 & Médias \\
\hline$-0,04$ & 64 & 64 & 66 & $65 \mathrm{a}$ \\
$-0,10$ & 50 & 64 & 68 & $61 \mathrm{a}$ \\
$-0,20$ & 58 & 64 & 70 & $64 \mathrm{a}$ \\
$-0,40$ & 46 & 52 & 54 & $51 \mathrm{a}$ \\
\hline Médias & $55 \mathrm{~A}$ & $61 \mathrm{~A}$ & $65 \mathrm{~A}$ & \\
\hline C.V. $(\%)$ & 25.9 & & & \\
\hline
\end{tabular}

Letras minúsculas: comparações entre médias dentro de cada coluna.

Letras maiúsculas: comparações entre médias dentro de cada linha.

\subsection{Considerações Gerais}

A análise geral dos resultados obtidos permitiu verificar que as sementes absorveram água de acordo com o padrão trifásico sob a influência tanto do teor inicial de água e qualidade fisiológica das sementes, como dos potenciais hídricos do substrato.

A velocidade de absorção das sementes dos três lotes, com menor teor de água $(90 \mathrm{~g} / \mathrm{kg})$, foi mais rápida principalmente nas primeiras horas. No entanto, no final do processo de absorção, tendeu a aproximar-se da mais úmidas (110 e $130 \mathrm{~g}$ de água $/ \mathrm{kg}$ ). Além disso, nas primeiras 4 horas do processo de absorção de água, as sementes do lote 2 , com menor teor de água, intumesceram mais rapidamente.

Em relação a qualidade fisiológica das sementes, a velocidade de absorção das sementes do lote 3 , de qualidade fisiológica inferior, foi mais rápida, principalmente, nas primeiras horas. No entanto, no final do processo de absorção, tendeu a aproximar-se daquela apresentada pelos lotes 1 e 2 .

Com a diminuição do potencial hídrico, para todos os teores e lotes estudados, houve uma redução da velocidade de absorção de água e, consequentemente, um aumento do período necessário para que as sementes apresentassem o teor de água suficiente para a emissão da raiz primária, ou seja, $500 \mathrm{~g} / \mathrm{kg}$. Além disso, sob diferentes 
potenciais hídricos, o aumento do teor de água das sementes dos três lotes proporcionou a diminuição da velocidade de absorção de água.

No estudo dos danos por embebição, através da detecção da liberação de íns na solução, constatou-se que o aumento do teor de água para 110 e $130 \mathrm{~g} / \mathrm{kg}$ proporcionou a diminuição da liberação de íons pelas sementes dos lotes 1 e 2 sob os diferentes potenciais hídricos estudados e, das sementes do lote 3, sob menor disponibilidade hídrica.

No estudo dos danos por embebição, através da ocorrência de sintomas de deterioração por 'umidade", constatou-se que o aumento do teor de água proporcionou diminuição da ocorrência de sintomas de deterioração por "umidade" nas sementes viáveis do lote 1 sob diferentes potenciais hídricos do substrato e, nas sementes viáveis do lote 2 sob menor disponibilidade hídrica. Para as sementes do lote 3 , o aumento do teor de água não interferiu na ocorrência de sintomas de deterioração por "umidade" nas sementes viáveis que, provavelmente, apresentavam-se com as membranas danificadas, sob os diferentes potenciais hídricos.

Quando comparou-se os dados obtidos na avaliação dos danos por embebição com os dados de germinação e emergència, pode-se constatar que o aumento do teor de água, para o lote 1 , de melhor qualidade fisiológica, provocou diminuição dos danos por embebição, avaliados tanto pela liberação de íons como pela ocorrência de sintomas de deterioração por "umidade" e favoreceu a germinação e emergência sob os diferentes potenciais hídricos.

Para o lote 2, o aumento do teor de água diminuiu os danos por embebição avaliados pela liberação de íons sob os diferentes potenciais hídricos e pela ocorrência de sintomas de deterioração por "umidade" sob menor diponibilidade hídrica e tendeu a favorecer a germinação e emergência. No entanto, para o lote 3, o aumento do teor de água, também, tendeu a favorecer a germinação e emergência, porém não interferiu na ocorrència de sintomas de deterioração por "umidade" e na liberação de ions sob plena disponibilidade hídrica. Desta forma, o lote 1, de melhor qualidade, sofre mais com o menor teor de água das sementes. 


\section{CONCLUSÕES}

A análise dos dados e interpretação dos resultados permitiram as seguintes conclusões:

1. Existe efeito da qualidade fisiológica das sementes no desempenho sob influência de potenciais hídricos deficitários no substrato.

2. Para os potenciais hídricos estudados, o aumento do teor inicial de água das sementes contribui para a diminuição da velocidade de absorção de água e permite atenuar os danos por embebição, podendo favorecer a germinação e a emergência de plântulas, em função da qualidade fisiológica das sementes.

3. A germinação e a emergência estão diretamente relacionadas à disponibilidade hídrica do substrato. 


\section{REFERÊNCIAS BIBLIOGRÁFICAS}

ABDUL-BAKI, A.A. Biochemical aspects of seed vigour. HortScience, Alexandria, 15 (6):765-71, 1980 .

ABDUL-BAKI, A.A. \& ANDERSON, J.D. Physiological and biochemical deterioration of seeds In: KOZLOWSKI, T.T., ed. Seed biology. New York, Academic Press, 1972. v.2, p. 283-315.

ABDUL-BAKI, A.A. \& BAKER, J. Are changes in celular organelles or membranes related to vigour loss in seed? Seed Science and Technology, Zurich, 1: 89-125, 1973.

ARMSTRONG, H. \& McDONALD, M.B. Effects of osmocoditioning on water uptake and electrical conductivity in soybean seeds. Seed Science and Technology, Zurich, 20: 391-400, 1992.

ASHWORTH, E.N. \& OBENDORF, R.L. Imbibitional chilling injury in soybean axes: relationship to stelar lesions and seasonal environments. Agronomy Journal, Madison, 72: 923-8, 1980.

ASSOCIATION OF OFFICIAL SEED ANALYSIS. Seed Vigor Test Committee. Seed vigor testing handbook. Lincoln, 1983. 28p. (AOSA. Contribution, 32). 
BARROS, A.S. R. Testes para avaliação rápida da viabilidade e do vigor de sementes de soja (Glycine max (L.) Merrill). Piracicaba, 1988. 140p. (Mestrado - Escola Superior de Agricultura "Luiz de Queiroz"/ USP).

BECWAR, M.R.; STANWOOD, P.C.; ROS, E.E. Dehydration effects on imbibition leakage from desiccation-sensitive seeds. Plant Physiology, Rockville, 69: 1132-5, 1982.

BEDI, S. \& BASRA, A.H. Chilling injury in germination seeds: basic mechanisms and agricultural implications. Seed Science Research, Wallingford, 3: 219-29, 1993.

BEECROFT, P. \& LOTT, J.N.A. Identification of sites of $\mathrm{K}$ leakage from imbibing seeds and grains. Seed Science Research, Wallingford, 3: 105-10, 1993.

BEWLEY, J.D. \& BLACK, M. Seeds; physiology of development and germination. New York, Plenum Press, 1985. 367p.

BRADFORD, K.J. Manipulation of seed water relations via osmotic priming to improve germination under stress conditions. HortScience, Alexandria, 21(5): 1105-12, 1986.

BRADNOCK, W.T. \& MATTHEWS, S. Assessing field emergence potential of rinkled-seeded peas. Horticultural Review, Westport, 10: 50-8, 1970.

BRAMLAGE, W.J.; LEOPOLD, A.C.; PARRISH, D.J. Chilling stress to soybean during imbibition. Plant Physiology, Rockville, 61:525-9, 1978.

BRASIL. Ministério da Agricultura. Regras para análise de sementes. Brasilia, Depto. Nac. Prod. Veg., 1992. 365 p.

BRUGGINK, H.; KRAAK, H.L.; BEKENDAM, J. Some factors affecting maize (Zea mays L.) cold test results. Seed Science and Technology, Zurich, 19: 15-23, 1991.

CALERO, E.; WEST, S.H.; HINSON, K. Water absorption of soybean seed and associated causal factors. Crop Science, Madison, 21(6): 926-33, 1981. 
CARDWELL, V.B. Seed germination and crop production. In: TESAR, M.B., ed. Physiological basis of crop growth ad development. Madison, ASA, 1984. cap.3, p. 53-92.

CARVALHO, N.M. A secagem de sementes. Jaboticabal, FUNEP, 1994. 167p.

CARVALHO, N.M. \& NAKAGAWA, J. Sementes: ciência, tecnologia e produção. 3.ed Campinas, Fundação Cargill, 1988. 424p.

COLLIS-GEORGE, N. \& MELVILLE, M.D. Water absorption by swelling seeds. II. Surface condensation boundary condition. Australian Journal of Soil Research, East Melbourne, 16: 291- 310, 1978.

COPELAND, L.O. Seed science and technology. 2.ed. Minneapolis, Burgess Publ., 1976. $369 \mathrm{p}$.

COSTA, J.A. \& MARCHEZAN, E. Características dos estados de desenvolvimento da soja. Campinas, Fundação Cargill, 1982. 30p.

COSTA, N.P. \& MARCOS FILHO, J. Temperatura e pré-condicionamento de sementes de soja para o teste de tetrazólio. Scientia Agricola, Piracicaba, 51(1): 158-68, 1994.

COSTA, N.P; FRANÇA NETO, J. de B; OLIVEIRA, M.C.N. Padronização de testes de vigor para sementes de soja. In: EMPRESA BRASILEIRA DE PESQUISA AGROPECUÁRIA. Centro Nacional de Pesquisa de soja. Resultado de pesquisa de soja 1986/1987. Londrina, 1988. p.358-59.

DELOUCHE, J.C. Planting seed quality. Mississippi, Mississippi State University/ Agricultural Experiment Station, 1969. (Paper, 1721). 
DELOUCHE, J.C. \& BASKIN, C.C. Accelerated aging technic for predicting the relative storability of seed lots. Seed Science and Technology, Zurich, 1: 427-52, 1973.

DELTOUR, R. \& JACQWARD, A. Relation between water stress and DNA synthesis during germination of Zea mays L. Annals of Botany, London, 38: 529-34, 1974.

DIAS, D.C.F.S. Teste de condutividade elétrica e de lixiviação de potássio para avaliação do vigor de sementes de soja (Glycine max (L.) Merrill). Piracicaba, 1994. 136p. (Doutorado - Escola Superior de Agricultura "Luiz de Queiroz"/ USP).

DUKE, S.H. \& KAKEFUDA, G. Role of the testa in precenting cellular rupture during imbibition of legume seeds. Plant Physiology, Rockville, 67: 449-56, 1981.

DUKE, S.H.; KAKEFUDA, G; HARVEY, T.M. Differential leakage of intracellular substances from imbibing soybean seeds. Plant Physiology, Rockville, 72: 919-24, 1983.

EIRA, M.T.S. Condicionamento osmótico de sementes de alface (Lactuca sativa L.); efeitos sobre a germinação e desempenho sob stresses hídrico, salino e térmico. Piracicaba, 1988. 90 p. (Mestrado - Escola Superior de Agricultura "Luiz de Queiroz"/ USP).

ELDER, R.H.; DELL'AQUILA, A.; MEZZNNA, M. SARASIN, A.; OSBORNE, J.D. DNA lipase in repair and replication in the embryo of rye, Secale cereale. Mutation Research, Amsterdan, 181: 61-71, 1987.

ELLIOTT, B. Construction of seed box for use in the accelerated. The NewsLetter of Association of Official Seed Analysts, Brunswicks, 56: 61-4, 1982.

ELLIS, R.H.; HONG, T.T.; ROBERTS, E.H. Effect of moisture content and method of rehydration on the susceptibility of pea seeds to imbibition damage. Seed Science and Technology, Zurich, 18: 131-7, 1990. 
FRANÇA NETO, J.B.; PEREIRA, L.A.G.; COSTA, N.P.; KRZYZANOWSKI, F.C.; HENNING, A.A. Metodologia de teste de tetrazólio em sementes de soja. Londrina, EMBRAPA/CNPSo, 1988. 60p. (EMBRAPA/ CNPSo. Documentos, 37).

FRATIN, P. ; MARCOS FILHO, J. Teste de envelhecimento de sementes de soja em "gerbox" adaptados. In: SEMINÁRIO NACIONAL DE SOJA, 3., Campinas, 1984. Anais . Londrina, EMBRAPA/CNPSo, 1984. p.1008-16.

FU, J.R.; LU, X.H.; CHEN, R.Z.; ZHANG, B.Z; LIU, Z.S.; LI, Z.S.; CAI, D.Y. Osmoconditioning of peanut (Arachis hypogaea L.) seeds with PEG to improve vigour and some biochemical activities. Seed Science and Technology, Zurich, 16: 197-212, 1988.

GANGULI, S.; SEN-MANDI, S. Some physiological differences between naturally and artificially aged wheat seeds. Seed Science and Technology, Zurich, 18(3): 507-14, 1990.

HEATHERLY, G.L. ; RUSSEL, W.J. Effects of soil water potencial of two soil on soybean emergence. Agronomy Journal, Madison, 71: 980-2, 1979.

HEGARTY, T.W. Seed activation and seed germination under moistures stress. New Phytologist, London, 78: 349-59, 1977.

HENNING, A.A.; KRZYZANOWSKI, F.C.; FRANÇA NETO, J.B.; YORINORI, J.T. Tratamento de sementes de soja com fungicidas. Anuário Abrasem, Brasília, p. 8-10, 1992.

HEPBURN, H.A.; POWELL, A.A.; MATTHEWS, S. Problems associated with routine application of electrical condutivity measurements of individual seeds in the germination testing of peas and soybeans. Seed Science and Technology, Zurich, 12: $403-13,1984$. 
HERRERA, T. ; PETERSON, W.H.; COOPER, E.J.; PEPPER, H.J. Loss of cell constituentes on reconstitution of active dry yeast. Archives of Biochemistry and Biophysics, New York, 63: 131-43, 1956.

HEYDECKER, W. \& COOLBEAR, P. Seed treatments for improved performance; survey and attempted prognosis. Seed Science and Tecnhology, Zurich, 5(2): 353$425,1977$.

HEYDECKER, W.; HIGGINS, J.; GUILLIVER, R.I. Accelerated germination by osmotic seed treatment. Nature, London, 246: 42-4, 1973.

HEYDECKER, W.; HIGGINS, J.; TURNER, Y.J. Invigoration of seeds? Seed Science and Technology, Zurich, 3: 881-8, 1975.

HOBBS, P.R. \& OBENDORF, R.L. Interaction of initial seed moisture and imbibitional temperature on germination and productivity of soybean. Crop Science, Madison, 13: $664-7,1972$.

HOHLBERG, A. \& STANLEY, D.W. Hard-to-cook defect in black beans. Protein and starch considerations. Journal of Agricultural and Food Chemistry, Easton, 35: $571-6,1987$.

HSU, K.H.; KIN, C.J.; WILSON, L.A. Factors affecting water uptake by soybeans during soaking. Cereal Chemistry, Saint Paul, 60(3): .208-11, 1983.

HUNTER, J.L. \& ERICKSON, A.E. Relation of seed germination to soil moisture tension. Agronomy Journal, Madison, 44: 107-9, 1952.

ISHIDA, N.; KANO, H.; KOBAYASHI, T.; HAMAGUCHI, H.; YOHIDA, T. The relationship between imbibitional damage and initial water content of soybeans . Agricultural and Biological Chemistry, Tokyo, 52: 2771-5, 1988. 
KNYPL, J.S. \& KHAN, A.A. Osmoconditioning of soybean seeds to improve performance at suboptimal temperatures. Agronomy Journal, Madison, 73: 112-6, 1981.

KNYPL, J.S.; JANAS, K.M.; RADZIWONOWSKA-JOZWIAK, A. Is enhanced vigour in soybean (Glycine max) dependent on activation of protein turnover during controlled hydration of seeds? Physiologie Vegetale, Paris, 18(1): 157-61, 1980.

KUO, W.H.J. Delayed permeability of soybean seeds: characteristics and screening methodology. Seed Science and Technology, Wageningen, 17: 131-42, 1989.

LABOURIAU, L.G. A germinação das sementes. Washington, OEA, 1983. 174p. (Coleção de Monografias Científicas - Biológicas,24).

LARSON, L.A. The effect soaking pea with or without seed coats has on seedling growth. Plant Physiology, Lancaster, 43: 255-9, 1968.

LeDEUNFF, Y. Hydration des semences de pois (Pisum sativum). Seed Science and Technology, Zurich, 17: 471-83, 1989.

LEOPOLD, A.C. Temperature effects on soybean imbibition and leakage. Plant Physiology, Rockville, 65: 1096-8, 1980.

LIN, S.S. Alterações na lixiviação eletrolítica, germinação e vigor da semente de feijão envelhecida sob alta umidade relativa do ar e alta temperatura. Revista Brasileira de Fisiologia Vegetal, Londrina, 2(2): 1-6, 1990.

LOEFFLER, T.M., TEKRONY, D.M.; EGLI, D.B. The bulk condutivity test as an indicator of soybean seed quality. Journal of Seed Technology, East Lansing, 12(1): $37-53,1988$. 
LOOMIS, E.L. \& SMITH, D.E. The effect of artifficial aging on the concentration of $\mathrm{Ca}, \mathrm{Mg}, \mathrm{Mn}, \mathrm{K}$ and $\mathrm{Cl}$ in imbibiting cobbage seed. Journal of the American Society for Horticultural Science, Saint Joseph, 105: 647-50, 1980.

LOTT, J.N.A.; CAUDEK, V.; CARSON, J . Leakage of $\mathrm{K}, \mathrm{Mg}, \mathrm{Cl}, \mathrm{Ca}$ and $\mathrm{Mn}$ from imbibing seeds grains and isolated seed parts. Seed Science Research, Wallingford, 1: 229-33, 1991 .

LUZZATI, V. \& HUSSON, F. The structure of the liquid-crystalline phases of lipidwater systems. The Journal of Cell Biology. Stuttgart, 12: 207-19, 1962.

MARCOS FILHO, J. Germinação de sementes. In: SEMANA DE ATUALIZAÇÃO EM PRODUÇÃO DE SEMENTES, 1., Piracicaba, 1986. Campinas, Fundação Cargill, 1986. p.11-39.

MARCOS FILHO, J. Teste de envelhecimento acelerado. In: VIEIRA, R. D. \& CARVALHO, N.M. Testes de vigor em sementes. Jaboticabal, Funep, 1994. p.133- 49 .

MARCOS FILHO, J. \& VINHA, J.L. Teor de umidade da semente, condições de armazenamento e comportamento da soja (Glycine max (L). Merrill) no teste de envelhecimento rápido. O Solo, Piracicaba, 1: 21-6, 1980.

MARCOS FILHO, J.; CICERO, S.M.; SILVA, W.R. Avaliação da qualidade das sementes. Piracicaba, FEALQ, 1987. 230 p.

MARCOS FILHO, J.; FONSECA, M.C.B.; MASSOTTI, M.A. Teor de umidade da semente, e comportamento de soja, no teste de envelhecimento rápido. Pesquisa Agropecuária Brasileira, Brasília, 13(3): 11-6, 1978.

MARCOS FILHO, J.; CARVALHO, R.V.; CÍCERO, S.M.; DEMÉTRIO, C.G.B. Qualidade fisiológica e comportamento de sementes de soja (Glycine max (L.) 
Merrill) no armazenamento e no campo. Anais da Escola Superior de Agricultura "Luiz de Queiroz", Piracicaba, 42: 195-249, 1985.

MATTHEWS, S. \& POWELL, A.A. Environmental and physiological constraints on field performance of seeds. HortScience, Alexandria, 21(5): 1125-8, 1986.

MAYER, A.M. \& POLJALOFF-MAYBER, A. The germination of seeds. 3. ed. New York, Pergamon Press, 1975. 210 p.

McDONALD Jr., M.B.; VERTUCCI, C.W.; ROOS, E.C. Seed coat regulation of soybean imbibition. Crop Science, Madison, 28: 987-92, 1988a.

McDONALD Jr., M.B.; VERTUCCI, C.W.; ROOS, E.C. Soybean seed imbibition: water absorption by seed parts. Crop Science, Madison, 28: 993-7, 1988b.

McGINNIES, W.J. Effects of moisture stress and temperature on germination of six range grasses. Agronomy Journal, Madison, 52: 159-63, 1960.

MICHEL, B.E. \& KAUFMANN, M.R. The osmotic potencial of polyethylene glicol 6000. Plant Physiology, Rockville, 51(5): 914-6, 1973.

MUNDEL, H.H. Emergence and vigor of soybean in relation to initial seed moisture and soil temperature. Agronomy Journal, Madison, 78: 765-9, 1986.

MURPHY, J.B. \& NOLAND, T.L. Temperature effects on seed imbibition and leakage mediated by viscosity and membranes. Plant Physiology, Rockville, 69: 428-31, 1982

OBENDORF, R.L. \& HOBBS, P.R. Effect of seed moisture on temperature sensitives during imbibition of soybean. Crop Science, Madison, 10:563-6, 1970.

OLIVEIRA, J.O. de. Correlação entre a evolução de hexanal e de aldeídos totais, a lixiviação de íons e o potencial de germinação de sementes de soja (Glycine max (L.) Merrill). Viçosa, 1990. 79 p. (Mestrado - Universidade Federal de Viçosa). 
PANDEY, D.K. Priming induced repair in french bean seeds. Seed Science and Technology, Zurich, 16: 527-32, 1988.

PANDEY, D.K. Priming induced alleviation of the effects of natural ageing derived selective leakage of constituents in French bean. Seed Science and Technology, Zurich, 17: 391-7, 1989.

PARMAR, M.T. \& MOORE, R.P. Carbowax 6000, mannitol and sodium chloride for simulating drought conditions in germination studies of corn (Zea mays L.) of strong and weak vigor. Agronomy Journal, Madison, 60: 192-5, 1968.

PARRISH, D.J. \& LEOPOLD, A.C. Transient changes during soybean imbibition. Plant Physiology, Rockville, 59: 1111-5, 1977.

PARRISH, D.J. \& LEOPOLD, A.C. On the mechanism of ageing in soybean seeds. Plant Physiology, Rockville, 61: 365-8, 1978.

PASHA, M.R. \& DAS, R.K. Quick viability test of soybean seed by using tetrazolium chloride. Seed Science and Technology, Zurich, 10(2): 651-5, 1982.

PEREIRA, L.A.G.; COSTA, N.; ALMEIDA, A.M.R.; SILVA, C.M.; SARTORI, J.F. Efeito da interação de tratamento químico de sementes de soja e níveis de vigor. Fitopatologia Brasileira, Brasília, 6: 159-63, 1981.

PERL, M. \& FEDER, Z. Improved seedling development of pepper seeds (Capsicum annuum) by seed treatment for pregermination activies. Seed Science and Technology, Zurich, 9: 655-63, 1981.

PESKE, S.T. Germination and emergence of soybean seeds as related to moisture stress. Mississipi, 1983. 81p. ( $\mathrm{PhD}$ - Mississippi State University).

PESKE, S.T. \& DELOUCHE, J.C. Semeadura de soja em condições de baixa umidade do solo. Pesquisa Agropecuária Brasileira, Brasilia, 20(1): 69-85, 1985. 
PHILLIPS, R.E. Water diffusivity of germinating soybean, corn and cotton seed. Agronomy Journal, Madison, 60: 568-571, 1968.

POLLOCK, B.M. Imbibition temperature sensitivity of lima bean seeds controlled by initial seed misture. Plant Physiology, Rockville, 44: 907-911, 1969.

POWELL, A.A. Cell membrance and seed leachate conductivity in relation to the quality of seed for sowing. Journal of Seed Technology, East Lansing, 10(2): 81-100, 1986.

POWELL, A.A. \& MATTHEWS, S. The damaging effect of water on dry pea embryos during imbibition. Journal of Experimental Botany, Oxford, 29: 1215-29, 1978.

POWELL, A.A. \& MATTHEWS, S. The significance of seed coat damage in the production of high quality legume seeds. Acta Horticulturae, The Hague, 3: 22733,1981 .

POWELL, A.A.; OLIVEIRA, M.A.; MATTHEWS, S. The role of imbibition damage in determining the vigor of white and coloured seed lots of dwarf French bean (Phaseolus vulgaris). Journal of Experimental Botany, Oxford, 37: 716-22, 1986.

PRIESTLEY, D.A. \& LEOPOLD, A.C. Lipid changes during natural aging of soybeans seeds. Physiologia Plantarum, Copenhagen, 59: 467-70, 1983.

ROBERTS, E. H. Physiology of ageing and its aplication to drying and storage. Seed Science and Technology, Zurich, 9: 359-72, 1981.

ROCHA, V.S.; SEDIYAMA, T.; SILVA, R.F. da; SEDIYAMA, C.S.; THIEBAUT, J.T.L. Embebição de água e qualidade fisiológica de sementes de soja. Revista Brasileira de Sementes, Brasília, 6(2): 51-66, 1984. 
ROSSETTO, C.A.V. \& MARCOS FILHO, J. Metodologias de ajuste do grau de umidade e comportamento das sementes de soja no teste de germinação. Revista Brasileira de Sementes, Brasilia, (17), 1995. (No prelo)

ROWLAND. G.G. \& GUSTA, L.V. Effects fo soaking, seed moisture content, temperature and seed leakage on germination of faba beans (Vicia faba) and peas (Pisum sativum). Canadian Journal of Plant Science, Ottawa, 7: 401-6, 1977.

SÁ, M.E. Relações entre qualidade fisiológica, disponibilidade hídrica e desempenho de sementes de soja (Glycine max (L.) Merrill). Piracicaba, 1987. 147p. (Mestrado Escola Superior de Agricultura "Luiz de Queiroz"/ USP).

SALISBURY, F.B. \& ROSS, C.W. Plant physiology. 3.ed. Belmonte, Wadworth, $1985,540 \mathrm{p}$.

SCHOETTLE, A.W. \& LEOPOLD, A.C . Solutes leakage from artificially aged soybean seeds after imbibition. Crop Science, Madison, 24: 835-8, 1984.

SHIOGA, P.S. Controle da hidratação e desempenho das sementes de feijão (Phaseolus vulgaris L.). Piracicaba, 1990. 106p. Dissertação (Mestrado - Escola Superior de Agricultura "Luiz de Queiroz"/USP).

SILVA, W. R. Relação entre disponibilidade de água, tratamento fungicida e germinação de sementes de milho (Zea mays L.). Piracicaba, 1989. 113p. (Doutorado - Escola Superior de Agricultura “Luiz de Queiroz"/USP).

SIMON, E.W. Phospholipids and plant membrane permeability. New Phytologist; London, 73: 377-420, 1974.

SIMON, E.W. Early events in germination. In: MURRAY, D.R, ed. Seed physiology. London, Academic Press, 1984, v.2, cap.3, p.77-115. 
SIMON, E.W. \& MILLS, L.K. Imbibition, leakage and membranes. In: NOZZOLILLO, C.; LEA, P.J.; LOEWIS, F.A. Mobilization of reserves in germination, recent advances in phytochemistry. New York, Plenum Press, 1983. v. 17 , cap. 2 , p.9-27.

SIMON, E.W. \& RAJA-HARUN, R.M. Leakage during imbibition. Journal of Experimental Botany, Oxford, 23(77): 1076-85, 1972.

SINGER, S.J. \& NICOLSON, G.L. The fluid mosaic model of the structure of cell membranes. Science, New York, 175: 720-31, 1972.

STEUTER, A.A.; MOZAFAR, A.; GOODIN, J.R. Water potential of aqueous polyethylene glycol. Plant Physiology, Rockville, 67: 64-7, 1981.

SUTCLIFFE, J.F. As plantas e a água. 2. ed. São Paulo, EPU, 1980. 126p. (Temas de Biologia, 23).

SWANSON, B.G.; HUGHES, J.S.; RASMUSSEN, H.P. Seed microstructure: review of water imbibition in legumes. Food Microstructure, Chicago, 4: 115-24, 1985.

TAO, K.L.J. Factors causing variations in the conductivity test for soybean seeds. Journal of seed Technology, East Lansing, 3(1): 10-8, 1978.

TILDEN, R.L. \& WEST, S.H. Reversal of the effects of aging in soybean seeds. Plant Physiology, Rockville, 77: 584-6, 1985.

TOLEDO, F.F. \& MARCOS FILHO, J. Manual das sementes; tecnologia da produção. São Paulo, Agronômica Ceres, 1977. 224p.

VAN GENUCHTEN, M.T. A closed-form equation for predicting the hydraulic condutivity of insaturated soils. Annales Geophysicae, Paris, 3(5): 615-28, 1985. 
VERTUCCI, C.W. The kinetics of seed imbibition. In: CROP SCIENCE SOCIETY OF AMERICA. Seed moisture. Madison, CSSA, 1989. p.93-115. (CSSA. Special Publication, 14).

VERTUCCI, C.W. Towards a unifield hypothesis of seed aging. In: Proceedings of IV Internacional Workshop on Seeds: Basic and Applied Aspects of Seed Biology. Angers. França, 1992.

VERTUCCI, C.W. \& LEOPOLD, A.C. Dynamics of imbibition of soybean embryos. Plant Physiology, Rockville, 72: 190-3, 1983.

VERTUCCI, C.W. \& LEOPOLD, A.C. Bound water in soybean seed and its relations to respiration and imbibitional damage. Plant Physiology, Rockville, 75: 114-7, 1984.

VERTUCCI, C.W. \& LEOPOLD, A.C. Physiological activities associated eith hydration levels in seeds. In: LEOPOLD, A.C., ed. Membranes, metabolism and dry organims. Ithaca, Comstock Publ., 1986. p. 35-49.

VERTUCCI, C.W. \& LEOPOLD, A.C. Water binding in legume seeds. Plant Physiology, Rockville, 85: 224-31, 1987.

VIDAL - TORRADO, P. \& SPAROVEK, G. Mapa pedológico detalhado do Campus "Luiz de Queiroz". Piracicaba, ESALQ/Depto. de Ciência do Solo, 1993. (Esc. 1:10.000).

VIEIRA, R. D. Avaliação da qualidade fisiológica de sementes de quatorze cultivares de soja (Glycine max (L.) Merrill). Viçosa, 1980. 76 p. (Mestrado - Universidade Federal de Viçosa).

VIEIRA, R.D.; SEDIYAMA, T.; SILVA, R.F.; SEDIYAMA, C.S.; THIEBAUT, J.T.L. XIMENES, P.A. Estudo da qualidade fisiológica de sementes de soja (Glycine max (L.) Merrill), cultivar UFV-1, em quinze épocas de colheita. In: SEMINÁRIO 
NACIONAL DE PESQUISA DE SOJA, 2., Brasilia, 1981. Anais. Londrina, EMBRAPA/CNPSo, 1982. v.1, p.633-644. (EMBRAPA/CNPSo. Documentos, 1).

VILLELA, F.A. ; DONI FILHO, L.; SEQUEIRA, E.L. Tabela de potencial osmótico em função da concentração de polietilenoglicol 6000 e da temperatura. Pesquisa Agropecuária Brasileira, Brasilia, 26: 1957-68, 1991.

VILLIERS, T.A. \& EDGCUMBE, D.J. On the cause of seed deterioration in dry storage. Seed Science and Technology, Zurich, 3: 761-5, 1975.

VINDIOLA, O.L.; SUB, P.A.; HOSENEY, R.C. Accelerated developmente of the hardto-cook state in beans. Cereal Foods World, Saint Paul, 31: 538-51, 1986.

WARD, F.H. \& POWELL, A.A. Evidence for repair processes in onion seeds during storage at high seed moisture contents. Journal of Experimental Botany, Oxford, 34(140): 277-82, 1983.

WEBSTER, B.D. \& LEOPOLD, A.C. The ultraestructure of dry and imbibed cotyledons of soybean. American Journal of Botany, Baltimore, 64(10): 1286-93, 1977.

WILSON Jr, D.O. \& McDONALD Jr., M.B. The lipid peroxidation model of seed ageing. Seed Science and Technology, Wageningen, 14: 269-300, 1986.

WOODSTOCK, L.W. Seed imbibition: a critical period for successful germination. Journal of Seed Technology, East Lansing, 12(1): 1-15, 1988.

WOODSTOCK, L.W. \& TAO, K.J. Prevention of imbibition injury in low vigor soybean embrionic axes by osmotic control of water uptake. Physiologia Plantarum, Copenhagen, 51: 133-9, 1981.

WOODSTOCK, L.W. \& TAYLORSON, R.B. Soaking injury and its reversal with polyethylene glycol in relation to respiratory metabolism in high and low vigor soybean seeds. Physiologia Plantarum, Copenhagen, 53: 263-8, 1981. 
YAKLICH, R.W.; VIGIL, E.L.; WERGIN, W.P. Scanning electron microscopy of soybean coat. Scanning Electron Microscopy, Chicago, 2: 991-1000, 1984.

YAKLICH, R.W.; VIGIL, E. L.; WERGIN, W.P. Pore development and seed coat permeability in soybean. Crop Science, Madison, 26: 616-24, 1985.

YOUNG, J.A.; EVANS, R.A.; ROUNDY, B.; GREG, C. Moisture stress and seed germination. Washington, USDA, 1983. 40 p. (USDA. Agricultural Research Service, 36).

ZEEVAART, J.A.D. Abscisic acid content of spinach in relation to photoperiod and water stress. Plant Physiology, Rockville, 48: 86-90, 1971.

ZONTA, E.P.; MACHADO, A.D.; SILVEIRA, J.R., P. Sistemas de análise estatística para microcomputadores: SANEST. Pelotas, UFPel, 1984. (Registro SEI ${ }^{\circ}$ 06606-0, Categoria AO). 